\title{
LATE WISCONSINAN DEGLACIATION OF EMERALD BASIN, SCOTIAN SHELF
}

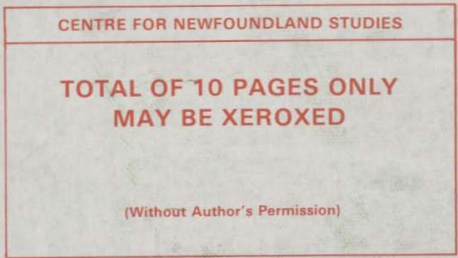

MICHAEL. ROBERT GIPP, B.SC.(Hons.) 


Canadian Theses Service Service des thèses canadiennes

Oltawa, Caneda

K1A ONA

The author has granted an irrevocable nonexclusive licence allowing the National Library of Canada to reproduce, loan, distribute or sell copies of his/her thesis by any means and in any form or format, making this thesis available to interested persons.

The author retains ownership of the copyright in his/her thesis. Neither the thesis nor substantial extracts from it may be printed or otherwise reproduced without his/her permission.
L'auteur a accordé une licence irrévocable et non exclusive permettant à la Bibliothèque nationale du Canada de reproduire, préter, distribuer ou vendre des copies de sa thèse de quelque manière et sous quelque forme que ce soit pour mettre des exemplaires de cette thèse à la disposition des personnes intéressées.

L'auteur conserve la propriété du droit d'auteur qui protège sa thèse. Ni la thèse ni des extraits substantiels de celle-ci ne doivent être imprimés ou autrement reproduits sans son autorisation. 


\title{
LATE WISCONSINAN DEGLACLATION OF EMERALD BASIN, SCOTIAN SHELF
}

\author{
BY \\ (C) Michael Robert Gipp, B.Sc. (Hons.)
}

A thesis submitted to the School of

Graduate Studies in partial fulfilment of

the requirements of the degree of

Master of Science

Department of Earth Sciences

Memorial University of Newfoundland

April, 1980

St. John's

Newfoundland 


\section{Abstract}

Emerald Basin is a glacially overdeepened basin located on the central Scotian Shelf, where Quaternary sediments form a thin veneer over Tertiary bedrock. Nineteen piston cores and 1200 line $\mathrm{km}$ of seismic data were obtained from the basin, from which seven acoustic facies were recognized: (i) Cambro-Ordivician metasediments (ii) Tertiary sediments (iii) Scotian Shelf Drift (till) (iv) acoustienlly stratified Emerald Silt (v) acoustically unstratified Fmerald Silt (vi) Lallnve Clay (vii) diffused gas. Six depositional sequences were recognized in the Emerald Silt and Lallave Clay facies, and were correlated with sediments recovered in piston cores. Depositional sequence 0 is a strongly stratified parkage which drapes over the Scotian Shelf Drift. It is correlated with stifr, unbioturbnted, slightly gravelly sandy muds, with no in situ molluses, and is characterised by an ice marginal foraminiferal assemblage. Depositional sequenee I drapes over depesitional secjuenee 0 and shows onlap on topographical highs. It is correlated with slightly gravelly muds, which are characterised by alternating bioturbated and unbioturbated hands. and monospecific molluscan and foraminiferal assemblages. Depositional sequuenen 2 asymmetrically drapes over and onlaps onto depesitional sequenee 1, and is correlated with bioturbated, slighty gravelly muds, with momesperific mollusean and foraminiferal assemblages. Depositional secquence 3 infills the basin deepses, crosionally truncating reflections of depositional sequenes 2 . It is correlated with bioturbated muds which are chararterised by a monesperific foraminiforal assemblage and a slightly diverse mollusean assemblage. Depesitional seupenen 1 drapes over the erosional upper surface of depesitional serpuener 3 , and is rorrelated with bioturbated muds which are characterised by a divere molluscan nssimblage. Depositional sequence 5 onlaps onto drpositional sequence 4 , infilling the brsin deeps, and is correlated with soft, bioturbated sandy sults, which are clinacterived by diverse molluscan and foraminiferal assemblages.

The present day seafloor in Emerald Basin is marked by small gas escape structures intepreted as porkmarks. Buried pockmneds are observed in tepositionnl sequences 4 and 5. Buried iceberg scours are observed on the upper surface of 
depositional sequence 0 , and within depositional sequences 1 and 2. Small ridges, interpreted as "lift-off" moraines, are formed on the upper surface of the Scotian Shelf Drift, and are oriented transverse to ice flow directions during glacial retreat. Wedge-shaped, acoustically unstratified features, interpeted as till tongues, are rooted in moraines on the basin flanks, and were deposited simultaneously with depositional sequences 0,1 , and 2 .

Detailed interpretation of the seismic and core data suggest that glacial ice advanced across Emerald Basin, reaching the shelf edge at approximately 24 ka. Melting of the ice sheet resulted in deglaciation of Emerald Basin at $17.5 \mathrm{kB}$, by liftoff of the grounded ice sheet to form a floating ice shelf of 10-100 yr duration. Sediment beneath the ice shelf was primarily supplied by subglacial meltwater streams. Prior to lift-off, till was squeezed into basal crevasses in the ice to form features known as "lift-off" moraines. The ice shelf calved at approximately 17.4 ka, causing intense scouring of the seafloor by in situ icebergs, and isolating ice rises on the banks surrounding Emerald Basin. These ice rises disintegrated rapidly, except for the rise on Emerald Bank, which contributed sediment to Emerald Basin until $12 \mathrm{ka}$. Sediment was primarily supplied by subglacial meltwater, and deposited out of suspension, except near the ice margin, where ice rafting and gravity now mechanisms were important. Iceberg scouring occurred until about 14 ka. The main ice margin remained on the northern flank of the basin until $15.4 \mathrm{ka}$, at which time it retreated landward. A widespread erosive event, caused by stormdriven currents, occurred at 13 ka. Rain-out from suspended sediment plumes was the dominant depositional mechanism until $12 \mathrm{ka}$. LaHave Clay is primarily derived from inner shelf sediments reworked by rising sea level. Storm-generated currents have created an erosional surface at the present day seafloor around the flanks of the basin. 


\section{Acknowledgements}

Financial support for this work was provided by NSERC funding to Dr. A. E. Aksu and Dr. D. J. W. Piper, and by Memorial I'niversity of Newfoundland (Graduate Student Fellowship. Bursary). Most field expenses were met by the Geological Survey of C'anada using funds from the Panel on Energy Rresearch and Devilopment (D. J. W: Piper) and the Frontier Cienseinene l'rogram (k. Moran)

1 would like to thank A. Aksu and D. Piper for supervision of this thems, and for advice offered during its completion. This work has benefited from diseumms wh G. Fader, L. King, H. Josenhans, P. Mudie, D). Cirant, (; Qunlan, and i Marho

Inpublished data is made available by K. Muran. I. Mayer. I) Secoll, and P. Mudie, for which I am grateful. I am also indlobted to K Howells. A. Mrkay. and D. Bidgood of the Nova Seotis Remeareh Foumdation corporatum for provulueg me with access to NSIRFr'data.

I would alses like to thank the offiers and crew of the ('SS Iludsun fur exrellent seamanship and safe operation of the vessel during the collectoon of tata fur this thesis. Thanks are also due to (;. Standen. for operating the Iluntere uystrm. W. Leblane, for performing (oulter counter analyas; h Hulertson and $S$. Hart fur x-radiograph work, F. Cole. for molluse identifieations, and A. Milles, for providing me with coarse sand residues from foraminifral samples.

My fellow students on Decadence Alley have prouded, by turne, gixud tumes, rumir relief, and aggravation. Individuals who stand out in this regard are $h$ Ruy. E. Cumming. F. Perriello, T. IIsnes. R. Cirenier, $>$, and P. (ontrom. and ohido Lastly, I would like to thank my family for their continumd aupport during the Iat three long years. 


\section{Table of Contents}

Abstract

Acknowledgements ill

Table of Contents iv

List of Tables $\quad$ vi

List of Figures $\quad$ vii

1. Introduction $\quad 1$

1.1 Morphology of the Scotian Shelf 1

1.2 Previous work 1

1.3 Scientific objectives $\quad 6$

2. Methodology $\quad 7$

2.1 Seismic data collection

2.2 Core collection and sampling $\quad 12$

3. Definition of Seismic Units 17

3.1 Definition of Acoustic facies 18

3.2 Depositional Sequences $\quad 28$

3.3 Implications of thickness variability

4. Sedimentology $\quad 53$

4.1 Lithofacies definition $\quad$ 5i3

4.2 Coarse sand and gravel petrology

4.3 Grain-size analysis $\quad 62$

4.4 Sedimentary structures $\quad: 1$

5. Biological Data

5.1 Macrobenthos 01

5.2 Microlossils

5.2.1 Benthic foraminifera

5.2.2 Dinoflagellates 98

5.2.3 Pollen and spores $\quad 100$

6. Chronology and core correlation $\quad 102$

6.1 Correlation of cores to seismic records $\quad 102$

$\begin{array}{ll}\text { 6.2 Radiocarbon dates } & 102\end{array}$

6.3 Dating the acoustic stratigraphy 108

$\begin{array}{lr}\text { 7. Seismic Features } & 108\end{array}$

$\begin{array}{ll}\text { 7.1 Erosion features at the seafloor } & 108\end{array}$

7.2 Erosion features in depositional sequences 4 and $5 \quad$ III

7.3 Buried features in depositional sequences 1 and $2 \quad 117$

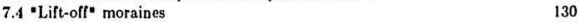

$\begin{array}{ll}7.5 \text { Till Tongues } & 1.40\end{array}$

8. Reconstruction of the late Wisconsinan environment in Emerald 151 Basin

8.1 Ice now directions $\quad 151$

$\begin{array}{ll}\text { 8.2 Lithofacies interpretation } & 158\end{array}$ 
8.3 Depositional sequence interpretation 150

๑. Conclusions 175

9.1 Summary 175

9.2 Suggestions for future research 177

References 178

I. Determining the average orientation of absurface population 180 of linear festures

I. Computer programs and subroutines 104

III. Seismic lines over core sites 208

IV. Dissected cumulative grain-size curves 


\section{List of Tables}

Table 2-1: Huntec DTS data collection 8

Table 2-2: NSRFC V-fin data collection 8

Table 2-3: Piston cores collected from Emerald Basin 15

$\begin{array}{ll}\text { Table 6-1: Shell AMS radiocarbon dates } & 104\end{array}$

Table 6-2: TOM radiocarbon dates $\quad 105$

Table 6-3: Chronology of the acoustic stratigraphy 107

Table 7-1: Seismic intersections and solution-pairs 123 


\section{List of Figures}

Figure 1-1: Location of Emerald Basin on the Sootian Shelf 2!

Figure 1-2: Physingraphy of Emorald basin and its surroumding hanks 3

Figure 2-1: Sicismic control map in

Figure 2-2: Sirsmic figures undex map 10

Figure 2-3: (ince location map)

Figure 3-1: Aroustic facims 1, 3, 1, nud b

Figure 3-2: dinu-ic facins 2, 3, 1, 6, and $;$

Figure 3-3: Types of orecurrencos of acouslie factess 31

Figure 3-4: Interealation betueen acoustic facies 3 and 1

Figure 3-5: Iafiral transition of acoustic facies 4 ant s

Figure 3-6: Distribution af acoustic facues 5 and b 2!

Figure 3-7: Distribution of aroustic farim $7 \quad 27$

Figure 3-8: Onlap onto the top of depositunal setjuenere 0

Figure 3-0: Regularly spaced reflections in depustional seppurner 0 30

Figure 3-10: Corplaten of peflection events betwern liunter lits and $\mathbf{3 1}$

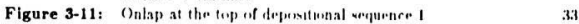

Figure 3-12: Asymmetrical dipesituon of depmitumat smpertice 2

Figure 3-13: Virosion at the base of depomitional serpuetiere a 3n

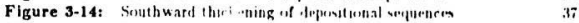

Figure 3-16: Virosion at the liase of dejomitional erouenee a

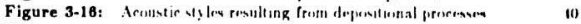

Figure 3-17: lsoparh map of depexiflutial sequencen 9

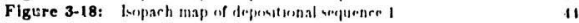

Figure 3-10: Isrparh map of dipustlonal wquence?

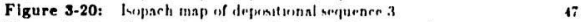

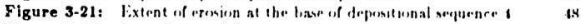

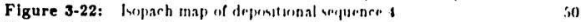

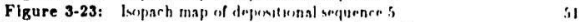

Figure 3-21: Extent of iforion at the firment day araflext i2

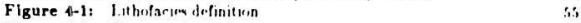

Figure 4-2: Core x-radugraphs is

Figure 4-3: Bntwion corn lithrifaries corpelatiens no

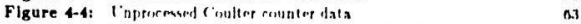

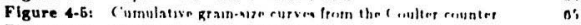

Figure 4-6: Mixing logenormal populatorins ot

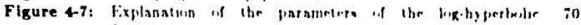

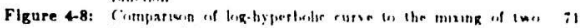

log-nutmal functums

Figure 4-9: Dicarted rumulative piain-uite rutrea is

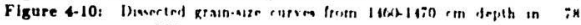
critr DOS 
Figure 4-11: Dissected sieve-hydrometer cumulative grain-size curves $\quad 81$

Figare 1-12: CM texture plots for log-normal components 83

Figure 4-13: Downcore variability of authigenic minerals and type of $\mathbf{8 6}$ bioturbation in core 004

Figure 4-14: Bioturbation structures and type of authigenic mineral present

Figure 4-16: Alternating bands of bioturbated and unbioturbated muds

Figure 5-1: Core x-radiographs of molluses and scaphopods

88

Figure 5-2:

Between core correlation of faunal assemblage boundaries

94

Figure 6-1:

Correlation of lithofacies to acoustic depositional sequences and AMS shell radiocarbon dates

Figure 7-1: Surficial pockmarks

98

103

Figure 7-2:

Figure 7-3:

Figure 7-4:

Figure 7-5:

Figure 7-6:

Figure 7-7:

Figure 7-8:

Figure 7-9:

Figure 7-10:

Figure 7-11:

Distribution of surficial pockmarks

100

Buried pockmarks

110

Distribution of buried pockmarks

112

Occurrence of pockmarks and sedimentation rate $\quad 115$

Buried iceberg scours

116

$\begin{array}{ll}\text { Distribution of buried iceberg scours } & 118\end{array}$

Distribution of scours on the eastern flank 110

Calculation of scour orientation

120

Plot of solution-pairs 124

Determining the significant solution from solution-pairs 125

$\begin{array}{ll}\text { Figure 7-12: Plot of the ignilicant solutions } & 127\end{array}$

Figure 7-13: Linear scour density plotted against depth 128

Figure 7-14: Topographical effects on scouring 131

Figure 7-15: Inferred iceberg drift trajectories 132

Figure 7-16: "Lift-off" moraines as they appear on a Huntec record 134

Figure 7-17: Distribution of "lift-off" moraines 135

Figure 7-18: "Lift-off" moraines as they appear on a V-fin record 136

Figure 7-10: Effect of seabed-receiver distance on the apparent 138 morphology of a small moraine

Figure 7-20: Apparent fish height plotted against known fish height

Figure 7-21:

Figure 7-22:

Figure 7-23:

Orientation of "lift-off" moraines in Emerald Basin

Longitudinal section of a till tongue

1.43

Transverse section of a till tongue

Distribution of till tongue $2 \quad 1.47$

Figure 7-25: Distribution of till tongues 3 and $4 \quad 1.48$

Figure 7-26: Distribution of till tongues 5 and $8 \quad 1-19$

Figure 8-1: Inferred directions of ice advance 152

Figure 8-2: Possible ice now directions during glacial retreat (no ice on 1.54 Emerald Bank)

Figure 8-3: Possible ice flow directions during glacial retreat (ice on 15i5 Emerald Bank)

Figure 8-1: Estimated position of the grounded ice margin at $17.5 \mathrm{ka} \quad 161$

Figure 8-5: Emerald Basin at $17.5 \mathrm{ka}$ 
Figure 8-6: Emerald Basin at $17 \mathrm{ka}$ and $18 \mathrm{ka} \quad 171$

Figure 8-7: Emerald Basin at $15 \mathrm{kn} \quad 172$

Figure 8-8: Emerald Bisin at $13 \mathrm{kn} \quad 17$

Figure 1-1: Derivation of equations used to calculate solutum-pairs

Figure 1-2: Resultant solution-pair when one sinsmic line is parallol to 1033 the orientation of the linear population

Figure III-1: Coressismic correlations 200

Figure IV-1: Disiected cumulative grain-size curver 21B 


\section{Introduction}

Emerald Basin is a glacially oversteepened basin located on the central Scotian Shelf $80 \mathrm{~km}$ to the south-southeast of Halifax, and is centered at $43^{\circ} 50^{\prime} \mathrm{N} 62^{\circ} 50^{\prime} \mathrm{W}$ (figure 1.1). It is $100 \mathrm{~km}$ long (SW to NE) and $45 \mathrm{~km}$ wide in the north, narrowing to $25 \mathrm{~km}$ in the southern half (figure 1.2).

\subsection{Morphology of the Scotian Shelf}

On the basis of bedrock and surface morphology, the Scotian Shelf is divided into three regions: (i) the inner shelf, underlain by Cambro-Ordovician rocks of the Meguma group, (ii) the central shelf, underlain by seaward dipping Cretacenus bedrock, and (iii) the outer shelf, ciaracterised by llat-topped banks separated by saddle-like depressions, and one large submarine canyon, the Gully (King, 1960; King et al., 1970; King and MacLean, 1976). The central shelf west of $61^{\circ} \mathrm{W}$ is characierised by basins, while to the east, it is characterised by a series of partially dissected valleys with the appearance of a former drainage system (King et al., 1970). Emerald Basin is the easternmost of three basins, which are located seaward of the boundary between the inner and central shelf, and are separated by isolated mesas. Although of subaerial origin, these basins have probably been oversteepened by Pleistocene glacial events (King et al., 1070).

\subsection{Previous work}

The Quaternary sediments on the Scotian Shelf form a relatively thin veneer over the bedrock, which largely controls the surface morphology (King, 1968; King and Fader, 1986). They are composed of five formations: Scotian Shelf Drift. Emerald Silt, Sambro Sand, LaHave Clay, and Sable Island Sand and Gravel (King and Fader, 1086). 


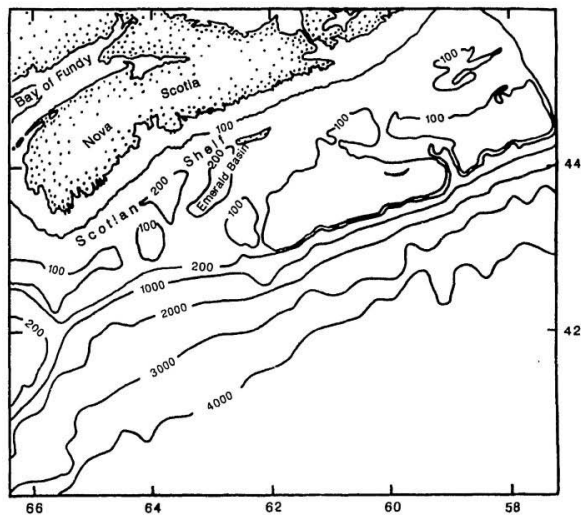

Figure 1.1. Bathymetric map of the Scotian Shelf, shewing the loration of limerald Basin. Contours in metres beiuw sea level. 


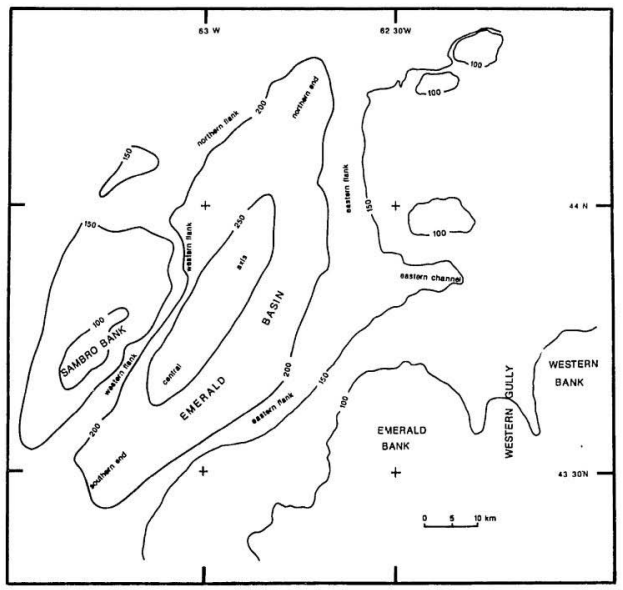

Figure 1.2. Physiographic map of Emerald Basin and the surrounding banks. Names in lower case letters represent the author's designation for different areas of Emerald Basin. 
Scotian Shelf Drift forms \& 10 to $15 \mathrm{~m}$ thick blanket over the erosional surface of the inferred Tertiary-Cretaceous sediment, except where eroded by the the late Wisconsinan marine transgression, but may reach $>100 \mathrm{~m}$ in moraines on the basin flanks (King, 1960). Wedge shaped till bodies, described as till tongues, are rooted in the distal side of moraines and on the flanks of the basins (King and Fader, 1986). On acoustic records, Scotian Shelf Drift appears as a dense mass of incoherent reflections, with limited penetration. It has a wide variation in grain size, from gravelly sand to mud with minor sand and gravel, and is interpreted as a till deposited from grounded ice (King and Fader, 1986).

Emerald Silt is an acoustically stratified unit which drapes over and interfingers Scotian Shelf Drift. On the basis of acoustic and sedimentological data, King and Fader (1986) divided Emerald Silt into three separate facies: facies $\mathbf{A}$, characterised by strong, closely spaced, coherent reflections and consisting of muds with alternating silt and clay layers, (ii) facies B, an onlapping facies characterised by medium to low amplitude continuous coherent reflections, consisting of wrakly to strongly banded silts and clays, and (iii) facies C, characterised by discontinuous coherent reflections.

LaHave Clay is an acoustically transparent unit, which fills in depressions in the underlying Emerald Silt. There are very weak continuous coherent reflections near the base of this unit. It is interpreted as material reworked from the inner shelf during the postglacial marine transgression (King and $F$ ader, 1988).

Regional reconstructions of late Wisconsinan glaciation allow for two possible 
states (i) maximum ice, grounded out on the continental shelf, with deglaciation controlled by marine processes and (ii) minimum ice, of limited offshore extent, with deglaciation controlled by terrestrial processes (Ives, 1978; Denton and Hughes, 1984; Prest, 1984). There is little doubt that glacial ice traversed the Scotian Shelf, but there is some question as to when it happened (Denton and Hughes, 188.4). Evidence for glacial ice on the Shelf at 20-26 ka exists on Banquereau (Amos and Knoll, 1887). Ice may have been present near the shelf edge at about $24 \mathrm{ka}$ (Mosher, 1887). Glacial tunnel valleys $>40 \mathrm{ka}$ beneath Sable Island Bank imply that the most intense glaciation on the Scotian Shelf occurred prior to the late Wisconsinan (Boyd et al., 1988; Scott et al., 1988).

In the early Wisconsinan, the Maritime provinces were covered by an ice shect with a uniform flow direction of NW-SF, with a terminus near the shelf margin (Grant and King, 1984). On the basis of total organic matter (TOM) radiocarbon dates, King and Fader (1986) inferred ages of 50-45 ka for Scotian Shelf Drift, 45-32 ka for Emerald Silt facies A, 32-15 ka for Emerald Silt facies B, and 15-0 ka for LaHave Clay. From these ages, King and Fader (1886) estimated sedimentation rates on the order of $1 \mathrm{~m} / \mathrm{kyr}$, from which they inferred the existence of a marine based ice sheet extending across the Scotian Shelf as early as $70 \mathrm{ka}$, which deposited Scotian Shelf Drift and Emerald Silt during a continuous recession starting at about $50 \mathrm{ka}$. Although non-glacial conditions may have existed in parts of New Brunswick and Nova Scotia in the mid-Wisconsinan (Grant and King, 1984), offshore basins remained covered by a floating ice shelf, depositing Emerald Silt facies $\mathbf{A}$, while the Scotian Shelf moraines remained in contact with grounded ice until $32 \mathrm{ka}$, whereupon the ice shelf disintegrated (King and Fader, 1986). Ice continued to 
recede from the Scotian Shelf, depositing Emerald Silt facies B, retreating entirely between 15 and $10 \mathrm{ka}$, after which LaHave Clay was deposited (King and Fader, 1986).

The chronology proposed by King and Fader (1986) is not supported by a TOM radiocarbon date of $\mathbf{1 5} \mathrm{ka}$ for Emerald Silt in Emerald Basin (Vilks and Rashid, 1976), nor by AMS shell radiocarbon dates obtained from central Emerald Basin of 14-15 ka for Emerald Silt facies B (Scott, pers. comm., 1989), nor by the oldest AMS shell radiocarbon date from Emerald Silt facies A of $17.4 \mathrm{ka}$ (Gipp and Piper, 1989).

\subsection{Scientific objectives}

The objectives of this thesis are: (i) to define the acoustic stratigraphy of the Emerald Silt and LaHave Clay in Emerald Basin (ii) to define the lithostratigraphy (iii) to characterise the acoustic architecture of the seismic depositional sequences within the Emerald Silt and LaHave Clay (iv) to establish a chronostratigraphy correlated with the acoustic stratigraphy using AMS shell radiocarbon dates (v) to determine the timing of the last deglaciation of Emerald Basin on the basis of acoustic architecture, sedimentary structures, small-scale seismic features, and palcontological data. 


\section{Methodology}

\subsection{Seismic data collection}

Over 1200 line $\mathrm{km}$ of high resolution seismic data were collected using (i) the Huntec deep-tow seismic (DTS) system (Hutchins et al., i976), with a 5 kJ source (930 km) (table 2.1), (ii) Nova Scotia Research Foundation Corporation (NSRFC) Vfin system (Bidgood, 1974) using either $180 \mathrm{~J}$ or $300 \mathrm{~J}$ sparkers (280 km) (table 2.2), and (iii) Ocean Resource Equipment (ORE) $3.5 \mathrm{kHz}$ transceiver (20 km) (figures 2.1, 2.2). Output from these systems was recorded on nineteen inch EPC recorders, with sweep speeds of either $250 \mathrm{~ms}$ or $500 \mathrm{~ms}$. Huntec data were collected with the fish towed at depths down to $70 \mathrm{~m}$ below sea level (b.s.l.). V-fin sparker data were collected with the fish towed at depths down to $250 \mathrm{~m}$ b.s.l. ORE $3.5 \mathrm{kHz}$ data were collected on CSS Dawson cruise 83-012 from a hull-mounted system. Transtex copies of the seismic records were produced with $50 \%$ reduction, from which blueline working copies were produced.

In marine acoustic profiling, a sound source and a receiver, or an array of receivers, are towed behind a moving ship. The sound source generates a pulse at fixed intervals, which is transmitted into and reflected back from layers in the sediment, detected by the receivers behind the ship, and recorded on a moving strip

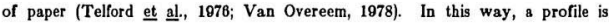
obtained, which has the appearance of a vertically exaggerated drawn geological section. As the depth to the reflectors is a function of time, some form of correction is needed to convert the time record to a geologic section (Telford et al., 1978; Van Overeem, 1978). 
Table 2.1: Huntec DTS data collection

\begin{tabular}{llrll}
\hline $\begin{array}{l}\text { Cruise } \\
\text { nuaber }\end{array}$ & Ship & $\begin{array}{c}\text { Amount } \\
\text { (1ine } \mathrm{kn})\end{array}$ & $\begin{array}{c}\text { time/Julian day } \\
\text { (start - finish) }\end{array}$ & Year \\
\hline 77-005 & CSS Hudson & 40 & $0400 / 105-0800 / 105$ & 1977 \\
Q-68 & CFAV Quest & 60 & $1130 / 041-2100 / 041$ & 1978 \\
S-24 & CNAV Sackvil10 & 120 & $1900 / 238-1930 / 239$ & 1978 \\
$79-011$ & CSS Hudson & 350 & $2200 / 157-0810 / 159$ & 1979 \\
$86-034$ & CSS Hudson & 150 & $0440 / 315-0530 / 317$ & 1986 \\
$87-003$ & CSS Hudson & 210 & $0200 / 094-1000 / 095$ & 1987 \\
\hline
\end{tabular}

Table 2.1. Cruises on which the fluntec data used in this thesis was colleeted. Data collected prior to 1986 was presented in King and Fader (1883).

Table 2.2: NSRFC V-fin data collection

\begin{tabular}{|c|c|c|c|c|}
\hline $\begin{array}{l}\text { Cruiee } \\
\text { number }\end{array}$ & Ship & $\begin{array}{c}\text { Anount } \\
(11 \mathrm{k} 0 \mathrm{~km})\end{array}$ & $\begin{array}{l}\text { time/Julian day } \\
\text { (start - finigb) }\end{array}$ & Year \\
\hline Br ${ }^{\prime} 73^{*}$ & y.y. Brandal & 40 & $0000 / 039-1845 / 040$ & 1973 \\
\hline $74-\mathrm{M18}$ & CHAV Sackville & 60 & $2130 / 093-0600 / 094$ & 1974 \\
\hline$K^{\prime} 75^{\prime}$ & CNAV Kapuskasing & 110 & $0000 / 103-1230 / 109$ & 1975 \\
\hline $86-035$ & CSS Darson & 70 & $0430 / 305-1130 / 305$ & 1986 \\
\hline
\end{tabular}

Table 2.2. (ruises on which the KSHFC: V-fin data usint in this thesis was collected.

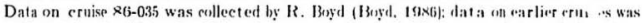
collected by D. Bidgood. V-fin dati wis made available by furmi-uien uf the Nora Seotia Research Foundation Corperation.

"Cruise numbers are unofficial designations used by the author. 


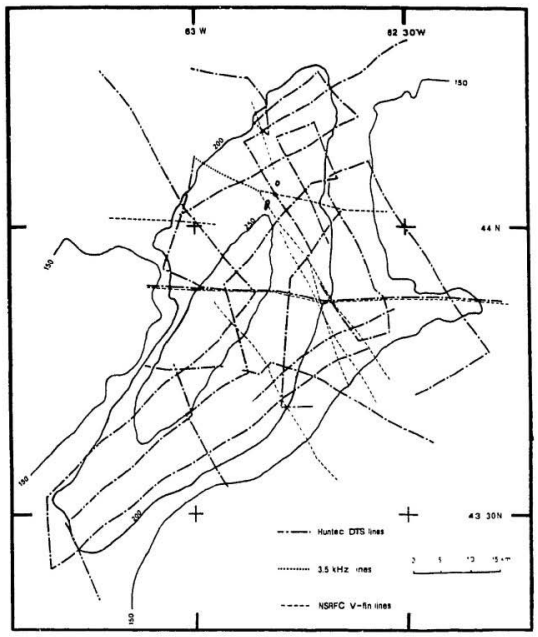

Figure 2.1. Seismic control map on present day bathymetry. Contours in in below sea level. 


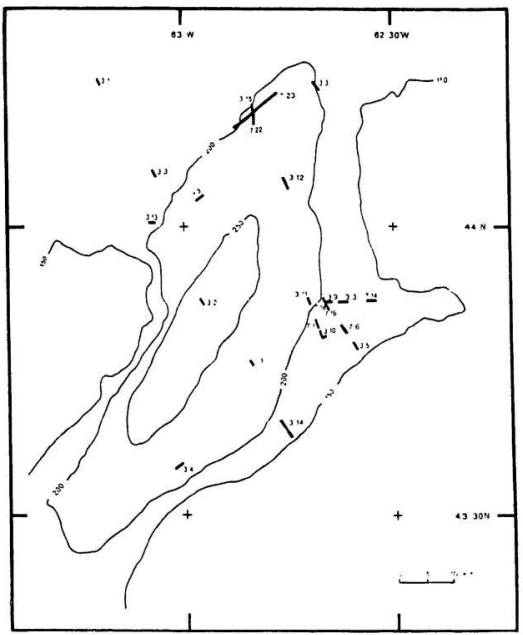

Figurn 2.2. Index map shou ing the position of illuatrated profile lay figure numbert 
Deep-towed systems have a number of advantages over surface-towed systems. Surface-towed systems are influenced greatly by ship noise, the vertical motion of the towing rehicle as well as the system, and the instrument-sea Moor separation is so great that the area insonified by the instrument is large, effectively averaging out features of small lateral extent (Bidgood, 1074; Sheriff, 1977). Because of the increased distance between the ship and the instrument, deep-towed systems are less affected by ship noise, and wave and swell motions are reduced at depth, as the cable dampens the vertical motion of the towing vehicle. Furthermore, by reducing the instrument-sea floor distance, the horizontal resolution of the dats is increased.

The acoustic source of the Huntec DTS is a broad-band $(800 \mathrm{~Hz}$ to $10 \mathrm{kHz})$ boomer (Hutchins at al, 1976). The boomer is an electromechanically driven aluminum plate which is repulsed when a capacitor bank is discharged through a potted wire coil (Orange et al, 1974; Telford et al, 1970). The plate is repelled from its start position so rapidly that a vacuum is left hehind it, imploding water into the evacuated volume (Teliord et al, 1076), and drawing the plate back to its rest position as the capacitor bank becomes fully discharged (Orange et al, 1974). As the lransmitting plate has a fixed aperature, the pulse shape varies with beam angle (MacIsaac and Dunsiger, 1877), and the acoustic signal has a high degree of repeatability (Hutchins et al, 1976). The Huntec DTS system is capable of achieving $100 \mathrm{~m}$ penetration into soft bottom sediments, and up to 33 metres in hard bottom sediments, with a vertical resolution of 6 to $8 \mathrm{~cm}$ achieved by processing (Hutchins et al, 1976), although the resolution actually obtainable is limited to the resolution of the EPC recorders used. 
The acoustic source of the NSRFC V-fin is a deep-towed sparker (Bidgood, 1974). A sparker operates by generating a spark between the two poles of a sparker tip. The potential is generated by discharging a capacitor bank into the tip, and a spark is generated. The spark vaporizes water creating an oscillating bubble. A seismic signal is thus created, but rather than consisting of a single impulse, the signal has the form of a damped oscillation. The portion of the signal after the first impulse is termed the bubble effect or pulse (Olhovich, 1964). The damping of the bubble pulse increases with depth such that at depths greater than $100 \mathrm{~m}$, it is considered to be negligible (Bidgood, 1874). The pulse length of a single-tip sparker source with a $200 \mathrm{~J}$ electrical input is about $1 \mathrm{~ms}$ at $100 \mathrm{~m}$ depth, and about $0.7 \mathrm{~ms}$ at $200 \mathrm{~m}$ depth (McKay and McKay, 1982).

The acoustic source for the ORE $3.5 \mathrm{kHz}$ sounder is a piezoclectric transducer, commonly referred to as a "pinger". A potential differenen is applivd arross a piczoelectric erystal, eausing a rapid distortion in the erystal which generates a seismic signal radiating from the instrument. When the signal returns to the instrument, it causes the crystal to experience a change in prossure which, in turn, generates a potential difference across the erystal. The potential difference so generated is a function of the strength of the returning signal.

\subsection{Core collection and sampling}

Four benthos piston cores (barrel length $\leq 12 \mathrm{~m}$, inner diameter $7.6 \mathrm{~cm}:$ ) and two long coring facility (LCF) piston cores (barrel length 20-30 m, inner diameter 10 cm) were collected for this study. Six additional Lehrigh piston oores (harral length

$\leq 12 \mathrm{~m}$, inaer diameter $10 \mathrm{~cm})$ and two additional $\mathrm{LC}(\mathrm{F}$ cores, rollected for 
geotechnical studies, were made available to the suthor. A total of nineteen piston cores have been collected in Emerald Basin since 1975 (figure 2.3: table 2.3).

Cores 021, 022, 023, and 025 were split, photographed, and described as outlined by Mudie et al. (1984) at the Atlantic Geoscience Centre (AGC). Colours were determined using a Munsel soil colour chart. Shells observed along the split core face were collected. identified, and were used to provide four AMS radiocarbon dates (Gipp and Piper, 1989). X-radiographs of core 022 and the upper five metres of core 023 were recorded as negative images, while x-radiographs of cores 021,025 , and the lower remaining section of core 023 were recorded as positive images on videotape. Cores 024,028, 029,030,031, and 032 were collected in order to correlate gestechnical properties with elastic properties obtained through the construction of s! : tetic seismograms (Moran, pers.comm.) Consolidation samples were taken prior to splitting. The cores were split, described, and photographed. The CORE velocimeter (Mayer, pers. comm., 1887) was used to determine the longitudinal velocity profile dowacore. Shear vane measurements, bulk density, and water content samples were collected.

LCF cores 002 and 006 were collected primarily for stratigraphic purposes, while cores 003 and 004 were collected for the seismic-geotechnical program (Manchester, 1988). All cores were processed on board: magnetic susceptibility, velocity, and shear strength profiles were determined; the cores were photographed and described; and samples were collected at variable intervals for bulk density, water content, and grain size determinations (Manchester, 1988). These grain size samples were analyzed by Maritime Testing using sieves and hydrometers (K. 


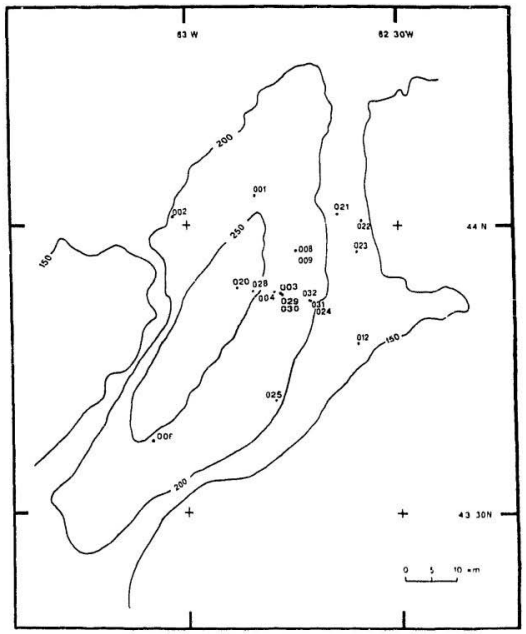

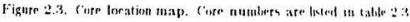


Table 2.3: Piston cores collected from Emerald Basin

\begin{tabular}{|c|c|c|c|c|c|}
\hline Core number & Latitude & Longtitude & $\begin{array}{c}\text { Mater } \\
\text { depth (m) }\end{array}$ & $\begin{array}{l}\text { Length } \\
\text { (in) }\end{array}$ & Designation \\
\hline $75-007-008$ & $43^{\circ} 57.4^{\prime} \mathrm{N}$ & $62^{\circ} 45.2^{\prime}$ 'T & 240 & 11.0 & $008^{1} \cdot 2$ \\
\hline 75-007-009 & $43^{\circ} 57.3^{\prime} \mathrm{N}$ & $62^{\circ} 45.2^{\prime}$ W & 244 & 6.0 & $009^{1}$ \\
\hline $77-002-020$ & $43^{\circ} 53.8^{\prime} \mathrm{N}$ & $62^{\circ} 53.1^{\prime} \mathrm{W}$ & 271 & 11.0 & $020^{2,3}$ \\
\hline 79-011-12p & $43^{\circ} 47.8^{\prime} \mathrm{N}$ & $62^{\circ} 36.3^{\prime} \mathrm{W}$ & 159 & 6.2 & $012^{4}$ \\
\hline $83-012-001$ & $44^{\circ} 03.34^{\prime} \mathrm{N}$ & $62^{\circ} 50.80^{\prime} \mathrm{W}$ & 245 & 10.31 & $001^{5}$ \\
\hline $86-034-021$ & $44^{\circ} 01.12^{\prime} \mathrm{N}$ & $62^{\circ} 39.00^{\prime} \mathrm{W}$ & 177 & 5.74 & 021 \\
\hline $86-034-022$ & $44^{\circ} 00.52^{\prime} \mathrm{N}$ & $62^{\circ} 35.63^{\prime} \mathrm{W}$ & 179 & 8.50 & 022 \\
\hline $86-034-023$ & $43^{\circ} 57.28^{\prime} \mathrm{N}$ & $62^{\circ} 36.52^{\prime} \mathrm{W}$ & 175 & 8.09 & 023 \\
\hline $86-034-024$ & $43^{\circ} 52.27^{\prime} \mathrm{N}$ & $62^{\circ} 42.93^{\prime} \mathrm{W}$ & 204 & 7.37 & 024 \\
\hline $86-034-025$ & $43^{\circ} 41.80^{\prime} \mathrm{N}$ & $62^{\circ} 47.65^{\prime} \mathrm{W}$ & 208 & 8.40 & 025 \\
\hline $86-034-028$ & $43^{\circ} 53.22^{\prime} \mathrm{N}$ & $62^{\circ} 50.77^{\prime} \mathrm{W}$ & 255 & 9.22 & 028 \\
\hline $86-034-029$ & $43^{\circ} 52.92^{\prime} \mathrm{N}$ & $62^{\circ} 46.97^{\prime} W$ & 233 & 9.20 & 029 \\
\hline $86-034-030$ & $43^{\circ} 52.90^{\prime} \mathrm{N}$ & $62^{\circ} 46.98^{\prime} \mathrm{W}$ & 233 & 9.05 & 030 \\
\hline $86-034-031$ & $43^{\circ} 52.17^{\prime} \mathrm{N}$ & $62^{\circ} 42.75^{\prime} \mathrm{W}$ & 207 & 8.36 & 031 \\
\hline $86-034-032$ & $43^{\circ} 62.15^{\prime} \mathrm{N}$ & $62^{\circ} 43.08^{\prime} W$ & 210 & 4.44 & $0 \div$ \\
\hline $87-003-002$ & $44^{\circ} 00.93^{\prime}$ & $63^{\circ} 02.04^{\prime} W$ & 215 & 16.86 & 002 \\
\hline $87-003-003$ & $43^{\circ} 52.90^{\prime} \mathrm{N}$ & $62^{\circ} 46.97^{\prime} \mathrm{W}$ & 232 & 12.09 & 003 \\
\hline $87-003-004$ & $43^{\circ} 53.10^{\prime} \mathrm{N}$ & $62^{\circ} 47.70^{\prime}$ & 235 & 19.27 & 004 \\
\hline $87-003-006$ & $43^{\circ} 37.56^{\prime} \mathrm{N}$ & $63^{\circ} 04.99^{\prime} \mathrm{W}$ & 247 & 16.67 & 006 \\
\hline
\end{tabular}

Table 2.3. Core location data for Emerald Basin cores. The first five digits in the core number refers to the cruise on which the core was collected. Cruise 8.3-012 was a CSS Dawson cruise; all other cruises in the table were on CSS Hudson. The "designation" column indicates the number used to refer to a particular core in the text. Cores 002, $006,021,022,023$, and 025 were collected for this thesis. Access to other cores from cruises 86-034 and 87-003 was by permission of K. Moran, L. Mayer, and the Bedford institute of Oceanography archives.
1 Vilks and Rashid (1976)
${ }^{3}$ Scott et al. ( 1984$)$
${ }^{5}$ Scotl, pers. comm. (1988)
${ }^{2}$ Mudie (1980)
${ }^{4}$ King and Fader (1986) 
Moran, pers. comm., 1988). Shells observed on the split core faces were collected for identification; some of these were used to obtain four AMS radiocarbon dates (Gipp and Piper, 1980). X-radiographs were recorded as positive images on videotape. Core 004 was sampled at $25 \mathrm{~cm}$ intervals for foraminifera and the lithology of the $>500 \mu \mathrm{m}$ fraction was identified. Samples $<1 \mathrm{~cm}^{3}$ were taken at variable intervals from cores 004 and 006 for grain-size measurements on the Coulter Counter (Coulter Electronics Inc., 1970). 


\section{Definition of Seismic Units}

An acoustic facies is defined on the basis of surface morphology, occurrence and intensity of internal reflections, magnitude of apparent acoustic contrast, and, in the case of outcropping units, acoustic reflectivity values (Belknap et al., 1986). Acoustic reflectivity values can be estimated from Huntec records (Parrot et al., 1980). There is no necessary stratigraphic relationship between acoustic facies: two acoustic facies may interfinger, or one may overlie another. The acoustic facies discussed in this chapter are defined in the same manner and based on the same criteria is those defined by King and Fader (1986), with the exception that Emerald Silt facies is not divided into two subfacies.

A seismic depositional sequence is defined as a relatively conformable succession of reflection events bounded at its top and base by unconformities or their correlative conformities (Mitchum et al., 1977). Therefore, seismic depositional sequences are stratigraphically significant: one sequence must everywhere either overlie or uncierlie another; two depositional sequences cannot interfinger. Depositional sequences are defined independently of acoustic facies, so that one depositional sequence might include more than one acoustic facies.

Seven acoustic facies are recognized on seismic records from Emerald Basin. Two of these may be correlated with pre-Quaternary units, and a third may be correlated with Scotian Shelf Drift. Six seismic depositional sequences are defined in the acoustic facies corresponding to the Emerald Silt and the LaHave Clay. 


\subsection{Definition of Acoustic facies}

Acoustic facies 1 (a.f. 1) is characterised by a high intensity return from an irregular surface (figure 3.1 ). This facies exhibits no internal reflections and surface reflectivity values are as high as $45 \%$. The occurrence of a.f. 1 is restricted to the area north of Emerald Basin, where Ordovician bedrock of the Meguma Group is known to occur (King and MacLean, 1970, 1976). This facies has been interpreted as Paleozoic bedrock of the Meguma Group (King and Fader, 1986).

Acoustic facies 2 (a.f. 2) is characterised by continuous, coherent, near horizontal internal reflections (figure 3.2 ). The intensity of the acoustic contrast between facies 2 and the overlying facies is apparently low. The upper surface of zcoustic facies 2 is commonly defined by the truncation of its internal reflections. Wherever a.f. 2 is identifiable, it is always stratigraphically the lowest facies present. Acoustic facies 2 has been interpreted as Mesozoic-Cenozoic bedrock of the Atlantic Coastal Plain sediments (King and Fader, 1986). This interpretation is supported by the occurrence of a.f. 2, which is restricted to areas south of the northern limit of Atlantic Coastal Plain sediments defined by King et al. (1070), and King and Maclean (1976). Additionally, the upper surface of a.f. 2 has been eroded (figure 3.2), as has the upper surface of the Atlantic Coastal Plain sediments (King et al., 1070).

Acoustic facies 3 (a.f. 3 )is characterised by a uniform pattern of incoherent reflections (figure 3.3). The upper surface of this facies is very irregular, and appears as a very strong, occasionally ringing, feflection on both Huntec and NSRFC records, with acoustic reflectivity valueg as high as $25 \%$. This facies occurs 


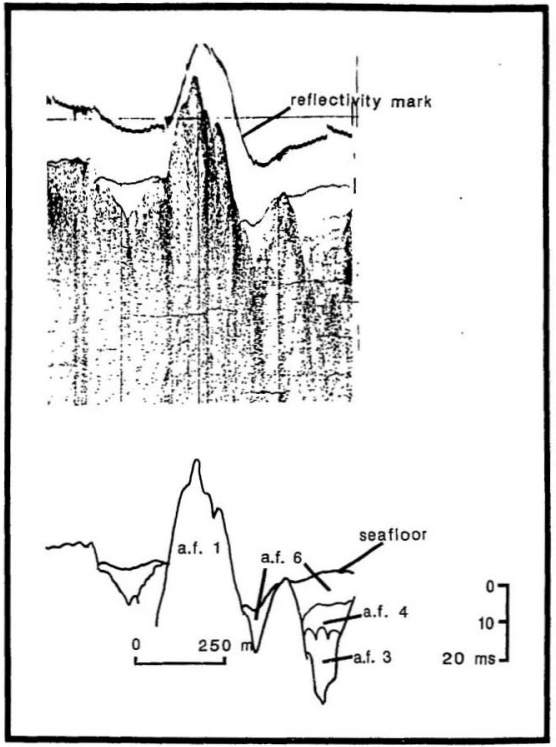

Figure 3.1. Huntec DTS profile trom the northern end of Emerald Basin, showing examples of acoustic facies 1, 3, 1, and 6 (discussed in text). 


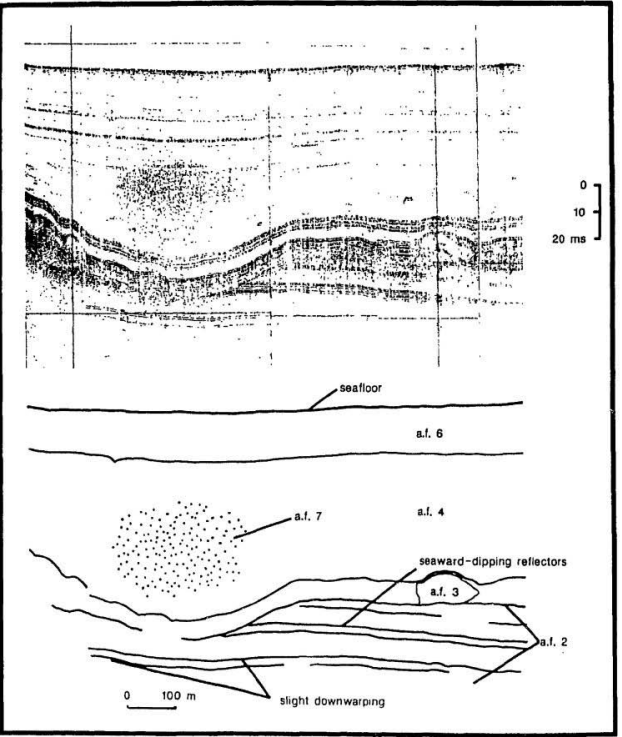

Figure 3.2. NSRFC V-fin sparker profile from the central axis of Emerald Haxin, ahesuing examples of acnustic facies 2, 3, 4, 6, and 7. Slight downwarping of gently dipping reflections in acoustic facies 2 beneath the ehannel in prebably a velerity anemaly Record appears by permisairs of NSRFC: 


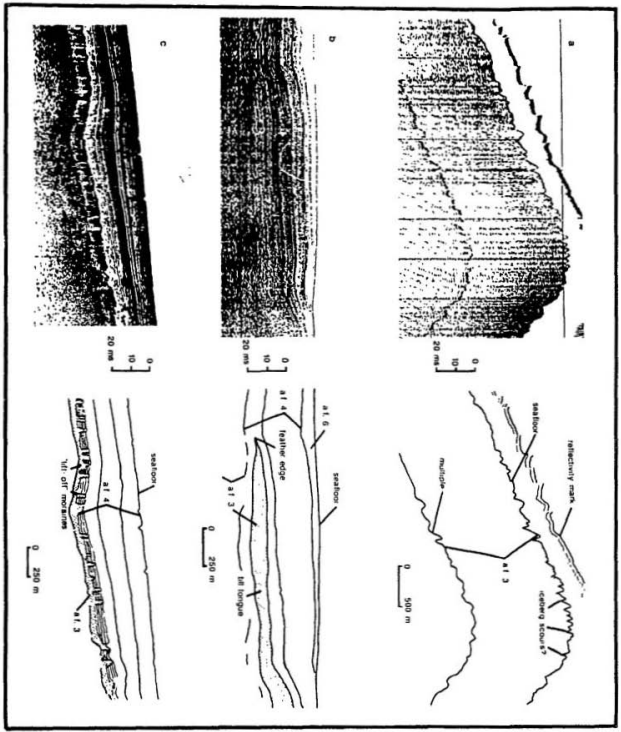

Fitzure 3.3. Huntee DTS profiles from Emerald Basin showing three types of occurrences ot acoustic facies 3 . From top to bot'nm. (a) a llank mound (b) a till tongue (c) •lift-ofr' moraines. 
in thick mounds at basin flanks, and as a relatively thin veneer within the basin itself. Acoustic facies 3 is also observed as wedges, called till tongues, which are acoustically continuous with the flank mounds (figure 3.3 ), and as small isolated hummocks, called "lift-off" moraines, which sidescan sonar records have demonstrated to be in the form of ridges (King and Fader, 1986). Acoustic facies 3 has been interpreted as Scotian Shelf Drift Formation, and includes sediments varying from gravelly sand to mud with minor sand and gravel (King and Fader, 1086).

Acoustic facies 4 (a.f. 4) is characterised by continuous, coherent internal reflections, usually appearing as distinct bands that are correlatable across the basin (figures $3.1,3.2$ ). The lowermost internal reflections conform to the morphology of the underlying unit, which is most commonly Scotian Shelf Drift, while the uppermost internal reflections display a more ponded style (cf. Barrie and Piper, 1982). Acoustic reflectivity values are $5-20 \%$. This facies is equivalent to the Emerald Silt facies described by King (1060), and the Emerald Silt facies A and B of King and Fader (1986). The author does not divide a.f. 4 into two subfacies because the primary differences between Emerald Silt facies A and B, while apparent on some Huntec records, arc not apparent on NSRFC records. Acoustic facies 1 is observed to intercalate with a.f. 3 on the north nank and locally in the southwest end of the basin (figure 3.4).

Acoustic facies 5 (a.f. 5) is characterised by discontinuous coherent reflections, grading laterally into a.f. 4 (figure 3.5 ). Acoustic facies 5 is restrict tod to the eastern flank of Emerald Basin (figure 3.6) and is equivalent to the Emerald Silt facies C, (King and Fader, 1988). 


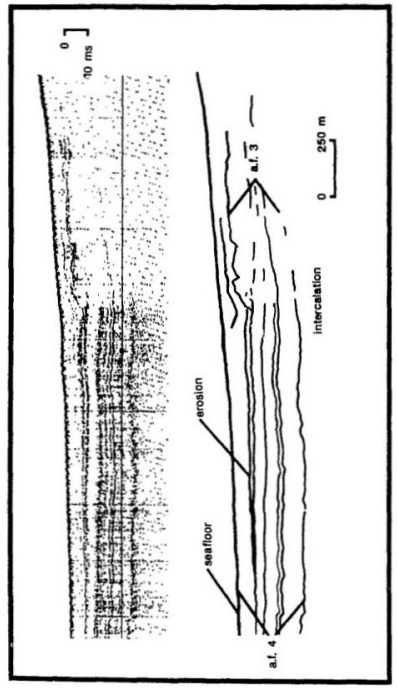

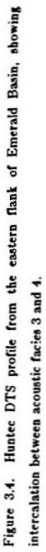




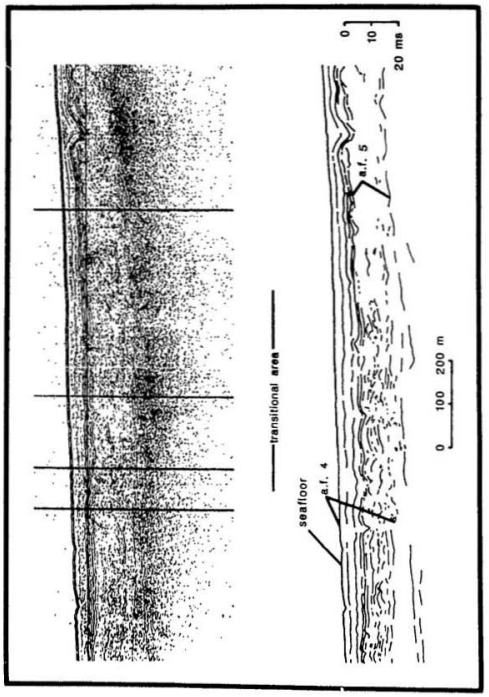

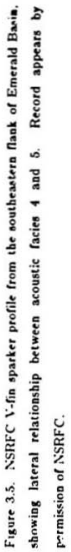




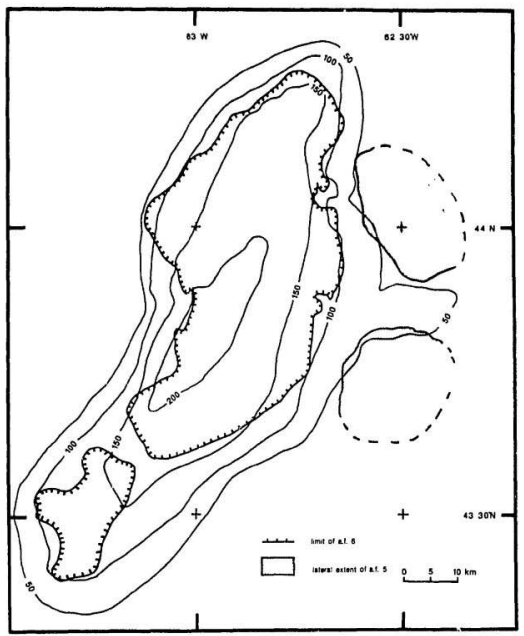

Figure 3.6. Paleobathymetric map showing the lateral extent of acoustic facies 5 and 6 . Acoustic facies 5 is restricted to the central axis of the basin, while acoustic racios 6 is observed on the eastern flank. Contours are in ms twt below a datum plane at $110 \mathrm{~m}$ below present day sea level. The datum plane was chosen to reflect possible lowered sea level. 
Acoustic facies 6 (a.f. 6) is generally transparent on both Huntec and NSRFC records, with one continuous coherent reflection visible in the middle, snd some weak continuous coherent reflections near the base. The top of a.f. 6 is characterised by a weak reflection, exhibiting reflectivity values of sbout $5 \%$, and is marred by small features, termed 'pockmarks' by King and MacLean (1970). Sidescan sonar records show pockmarks to be roughly circular and of variable size (Josenhans et al., 1978; Hovland et al., 1984). The base of a.f. 6 is marked by small erosional features, which have been interpreted as relict pockmarks, formed at a surface, and subsequently buried (Josenhans et al., 1978; Hovland et al., 1984). This acoustic facies is restricted to the central part of Emerald Basin (figure 3.8), and is equivalent to the LaHave Clay facies of King and Fader (1986).

Acoustic facies 7 (a.f. 7 ) appears to be a single or a series of convex upward reflections, below which there is a package of incoherent reflections (figure 3.2). Occasionally, coherent reflections are visible within a.f. 7 , which can be correlated to coherent reflections beyond the limit of occurrence of the facies. As underlying reflection events are apparently attenuated by a.f. 7 , other authors have described such facies as acoustic wipeout zones (Belknap et al., in press), acoustic mask (Hutchins et al., 1976; Josenhans et al., 1078), acoustically turbid zones (Schubel and Schiemar, 1973), shadow zones (Harbison, 1969; Van Weering et al., 1973), impenetrable layers (Keen and Piper, 1976), acoustic blanking (Boulton et al., 1981), acoustic impenetrability (Belknap tㅡ al., 1086), and masking reflections (Acesta, 108.1). Acoustic f cies 7 grades laterally into a.f. 4 and 6. Acoustic facies 7 is restricted to the central axis of the basin (figure 3.7). Acoustic facies 7 has been attributed to diffused gas in the sediment (Josenhana ot al., 1978; King and Fadrr, 1986). 


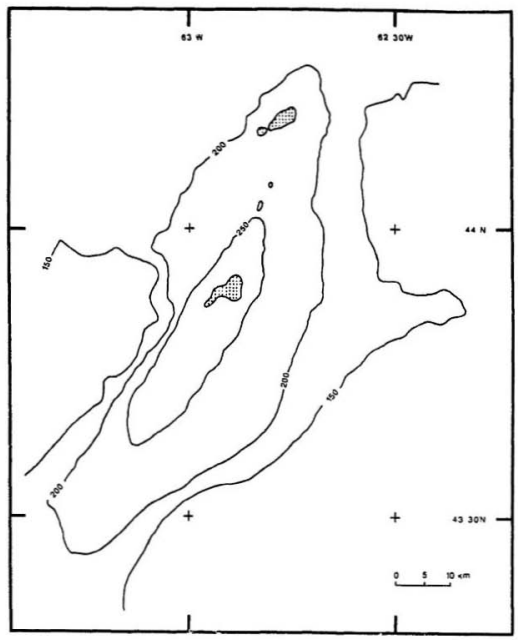

Figure 3.7. Distribution map of acoustic facies 7 plotted against present day bathymetry. Contuurs are in metres. Acoustic facies 7 is restricted to the central axis of Emeralt] Basin. 


\subsection{Depositional Sequences}

Six depositional sequences, numbered from 0 to 5 , are identified in the stratified sediments of Emerald Basin.

The lower boundary of depositional sequence 0 (d.s. 0 ) is the erosional upper surface of acoustic facies 3. The upper boundary of d.s. 0 is marked by apparent onlap at the flanks of small moraines (figure 3.8). Depositional sequence $\mathbf{0}$ typically consists of acoustic facies 4 reflections. Internal coherent reflections are abruptly interrupted by "lift-off" moraines (King and Fader, 1986) (figure 3.3). Detailed examination of the internal reflections in d.s. 0 reveals that small scale undulations in the uppermost reflections are often recorded in the underlying reflections, as occurs when multiples are present (figure 3.9). The detail to which the band of lower reflections mimies the upper boundary of d.s. 0 is unmatched by any similar bands of reflections in Emerald Basin. Such a series of reflection events could be caused by a well-draped sequence of stratified sediments, by interformational multiples, or by reverberations generated by deep reflections of a ringing source (Simpkin, pers. comm., 1987). The intensity of the upper boundary of d.s. 0 implies a large acoustic impedance contrast. None of the other reflections near the same stratigraphic level display a similar acoustic impedance contrast. As two reflectors with large impedance ent:asts are required to generate interformational multiples, d.s. 0 cannot be a series of interformational multiples. Figure 3.10 illustrates that the internal reflections in d.s. 0 are correlatable between two crossing seismic lines, one collecied by the Huntre DTS, and the other by the NSRFC V-fin sparker. Any reverberation generated by a particular system would not be expected to correlate to reverheration generated by the other system. The degree of correlation observed 
$\circ$ 으
ㅊ

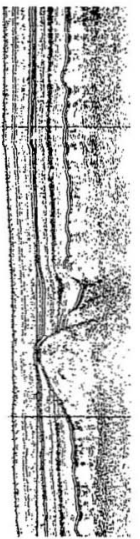

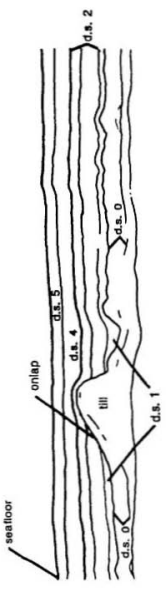

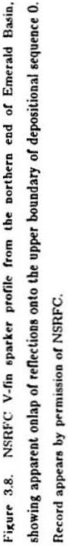




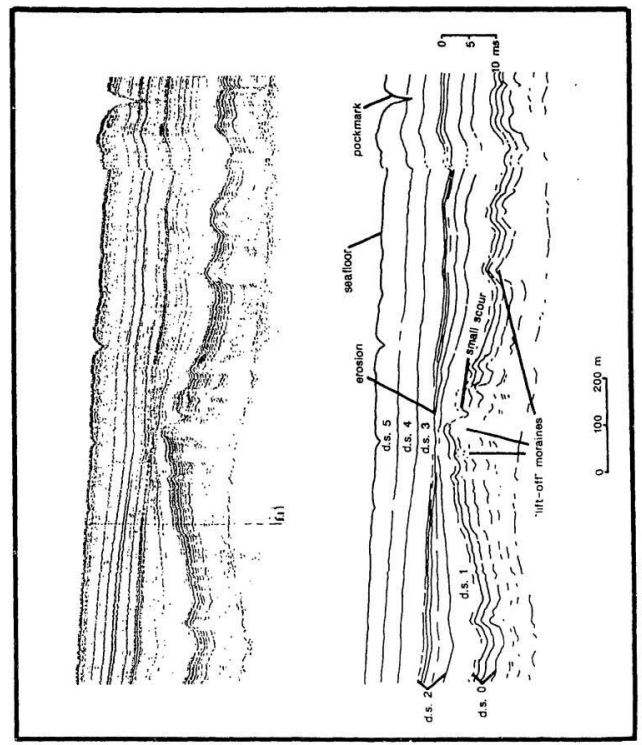

Figure 39 NSRFC V-fin sparker profile from the eastern flank of finerald flaven Renertions within depositional sequesce 0 are rreulat, exerpt near the small srour-lile

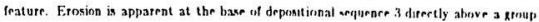
of "lift-off" moraines Record appears by permesuen of NStetc. 


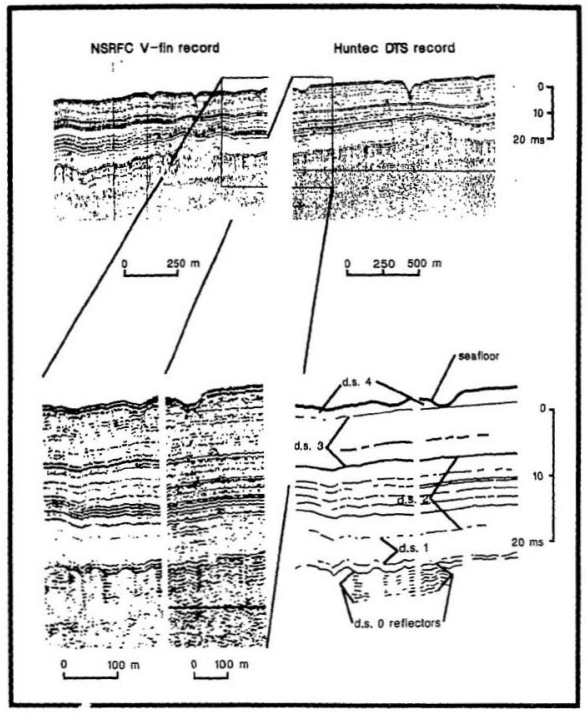

Figure 3.10. Crossover of Huntec DTS and NSRFC V-fin sparker profiles on the eastern nank. Note the high degree of correlability of depositional sequence boundaries and internal reflection events, especially within depositional sequence 0 . 
in figure 3.10 precludes reverberation as the sole cause of the reflections in d.s. 0 . The morpholegy of the upper boundary of d.s. 0 is not carried through the underlying reflections of d.s. 0 near a scour-like feature (figure 3.9 ), which provides evidence that the reflections are real. The internal reflections of d.s. 0 probably represent real reflection events in some parts of Emerald Basin, and reverberation elsewhere.

Depositional sequence 1 (d.s. 1) is uniformly draped over d.s. $\mathbf{0}$, except over some topographic highs (figure 3.8). Its lower boundary is defined as the upper buundary of d.s. 0 . Reflections of overlying sequences onlap ontu the upper reflection of d.s. 1, implying a non-d positional hiatus near topographic highs (figure 3.11). The upper boundary if d.s. 1 is the lowermost reflection in a prominent band of reflections correlatable across the basin. Depositionnl sequence 1 is characterised by a.f. 4 within the basin, and by a.f. 5 on the basin flanks.

The lower boundary of depositional sequence 2 (d.s. 2) is the upper boundary of d.s. 1, while the upper boundary is defined by apparent onlap and non-deposition at the basin Manks and by apparent erosional truncation or toplap of the underlying reflections (figure 3.0). The upper boundary of d.s. 2 ean be eorrelated to the boundary between Emerald Silt facies A and B of King and Fader (1988), which was described as being an unconformity of wide regional extrnt. Depositional secquence 2 is characterised by a.f. 4 within the basin, and by a.f. 5 on the basin fanks. The internal reflections of d.s. 2. while observed to be deaped over thr underlying reflections, show great asymmetry about topographical highs, particularly on the eastern Mank of Emerald Basin (figure 3 12). This marked asymmetry is uniqun (o) d.s. 2 . 


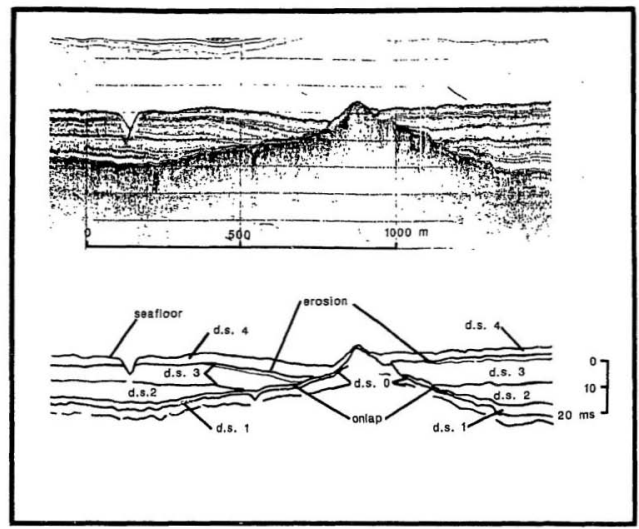

Figure 3.11. Interpreted NSRFC V-fin profile over a small moraine on the eastern nank of Emerald Basin, showing apparent onlap on the upper boundary of depositional sequence 1, and erosion at the base of depositional sequence 4. Record appears by permission of NSRFC. 


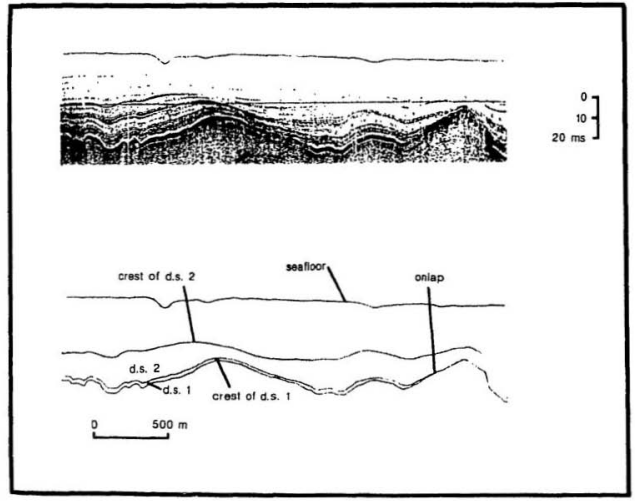

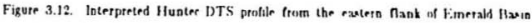
showing that depositinnal serguener 2 is preferentially areumulated on the left side of the topegraphic high left of the centre of the figure leffertuona apparently onlape into the upper beundary of depositional serquener 0 at right 
The upper boundary of depositional sequence 3 (d.s. 3 ) is defined as an erosional unconformity (figures $3.11,3.13$ ). Erosion at this reflection is apparent around topograph: highs in Emerald Basin, as well as on all of the basin flanks except to the southeast, where the two bounding reflections define a sequence which steadily increases in thickness to the south (figure 3.14). Depositional sequence 3 is characterised by a.f. 4 and, in places, a.f. 7.

Depositional sequence 4 (d.s. 4) overlies d.s. 3 in the centre of the basin and d.s. 2 on the northern and southwestern flank of the basin. Its lower boundary is the widespread erosional event at the upper boundary of d.s. 3, while its upper boundary is defined by apparent onlap on the northern flank (figure 3.15). Depositional sequence 4 is characterised by a.f. 4 and 7 .

Depositional sequence 5 (d.s. 5 ) is the uppermost depositional sequence in Emerald Basin. Its lower boundary is defined as the upper boundary of d.s. 4, whereas its upper boundary is defined as the seafloor. It is characterised by a.f. 6 and a.f. 7 .

\subsection{Implications of thickness variability}

The depositional style of a seismic depositional sequence can be used to suggest its origin. Barrie and Piper (1982) demonstrated three depositional styles observed in acoustic profiles in Makkovik Bay on the coast of Labrador: ponded, conformable cover, and onlapping basin-fill (figure 3.16). A fourth depositional style, wedging, indicates the dominance of currents during deposition (Piper et al., 1983). The conditions in figure 3.16 represent endmembers, whereas there is probably a continuum where more than one process operates. By considering 

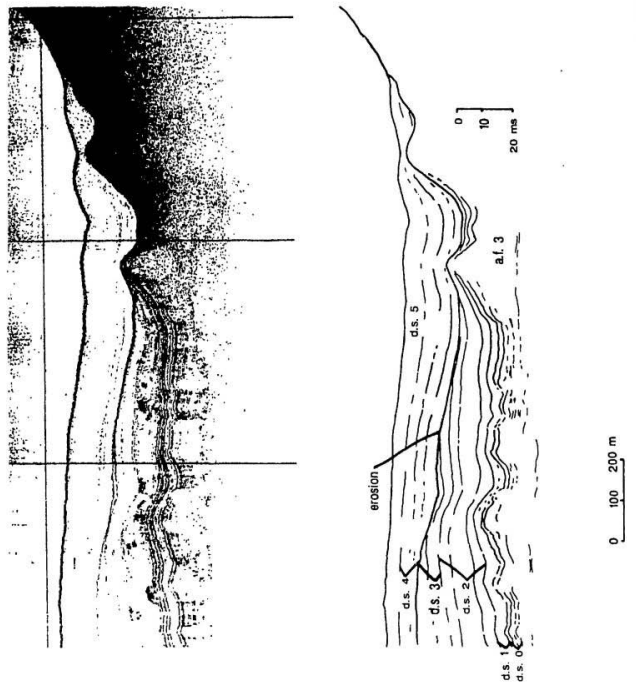

Figure 3.13. Interpreted NSRFC V-fin profile froin the weste'n Nank of Einrrald Basin. showing the erosional truncation of deponitional seyurace 3 internal reflections at the hase of depositional sequence 1 . Record appears by perminsion of NSRFC: 


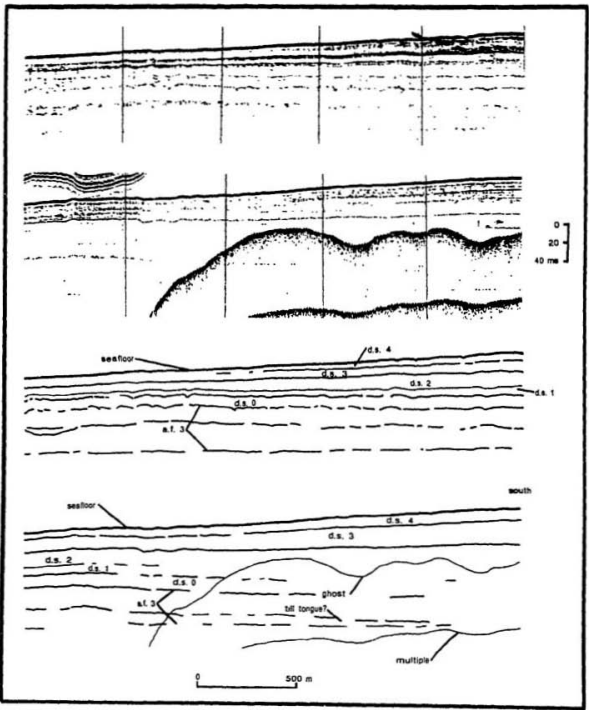

Figure 3.14. Interpreted NSRFC V-fin profile from the eastern flank of Emerald Basin, showing the progressive southward thickening of all depositional sequences. Record appears by permission of NSRFC. 

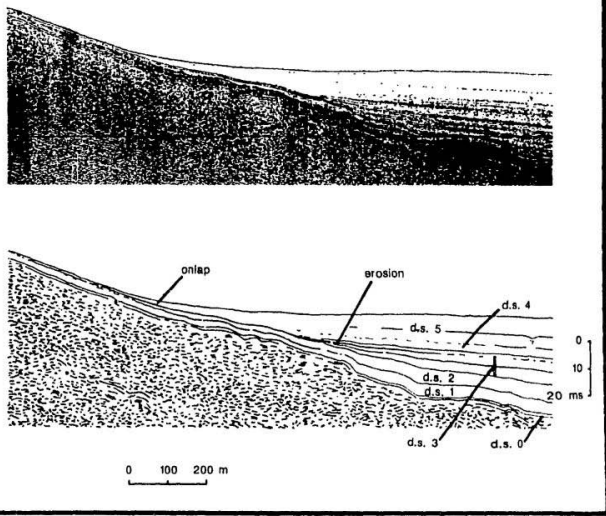

Figure 3.15. Interpreted Huntec DTS profile from the northern nank of Einerald Basin. showing erosion at the base of depositional sequence 4 and oslap of drpomitional seyuence 5 onto depositional sequence 4. 
Figure 3.16. Cartoon depicting the effects of dominant depositional m-chanism on acoustic style of a depositional sequence. Modified from Piper et al. (1983) and Syvitski (in press). 

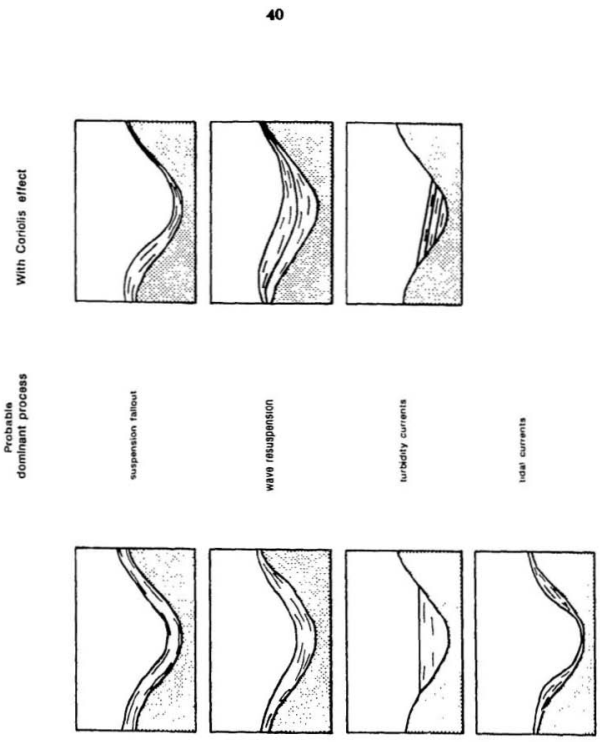

产

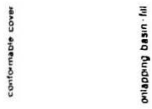

$\frac{8}{8}$

9
8
8 
depositional style as a continuum, rather than as an absolut.e, the relative importance of two or more mechanisms can be assessed.

Thicknegs variability is considered to be a function of depositional and erosional style, sediment source location, where thickness will increase with proximity to the source, and morphology of the underlying surface, where thickness will increase in troughs and decrease over crests. If a sequence has a conformable cover depositional style, the isopach map of this sequence will reflect both large scale and small scale variations in the underlying morphology. The onlapping basinfill depositional style will result in an isopach map which preferentially represents large variations over small ones, although the small variations may be resolved if the sequence is thin. If the sequence is ponded, then large-scale variations will be recorded in the isopachs, but not small-scale variations, because the regional change in thickness of the sequence will be orders of magnitude greater than the change in thickness over small features. If the sequence demonstrates wedging, then the maximum thickness of the sequence does not occur in troughs, but rather on the flank of a topographical high.

\section{Depositional Sequence 0}

The thickest occurrences of d.s. 0 in Emerald Basin are found along the northern flank and the eastern flank south of the eastern channel, and in the eastern channel (figure 3.17). Within the basin, d.s. 0 is of uniform thickness, but thins rapidly towards the flanks. This sequence exhibits the conformable cover depositional style of Barrie and Piper (1882), which suggests deposition from suspension, including sediment plumes and ice rafting. The increased thickness of d.s. 0 on the eastern flank and in the northern end may be attributed to either 


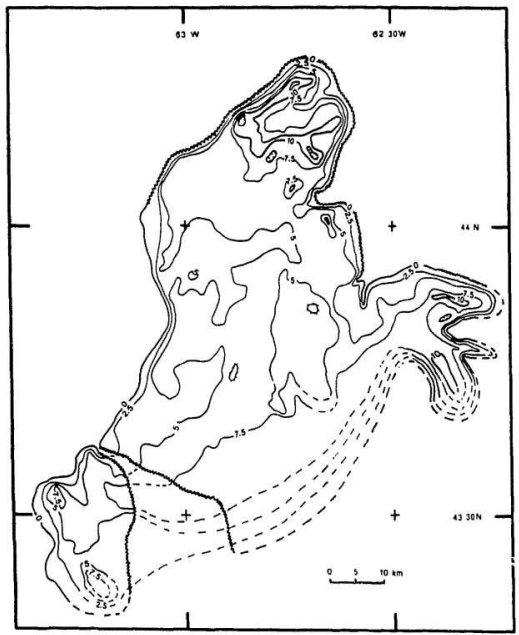

Figure 3.17. Isnpach map of depositional sequence 0. Contrurs in ths twe. The thickerss of depositional sequence 0 is considered where it consists of acoustic facies 4, 5, 6, of 7 . The serrations on the 0 ms contour represent intercalation with acoustic facies 3 . Dashrd lines represent inferred contours where no data is available. 
wedging by currents, or proximity to sediment source. If current wedging were solely responsible for the increased thickness of d.s. 0 on the flanks, then d.s. 0 should thicken on all of the nanks. As the nank thickening is restricted to the north and to the southeast, both of these areas were probably close to sediment sources.

\section{Depositional sequence 1}

Depositional sequence 1 is deposited as a relatively uniform blanket throughout Emerald B sin, thickening slightly alcag the central axis and in the eastern channel, with the thickest deposit on the eastern flank south of the eastern channel (figure 3.18). Depositional sequence 1 exhibits a conformable cover depositional style, but further displays slight thickening in small troughs. This thickening is similar to the onlapping basin-fill style described by Barrie and Piper (1982), probably indicating a contribution by either storm wave resuspension or minor underflows. Overlying reflections terminate along the upper boundary of d.s. 0 only in the proximity of topographic highs, suggesting local non-deposition or erosion. The thickening along the northern and eastern flanks probably indicates the proximity of a sediment source.

\section{Depositional sequence 2}

Depositional sequence 2 blankets Emerald Basin, with thick patches in the eastern channel, along the central axis, and on the southeastern flank, and thinning

near the eastern flank north of the eastern channel (figure 3.18). Depositional sequence 2 asymm trically overlies topogiaphic highs, especially near the eastern channel (figure 3.13). which is similar to the onlapping basin-fill style of deposition, modified by the Coriolis effect (figure 3.16). The thickening of d.s. 2 along the 


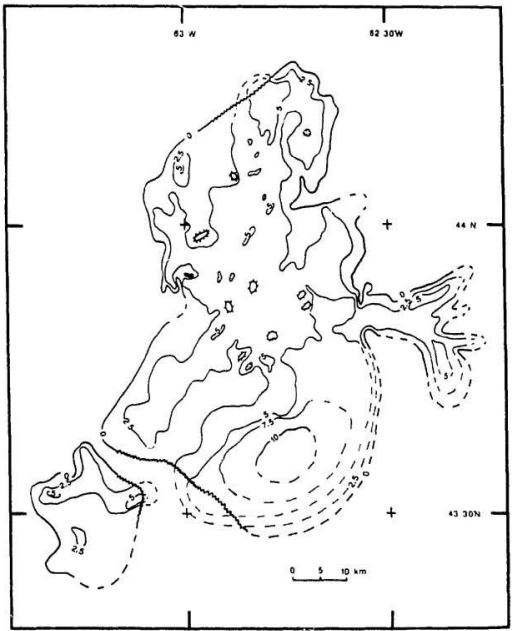

Figure 3.18. Eraparh map of depositional sequence 1. ('tonteurs in uns twt. Thr thirkmss of deprositional sequence 1 is considered whese it eonsists of aroustic faries 4. 5, 6, or 7 . The serfaterns on the 0 mis rontout fepresent intercalation with acoustic facies 3. Dashed lanes represent inferefed contours where no distia is avaliable. 


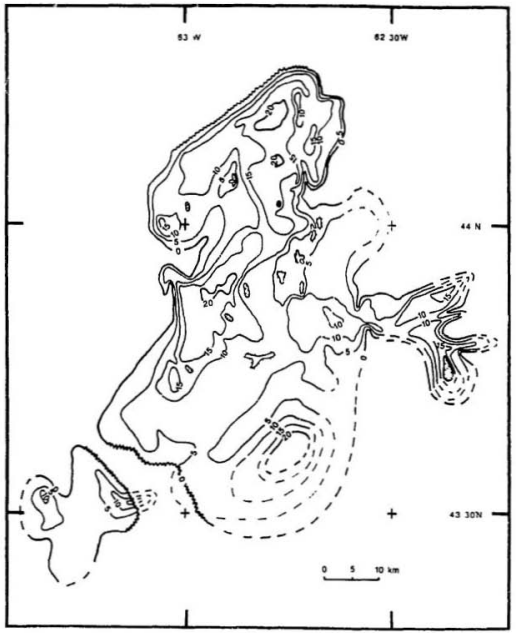

Figure 3.10. Isopach map of depositional sequence 2. Contours in ms twt. The thickness of depositional sequence 2 is considered where it consists of acoustic facies $4,5,6$, or 7 . The serrations on the $0 \mathrm{~ms}$ contour represent intercalation with acoustic facies 3 . Dashed lines represent inferred contours where no data is available. 
central axis of the basin also suggests that d.s. 2 exhibits the onlapping basin-fill style of deposition. The increased thickness observed along the southeastern flank, is not suggestive of onlapping basin-fill, and probably represents proximity to a sediment source.

\section{Depositional sequence 3}

The thickest deposits of d.s. 3 are observed at the northern end, along the central axis, along the southeastern flank of the basin, and in the enstern channel, while the thinnest deposits are found along the eastern flank and near the western flank in the northern end of the basin (figure 3.20). The thickening of d.s. 3 on the southeastern flank probably indicates sediment supply from the south into the basin. The thickening of d.s. 3 along the central axis anc in the eastern channel suggests that d.s. 3 exhibits the onlapping basin-fill style of deposition, implying that the sediment is either reworked by storm or tidal currents, or that sediment rained out of suspension, possibly with a minor contribution by turbidity currents. An alternate explanation is that the thickening in the centre of the basin is apparent because d.s. 3 was eroded from the hasin flanks during a widespread erosion event at the base of d.s. 4 (figure 3.21). The boundary of this erosive event is roughly parallel to paleobathymetric contours in the northern end of the basin, but in the central basin, it increases in depth, probably in response to stronger, deeper currents in the middle of the basin. Storm currents would be accelerated near the steep flank of Sambro Bank, and near the eastern channel. The absence of depositional asymmetry around topographic highs implies little reworking by currents while d.s. 3 was being deposited. 


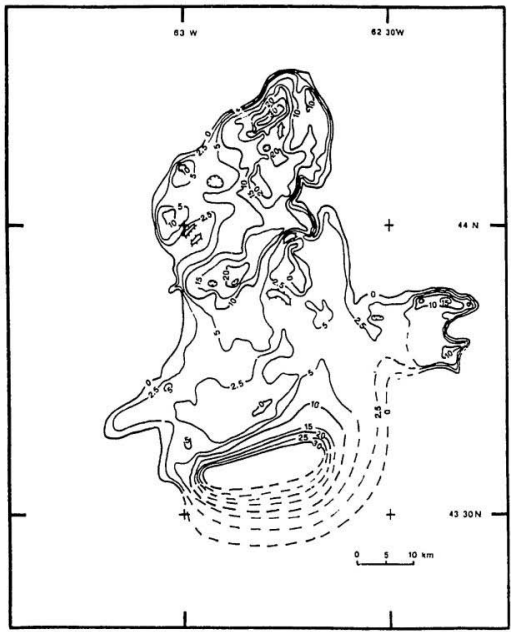

Figure 3.2n. Isopach map of depositional sequence 3. Contours in ms twt. Thickness of depositional sequence 3 is considered where it consists of acuustic facies $4,5,6$, or 7 . Dashed lines represent inferred contours where no data is available. 


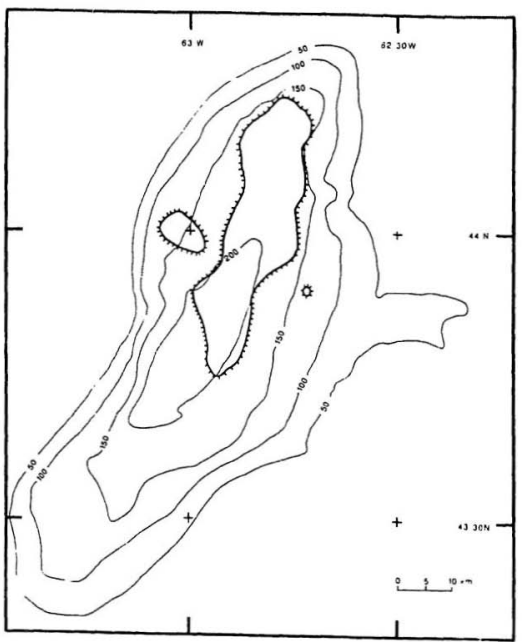

Figute 321 . The extent of erosion at the lase of drponitienal sefuener $f$ on a

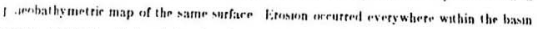
everpt within the limits of the elowed eurses, Contonrs ate in ma tut belou a datum plane at $110 \mathrm{~m} \mathrm{~h}$-1. 


\section{Depositional sequence 4}

Depositional sequence $\mathbf{4}$ is thickest in the southern end of Emerald Basin, particularly along the southeastern flank, and is thinnest near the eastern nank, and near the western flank in the northern half of the basin (figure 3.22). Depositional sequence 4 exhibits the conformable cover depositional style, implying that sedimentation is dominated by raining out processes. The thickening of d.s. 4 in the southern end of the basin is probably related to the proximity of a sediment source south of Emerald Basin.

\section{Depositional sequence 5}

Depositional sequence 5 is thickest in the northern end and along the central axis of Emerald Jasin, but is absent in the eastern channel, and shows no thickening along the eastern flank (figure 3.23). Depositinnal sequence 5 appears to exhibit the onlapping basin-fill depositional style, implying a dominance of either storm wave reworking, or sediment raining out of suspension with a minor contribution from turbidity currents. The wicespread erosive event at the present-day seafloor (figure 3.24) thins d.s. 5 around the basin flanks. The boundaries of this erosive event are approximately parallel to bathymetric cont $n u r s$, but increase in depth near the steep slope of the western flank, and near the mouth of the eastern channel, where currents might be expected to be accelerated. Reworking of sediment in the southern end of Emerald Basin is as a result of storm-driven currents (Kontopoulis and Piper 1982), and it is probably these currents that are presently reworking the seafloor in Emerald Basin. 


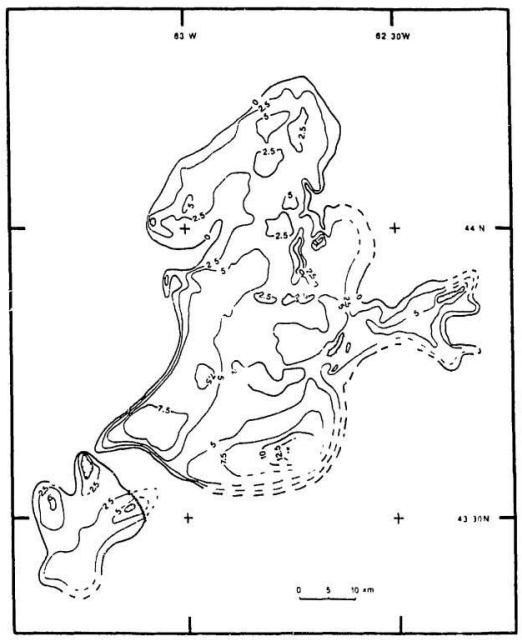

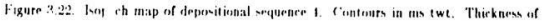

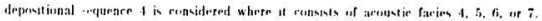

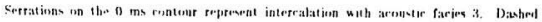
lines represent inferred contours where ne d.ta is av:ulable. 


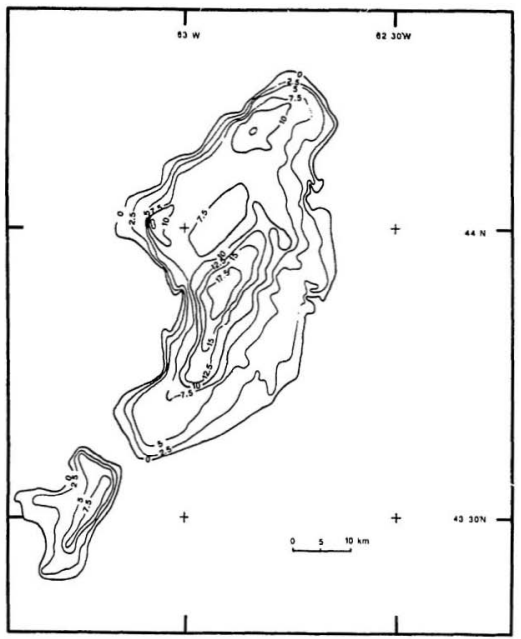

Figure 3.23. Isopach map of depositional sequence 5. Contours in ms twt. 


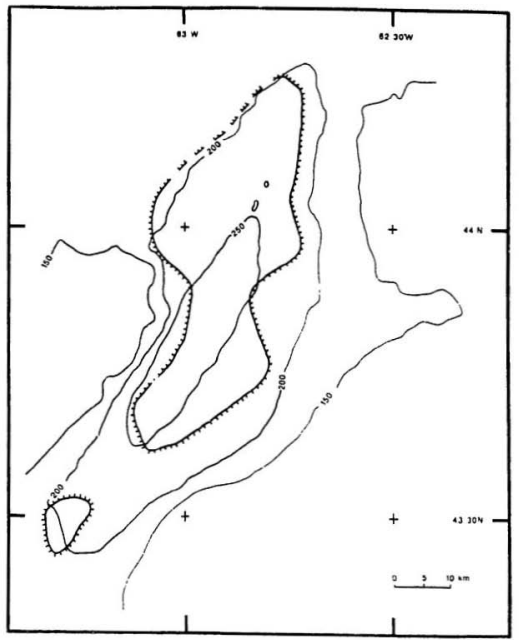

Figure 3.24. Map showing the extent of eroswa at the peresent-tiay seafluet, as determined from acoustir profiles. Frosinn oerufs exerywhere within the basin exerpt within the limits of the closed rurves. Contours are in $m$ b. 1 . 


\section{Sedimentology}

\subsection{Lithofacies definition}

On the basis of descriptions of split core faces, x-radiographs, grain-size data, and sand and gravel mineralogy, five lithofacies are identified.

Lithofacies 1 consists of olive-grey (2.5Y4/1-5Y4/2) or olive-brown (10YR3/1) sandy silt with occasional wispy laminations observed in x-radiographs. The sand content is $15-30 \%$ (figure $4.1 \mathrm{a}$ ), of which the $>500 \mu \mathrm{m}$ fraction is $80-98 \%$ biogenic (figure 4.1d), being primarily foraminifera. Some slight bioturbation and pyrite mottling are present. Macrofauna consists of bivalve mollusc shells and scaphopods.

Lithofacies 2 consists of olive-grey $(5 \mathrm{Y} 4 / 2-2.5 \mathrm{Y} 3 / 2)$ sandy silts with occasional sandy lamina and rare sand layers. The sand content is as high as $32 \%$ and only rarely falls below $20 \%$ (figure $4.1 \mathrm{~b}$ ). The sand consists primarily of quartz grains and metamorphic rock fragments with less than $1 \%$ biogenic materials (figures $4.1 c$, d). X-radiographs show well defined laminations, espreially near the sand layer in core 87-003-006. Strustures within the sand layer are similar to ripples (figure 4.2a). Macrofauna consists of bivalve molluscs, but scaphopods are absent.

Lithofacies 3 consists of olive grey-brown (2.5Y3/2-5Y4/1-5Y4/2) silty muds with occasional sandy laminations. Sand content is generally below $10 \%$, but reaches $20 \%$ in samples of coarse laminae, while clay content is generally $25-50 \%$, but is as low as $10 \%$ in a few samples (figures $4.1 \mathrm{a}, \mathrm{b}$ ). The coarse sand of this facies is dominated by quartz grains (figure 4.1c). The fossil content of the coarse sand $f: a c t i o n$ is much lower than that of lithofacies 1. while authigenic mineral 
Figare 4.1. Ternary plots depicting the characteristics of litholacies 1-5.

a) Grain-size distributions from sieve-hydrometer data. Classification scheme is that of Folk (1954).

b) Grain-size-distributions from Coulter counter data. Classification scheme is that of Folk (1954). Lithofacies appear more silty than they do in 4.1 a because the Coulter counter assumes there is no material finer than the finest resolvable size.

c) Relative amousts of quartz (including quartzite), feldspar, and rock fragments from the $>500 \mu \mathrm{m}$ iraction.

d) Relative amounts of organic materials (including Coraminifera, fish bones and scales, and shell fragments), authigenic minerals (generally pyrite and goethite), and inorganic materials (rock and non-authigenic mineral fragments) from the $>500 \mu \mathrm{m}$ fraction. 

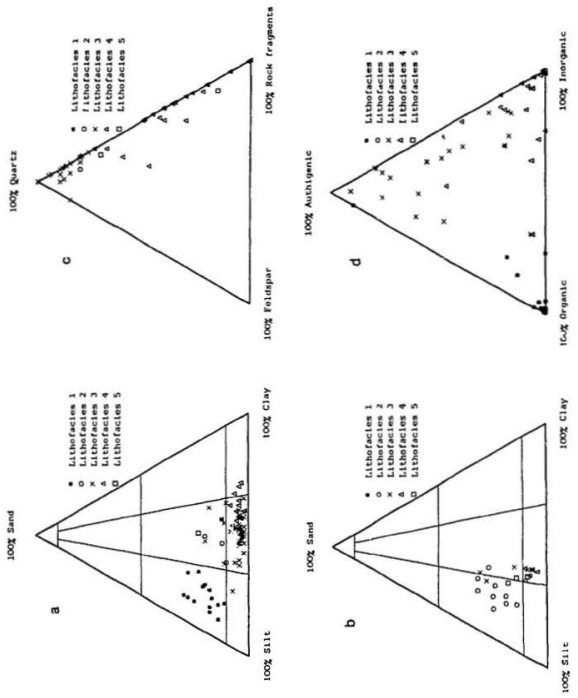
Figure 4.2. Core X-radiographs of sedimentary structures.

a) Possible ripple within a sandy horizon in lithofacies 2, core $006,797 \mathrm{~cm}$.

b) Pyritized burrow fillings in lithofacies 3 , core $004,391 \mathrm{~cm}$.

c) Laminations in lithofacies 5 , core $004,1691 \mathrm{~cm}$.

d) Laminations in lithofacies 2 , core $006,750 \mathrm{~cm}$.

e) Gravel and sand in lithofacies 4, core $021,194 \mathrm{~cm}$. 
a
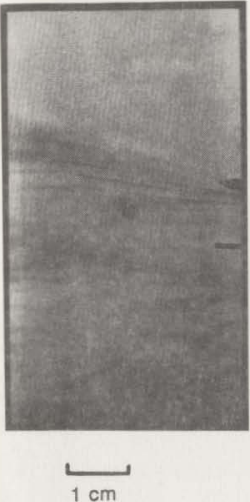

C
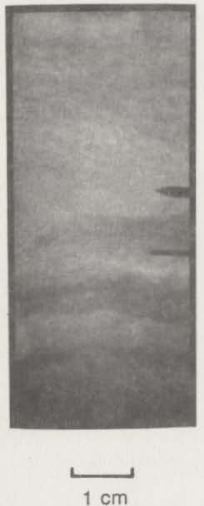

d

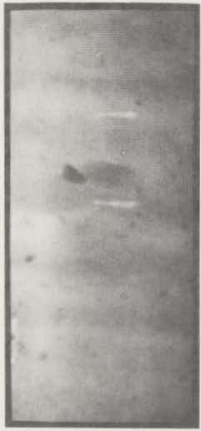

$\stackrel{\mathrm{cm}}{\longrightarrow}$ b
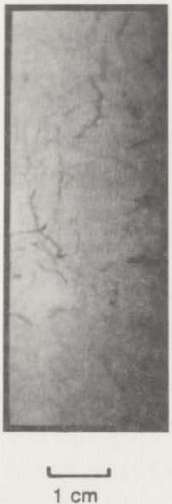

$\theta$
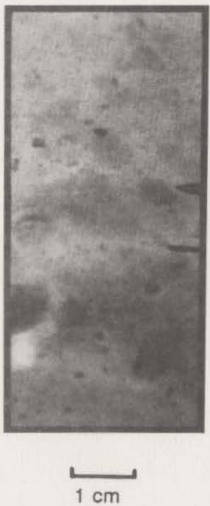
content is much higher (figure 4.1d). The dominant authigenic mineral present is pyrite, both recovered in samples and visible in $\mathrm{x}$-radiographs (figure $4.2 \mathrm{~b}$ ), which has crystallized in burrows. The facies is slightly bioturbated. Macrofauna are primarily bivalve molluses and gastropods, with very few scaphopods near the top of the facies.

Lithofacies 4 consists of olive grey-brown (2.5Y3/2-5Y4/1-5Y4/2) muds with occasional black (N3/0) bands up to $15 \mathrm{~cm}$ thick and brown (10YR3/2) ungraded sandy and gravelly bands up to $10 \mathrm{~cm}$ thick. Scattered gravel and dropstones $\sim 5$ $\mathrm{mm}$ in diameter, and up to $10 \mathrm{~cm}$ in length are present, and increase in abundance downcore. This facies contains less than $10 \%$ sand, and $50-70 \%$ clay (figure 4.1a). The coarse sand fraction is $5-40 \%$ biogenic, with the lowest percentages of biogenic materials near the base of the facies (figure 4.1d). The coarse sand is dominated by metamorphic rock fragments (figure 4.1c). Goethite dominates the authigenic minerals, although pyrite is present in samples near the top of the facies. The facies is heavily bioturbated, usually with burrows which ara darker than the surrounding sediment. Macrofauna consists of gastropods and bivalve molluses.

Lithofacies 5 consists of stiff brownish grey (2.5Y3/2-5Y3/2) gravelly sandy muds (figures $4.1 \mathrm{a}, \mathrm{b}$ ) with ocrasional laminations (figure $4.2 \mathrm{c}$ ). The coarse sand is primarily rock fragments, with minor biogenic and authigenic components (figure 4.1c). The facies is generally unbioturbated and barren of shells.

Lithofacies correlations between piston cores across the basin is straightforward (figure 4.3). Erosion at the present day seafloor is apparent in the cores taken on the eastern flank 
Figure 4.3. Litholacies correlations between piston cores from Emerald Basin. Core locations given in figure 2.2 . 


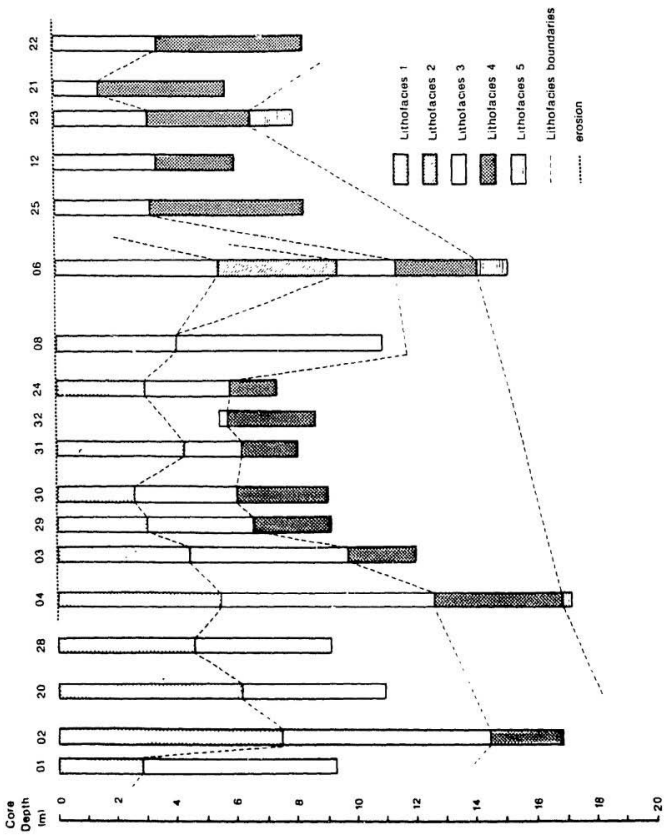




\subsection{Coarse sand and gravel petrology}

Pebbles, gravel, and coarse sand samples from all lithofacies have been studied. The coarse sand residues $(>500 \mu \mathrm{m})$ are taken from $25 \mathrm{~cm}^{3}$ foraminifera samples at $25 \mathrm{~cm}$ intervals down core 004 . Gravel is obtained from sieved grain size samples, and dropstones are recovered directly from cores.

The non-biogenic content of the sand fraction in lithofacies 1 is very low (figure 4.1d). Two samples contained enough material to plot on a quartz-feldsparrock fragment (QFR) ternary plot (Folk, 1980) (figure 4.1c). Other samples contained three or fewer grains of non-biogenic sand. Most of the quartz is in the form of clear composite metaquartzite grains. The rock fragments include schists, chert, and sandstone. One sample from lithofacies 2 is dominated by quartzite and quartz grains, with minor metamorphic rock fragments and $\mathrm{K}$ feldspar grains (figure 4.1c). The coarse sand fraction of facies 3 is $20-60 \%$ inorganic (figure $4.1 \mathrm{~d}$ ), and is dominated by single or composite clear quartz grains, with minor quantities of cloudy vein-quartz (figure $4.1 \mathrm{c}$ ). The dominant rock fragments in this facies are metamorphic rock fragments with minor $K$ feldspar. The non-biogenic coarse sand fraction in lithofacies $\mathbf{4}$ is dominated by rock fragments, primarily schists with minor amphibole and chert grains, and clear composite metaquartzite grains (figure 4.1c). One dropstone ( $7 \mathrm{~cm}$ in length), identified as a quartz-biotite schist, has been recovered from lithofacies 4. The gravel and coarse sand of two samples from lithofacies $\mathbf{5}$ are primarily metamorphic rock fragments and quartzite with minor $\mathrm{K}$ feldspar (figure 4.1c).

Very few igneous minerals are present in the coarse sand fraction. 
Metamorphic rock fragments dominate, implying that most of the sands and gravels are derived from erosion of the Meguma Group, which underlie cosstal Nova Scotia and the inner third of the continental shelf (King and Maclean, 1976).

\subsection{Grain-size analysis}

Twenty-two samples representing four lithofacies were analyzed on a Coulter Counter (Coulter Electronics, 1979). Seventy-five samples representing all five lithofacies were snalyzed using sieves and hydrometers by Maritime Testing (Moran, pers. comm., 1988). Grain-size curves are plotted against the scale, as suggested by Inman (1952). The sieve samples were chosen to determine the lithofacies characteristics, whereas Coulter Counter samples were used to investigate smallscale features and to provide grain-size distribution plots at $1 / 3 \Phi$ intervals.

The Coulter Counter results in this thesis have been modified to correct for an error introduced by the processing system at BIO. This error originated when the results of the $560 \mu \mathrm{m}$ tube were combined with the results of the $30 \mu \mathrm{m}$ and $200 \mu \mathrm{m}$ tubes. Addition of the coarse fraction resulted in a suppression of the fine fraction which varied with the amount of coarse material in each sample. The resulting plots showed a slight reduction of the $<\phi \phi$ fraction, and an extreme reduction of the 5 to $6 \phi$ fraction (figure 4.4). As the reduction was a function of the amount of coarse material in the sample, the errors varied from sample to sample. In order to correct for this error, the following procedure was carried out on each sample. The grain-size curve produced from all three of the tubes was compared with that of the two smaller tubes. The total grain-size curve was assumed to be correct for material $>4.5 \phi$, while the fine grain-size curve was assumed to be correct for 

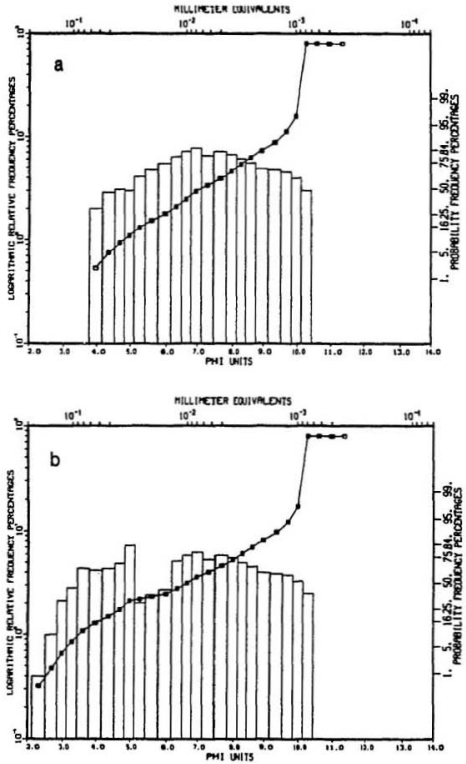

Figure 4.4. Raw Coulter counter data for one sample, illustrating the distortion introduced when adding the data obtained using a $560 \mu \mathrm{m}$ aperature to data obtained using $30 \mu \mathrm{m}$ and $200 \mu \mathrm{m}$ aperatures. (a) Analysis using the two small aperatures. (b) Analysis combining data using all three aperatures. 
material <4.5\%. All of the $<4.5 \$$ values on the fine grain-size curve were sdjusted by the same factor so that the two curves would fit together without any discontinuity. The two curves were then merged at $4.5 \$$ pusition on the size axis, and the hybrid curve was renormslized.

\section{Curve Dissection}

Cumulative grain-size da:a are usually plotted against a probability axis because normal distributions plot as straight lines (Rissik, 1941). Both Coulter Counter data, obtained in this study, and sieve-hydrometer data are plotted against a probability axis, using a FORTRAN routine developed by the suthor. The cumulative curves do not plot as straight lines, but ratber as "segmented" curves (figure 4.5). Previously, "segmented grain-size curves have been considered to be a mixture of two or more truncated non-overlapping log-normal populations (Visher, 1969), a mixture of two or more overlapping log-normal populations (Harding, 1948; Spencer, 1083), a log-hyperbolic curve (Bagnold and Barndorff-Nielsen, 1980; Christiansen et al., 1084), or the result of hydraulic processes (Bridge, 1981).

Visher (1968) supposed that a segmented cumulative grain-size curve could be represented by straight line segments, each of which would represent one mode of transport. The truncation of each of the segments was believed to result because grains of a certain size would be transported by one and only one mechanism. Shiki and Yamazaki (1985) reject this bypothesis, as samples from the Okinawa Trench curved continuously, and would thus require numerous very short segments. Christiansen et al. (1984) also demonstrate that this method is not applicable because grains transported by one mechanism displayed a log-hyperbolic size distribution rather than the supposed truncated log-normal distribution. 

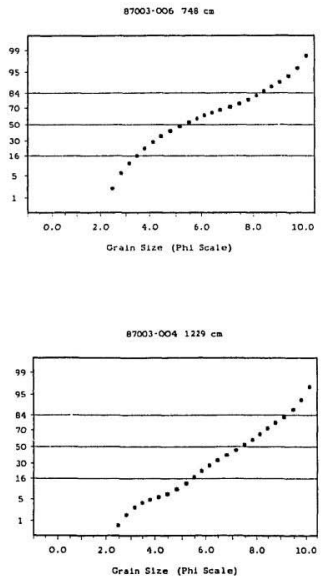

Figure 4.5. Cumulative grain-size curves for two samples analyzed on the Coulter counter. Note the "segmented" appearance of the curves. 
Previous workers have considered non log-normal cumulative grain-size curves to be the result of two or more grain populations (eg. Spencer, 1863; Shiki and Yamazaki, 1985). Variations in kurtosis, skewness, and standard deviation of a grain-size population have been tied to variations in the composition and relative amounts of the composite populations (Folk and Ward, 1957; Spencer, 1963). Graphical dissection techniques have been presented by Harding (1949) and Hald (1952). A typical cumulative grain-size distribution resulting from the mixing of two overlapping log-normal populations will consist of a concave-downward section and a concave-upward section (figure 4.6), and the cumulative probability $(\mathrm{P}(\mathrm{y}))$ for particles finer than diameter ' $y$ ' is

$$
P(y)=\frac{1}{\sqrt{2 \pi}} \int_{-\infty}^{y} P_{1} \cdot \exp \left(-\left(\frac{x-\mu_{1}}{\sigma_{1}}\right)^{2} / 2\right)+\left(1-P_{1}\right) \cdot \exp \left(-\left(\frac{x-\mu_{2}}{\sigma_{2}}\right)^{2} / 2\right) d x
$$

where $\mu_{1}, \mu_{2}$ are mean grain sizes of the two populations, $\sigma_{1}, \sigma_{2}$ are the standard deviations of the two populations ( $\phi$ scale). $P_{1}$ is the relative weight of the first parent population. If the two components do not overlap too much, then the composite curve will have one inflection point. The location of the inflection point was used by Harding (1949) to estimate the relative amounts of the two log-normal components. This estimation is reasonable if the two populations have similar standard deviations and are mixed in subequal amounts, but is misleading when well sorted and poorly sorted components are mixed in unequal amounts, especially if the mesn diameters of the two populations are similar. The situation is complicated when more than two components are present. For a mixture of " $n$ " log-normal components, $\mathrm{P}(\mathrm{y}))$ is found to be:

$$
P(y)=\frac{1}{\sqrt{2 \pi}} \sum_{k=1}^{n} P_{k} \int_{-\infty}^{y} \exp \left(-\left(\frac{x-\mu_{k}}{\sigma_{k}}\right)^{2} / 2\right) d x
$$




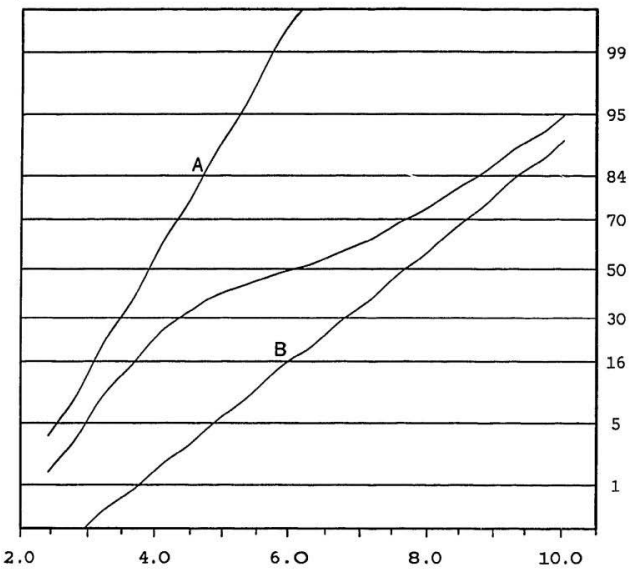

Grain Size (Phi Units)

Figure 4.6. The modelled cumulative grain-size curve (curved line) resulting from the mixing of two overlapping log-normal populations ( $A$ and $B$ ). The modelled curve is $40 \%$ population $A$ and $60 \%$ population $B$. 
Two parameters, the mean and the standard deviation, are required to define a log-normal population, but four parameters are required to define a log-hyperbolic curve. The log-hyperbolic distribution was first noted by Bagnold (1937). It derives its name from the shape of the log log plot of the relative weight of the grain size curve. Bagnold and Barndorff-Nielsen (1980) suggest a general mechanism by which a sediment with a log-normal distribution evolves into one with a $\log$-hyperbolic distribution during transport (figure 4.7). The expression for a log-hyperbolic cumulative curve is given below:

$$
\boldsymbol{H}(y)=\frac{\sqrt{\Phi_{\gamma}}}{\delta(\phi+\gamma) K_{1}\left(\delta \sqrt{\Phi_{\gamma}}\right)} \int_{\infty}^{y} e x p\left[-\frac{\phi+\gamma}{2} \sqrt{\delta^{2}+(x-\mu)^{2}}+\frac{\phi-\gamma}{2}(x-\mu)\right] d x
$$

where $\mathrm{H}(\mathrm{y})$ is the probability that a unit of sediment will be coarser than size $\mathrm{y}$, which is the natural logarithm of millimetre grain size, $\mu$ is the abscissa of the intersection point of the two asymptotic lines of the hyperbola, $\$$ and $\gamma$ are the slopes of the two asymptotic lines defining the hyperbola, and $\delta$ is a sealing parameter (figure 4.7). The function $\boldsymbol{K}_{1}(\cdot)$ is a first order modified Bessel function of the third kind (Bagnold and Barndorff-Nielsen, 1980). The resulting curve, when plotted against a probability axis, consists of a concave upwards section and a concave downwards section with one inflection point (figure 4.8). This curvature scheme is opposite to that of the composite curve in figure 4.6 and the data in figure 4.5. It is possible for two completely overlapping log-normal populations to produce a curve similar to a log-hyperbolic curve (figure 4.8), but the similarities are superficial. The composite curve has three inflection points, is symmetrical about the second inflection point, asymptotically approaching the population with the 
Figure 4.7. Explanation of the parameters of the Iog-byperbolit function. On a log-tog plot of the grain-size plot, the grain-size curve bas the form of an byperbola (curved line), defined by asymptotes of slope $\Phi$ and $\gamma$ (straight lines). $\delta$ and $\pi$ are sealing parameters. $\mu$ is the ordinate of the intersection point of the two asymptotes, while $\nu$ is the mode of the grain-size distribution. Sorting into a log-hyperbolic function occurs because the probability of a grain being present is a function of size. There is a probability that a grain is too large to bave been transported to a site, (line with slope $\Phi$ ), and a probability that a grain is too small to have been deposited at a site (line with slope $\gamma$ ). The grainsize distribution is therefore controlted by the two asymptotes. Modified from Bagnold and Barndorff-Nielsen (1980). 


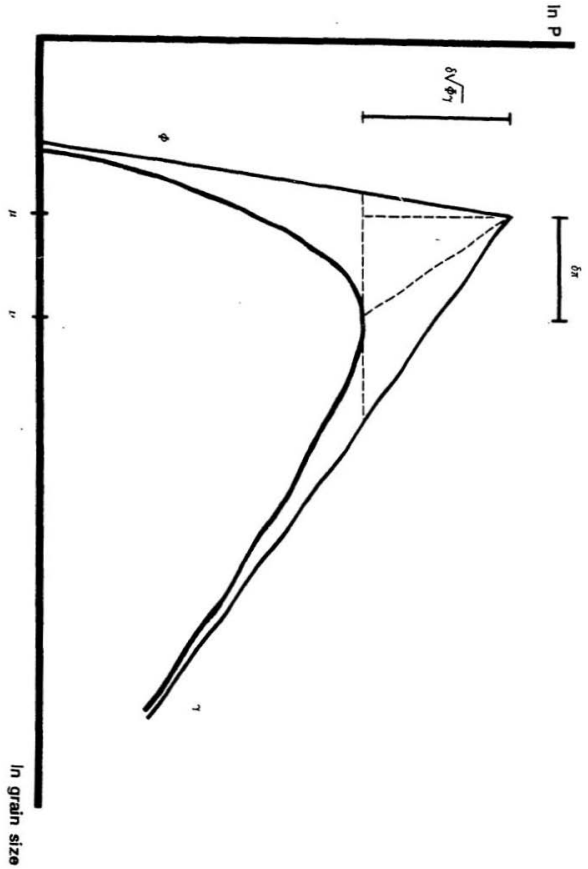




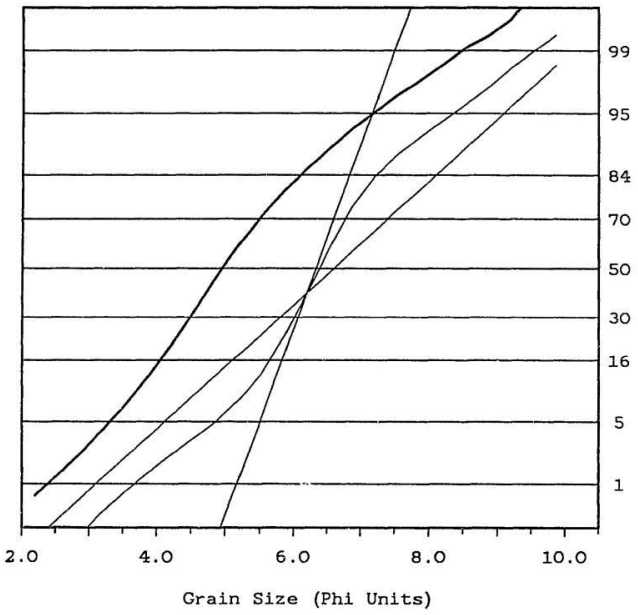

Figure 4.8. Comparison of log-hyperbolic cumulative grain-size eurve (bold curve) with a cumulative grain-size curve modelled from the mixing of two overlapping log-normal populations. Distortion in the log-hyperbolic curve above the $99^{\text {th }}$ percentile is due to inaccuracy of Bessel function table in Goudet (1965). 
larger standard deviation, while intersecting tangentially the population with the smaller standard deviation at the point of intersection of the two log-normal curves (figure 4.8). It is theoretically possible to distinguish a log-hyperbolic grain-size distribution from a $\log$-normal composite curve like that in figure 4.8 if accurate data from the tails of the distribution is available.

The grain size curves in this study are considered to be the sum of log-normal populations because the curvature scheme of the data is similar to that of two overlapping log-normal populations, but not that of a log-hyperbolic population (figure 4.5), and because previous models of marine sedimentation near ice margins predict at least two modes of deposition (eg. Drewry and Cooper, 1081; Powell, 1984). The majority of the curves studied require three component populations to produce a good fit. Coulter counter and sieve-bydrometer samples from core 006 are composed of two poorly sorted populations and one well sorted population. The Coulter counter samples from core 004 are generally composed of two well sorted populations and one poorly sorted population, whereas the sieve-hydrometer samples from core 004 are represented by one well sorted and two poorly sorted populations (figure 4.8). Sieve-hydrometer samples from core 002 represent lithofacies 1 and require as many as five components to produce a good fit.

All samples from cores 002,004 and 006 show a fine, poorly sorted component. In samples from core 002 , this component bas a mean of about $6.5 \$$ and a staptard deviation of $1.0-1.5 \$$. In samples from core 004 , this component typically has a mean of about $7.5 \Phi$ and a standard deviation of about $1.7 \Phi$. The fine component of core 008 samples is both finer and better sorted than that of core 004 samples, with 
Figure 4.9. Dissected cumulative grain-size curves, showing component log-normal populations (straight lines), modelled cumulative curves resulting from mixing the lognormal populations (curved lines), and the actual data (asterisks). Modelled curves in this and other figures are defined as form of $\Sigma \mathrm{P} \times(\mu \pm \sigma)$ where $\mathrm{P}$ is the relative weight of the population $(\mathrm{t}>\mathrm{P}>0), \mu$ is the mean of the log-normal component, and $\sigma$ is the standard deviation).

a) $0.20 \times(3.98 \Phi \pm 0.35 \Phi)+0.42 \times(5.12 \Phi \pm 1.15 \phi)+0.38 \times(8.00 \Phi \pm 1.50 \Phi)$

b) $0.25 \times(4.20 \Phi \pm 0.46 \Phi)+0.45 \times(6.43 \Phi \pm 2.09 \Phi)+0.30 \times(10.38 \Phi \pm 1.38 \Phi)$

c) $0.05 \times\left(2.91 \Phi_{ \pm} 0.51 \phi\right)+0.04 \times\left(5.46 \Phi_{ \pm} 0.33 \phi\right)+0.91 \times\left(7.52 \phi_{ \pm} 1.83 \phi\right)$

d) $0.03 \times\left(2.79 \phi_{ \pm} 0.49 \phi\right)+0.05 \times\left(5.58 \phi_{ \pm} 0.48 \phi\right)+0.92 \times(7.54 \phi \pm 1.79 \phi)$

e) $0.28 \times(3.05 \Phi \pm 0.59 \phi)+0.14 \times(5.56 \Phi \pm 0.61 \phi)+0.58 \times(7.38 \phi \pm 1.82 \Phi)$

f) $0.34 \times(4.14 \phi \pm 1.09 \Phi)+0.01 \times\left(4.78 \Phi_{ \pm} 0.30 \phi\right)+0.65 \times\left(7.61 \Phi_{ \pm} 1.66 \phi\right)$ 
1700] 000 be ca

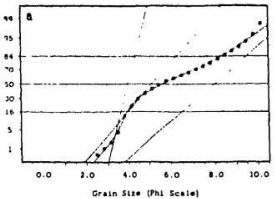

87003.004 $1210 \mathrm{~cm}$

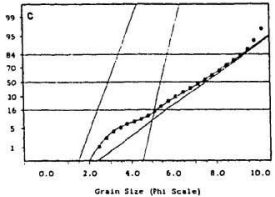

$07003.0041236 \mathrm{ct}$

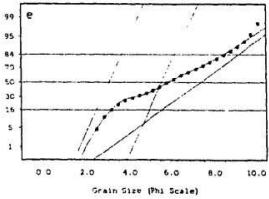

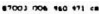

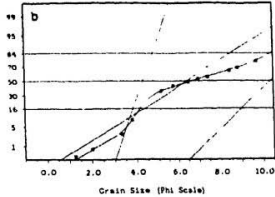

$97003-004$ 1319

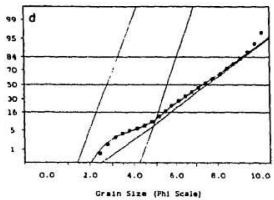

B2003.004 1895 es

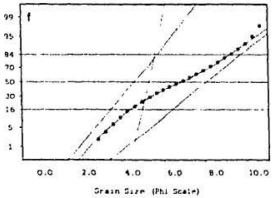


a mean size of about $8 \$$ and a standard devistion of about $1.3 \$$. The fine component dominates the samples from core 004 , comprising $00 \%$ of each sample. The fine, poorly sorted component only comprises $30-70 \%$ of each sample from core 006 , and $10-16 \%$ of samples in core 002 .

A coarse, well sorted population is recognized in Coulter counter samples from core 004, a sieve-hydrometer sample from cores 002, and all samples from core 006 . In one sample from core 002 , this population comprises $7 \%$ of the total population with a mean diameter of $4.7 \phi$ and a standard deviation of $0.45 \phi$. In core 008 , grains of this population comprise $2-30 \%$ of each sample, and have a mean diameter of about $3.8 \Phi$ with a standard deviation of $0.4 \phi$. The coarse, well surted component of core 004 rarely exceeds $10 \%$ of each sample. Grains of this population bave a mean diameter of about $3.0 \Phi$ and a stendard deviation of about $0.6 \Phi$, making it coarser and more poorly sorted than the equivalent population in core 006 . The sand body in core 008, which appears to be a sorted sand similar in character to this population, indicates that this apparent component probably represents a real grainsize population.

A fine, well sorted population is recognized in samples from core 004 and 002. Grains of this population comprise $<5 \%$ of most samples from core 004 , but reach $15 \%$, and have a mean diameter of about $6.0 \phi$ and a standard deviation of $0.5 \phi$. In core 002 , this population comprises $45-75 \%$ of the samples, with a mean diameter of 6.5-7థ and a standard deviation of $0.3 \Phi$. This population must comprise at least $3 \%$ of the sample for it to be resolved because of the compression of the probability axis near a cumulative probability of $50 \%$. Extremely coarse or extremely fine, well 
sorted populations can be resolved even if they comprise $<1 \%$ of the sample because of the expansion of the probability axis at extreme values. At $1470 \mathrm{~cm}$ of core 004, the fine, well sorted population is apparently absent, even though it appears in four other samples within $6 \mathrm{~cm}$ (figure 4.10). In the two neighbouring sampler, this component was at the limit of resolution.

A coarse, poorly sorted population is obtained from the samples in core 006 , from one of the Coulter counter samples of core 004, and from the sieve-hydrometer samples from 004. This population comprises up to $70 \%$ of the sample and has a mean diameter of $4-5 \phi$ and a standard deviation of 1.2-1.5\$ (figure 4.10). This population is the one most likely to be associated with the dispersed gravel and pebbles found in all cores. Schiebe et al. (1983) demonstrated that the differences in the grain size distributions measured on the Sedigraph Particle Size Analyzer and the Computerized Electrozone System (CES) can be explained by the restricted range of the CES. The CES and the Coulter Counter function on the same principle, and have similar range restrictions (Coulter Electronics, 1979; Schiebe et al., 1983). Thus, grain-size data from a sample analyzed on the Sedigraph can be mathematically converted to appear as it would had the analysis been run on the Coulter Counter. A similar method would probably work for the sieve-hydrometer data. Sieve-hydrometer data from $1410 \mathrm{~cm}$ in core 004 indicates the presence of a coarse, poorly sorted population in addition to one well sorted population, but when the data is converted to appear as it would on Coulter Counter, a coarse, well sorted component is observed, along with two fine populations, as in 1464 to 1470 $\mathrm{em}$ in the same core (figure 4.10). The Coulter counter's inability to detect gravel and oarse sand results in increasing the apparent mean and decreasing the 
Figure 4.10. Dissected Coulter counter cumulative curves from core 004 near $1470 \mathrm{~cm}$.

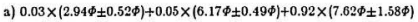
b) $0.05 \times(2.75 \phi \pm 0.55 \phi)+0.04 \times\left(5.70 \Phi_{ \pm} 0.75 \phi\right)+0.91 \times(7.30 \phi \pm 1.80 \phi)$
c) $0.04 \times(2.89 \phi \pm 0.61 \phi)+0.04 \times(6.20 \phi \pm 0.30 \phi)+0.93 \times(7.47 \phi \pm 1.75 \phi)$
d) $0.05 \times(2.99 \phi \pm 0.38 \phi)+0.05 \times(6.48 \Phi \pm 0.40 \Phi)+0.00 \times(7.770 \Phi \pm 1.60 \Phi)$
e) $0.07 \times(2.97 \phi \pm 0.58 \phi)+0.93 \times(7.53 \phi \pm 1.75 \phi)$ 

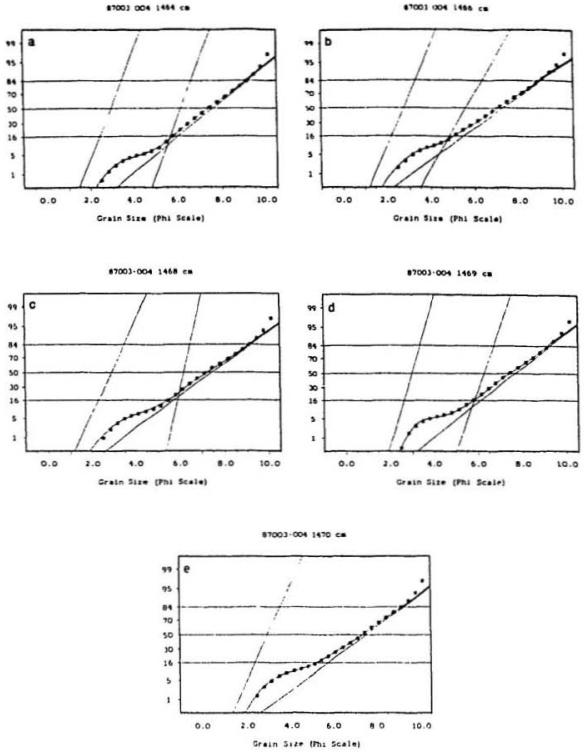
standard deviation of coarse populations. It is probable that the coarse, well sorted component in core 004 Coulter counter samples is an artifact of the instrument, and actually represents a poorly sorted component.

A very fine population is inferred from samples from core 002 , as in both samples, $6-10 \%$ of the sample is finer than $10 \phi$, although very little sediment falls into the last two or three size intervals. These inferred populations cannot be accurately defined, although estimated parameters are used to fit a cumulative curve to the data (figure 4.11). The sieve-bydrometer analyses from 87003 cores show the influence of a very fine, well sorted population, which, in lithofacies 1, has a mean of 8.5 to $8 \Phi$ and a standard deviation $<0.5 \Phi$. This population has not been detected in any of the 86034 samples, even in cores within $2 \mathrm{~km}$ of core 004, nor does it appear in Coulter counter samples from cores 004 and 006.

\section{Genetic Implicstions of component log-normal curves}

The characteristics of the component log-normal populations are nearly constant in each core, so that changes in grain size are related primarily to variations in the relative amounts of each population. If the component log-normal populations represent actual populations each of which have been deposited by a different mechanism, then the location of points plotted from entire samples on a CM texture plot (Passega, 1957) would be a function of mixing rather than depositional mechanism. More useful information is obtained if the dissected lognormal populations are plotted (figure 4.12) against the transport-related fields of Passega (1957). The fine, poorly sorted components of all cores plot near the pelagic sedimentation field, while the coarse, well sorted components plot in the coarse end of the turbidite field. The fine, well sorted log-normal components of 
Figure 4.11. Dissected sieve-hydrometer cumulative curves.

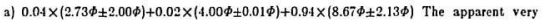
well sorted population (vertical line) results from a break in the data at $4 \Phi$. Sediment coarser than $4 \Phi$ is measured using sieves, while that finer than $4 \Phi$ is measured using hydrometers. Only the two poorly sorted populations represent real populations.

b) $0.03 \times(3.30 \Phi \pm 0.66 \Phi)+0.05 \times(4.95 \Phi \pm 0.35 \phi)+0.92 \times(8.10 \phi \pm 1.60 \Phi) \mathrm{A}$ plot of the preceding sieve-hydrometer data as it might appear had the analysis been performed on the Coulter counter. Note that the coarse, poorly-sorted population has been converted into a coarse, well-sorted population, and that the apparent sorting and the me. grain size of the fine, poorly-sorted component have been increased.

c) $0.29 \times(1.74 \phi \pm 1.05 \phi)+0.45 \times(6.54 \Phi \pm 0.30 \Phi)+0.07 \times(4.70 \phi \pm 0.45 \Phi)+$ $0.10 \times(6.78 \Phi \pm 1.50 \phi)$

d) $0.01 \times(1.42 \phi \pm 0.91 \Phi)+0.05 \times(5.50 \phi \pm 0.22 \Phi)+0.69 \times(7.87 \Phi \pm 1.56 \Phi)+$ $0.25 \times(0.28 \Phi \pm 0.28 \Phi)$

e) $0.03 \times(1.88 \Phi \pm 3.12 \Phi)+0.00 \times(4.85 \Phi \pm 0.60 \Phi)+0.12 \times(0.45 \Phi \pm 0.20 \Phi)+$ $0.76 \times(7.08 \Phi \pm 1.00 \Phi)$

f) $0.15 \times\left(2.00 \Phi_{ \pm} 0.99 \phi\right)+0.16 \times\left(6.50 \Phi_{ \pm} 0.99 \phi\right)+0.63 \times\left(7.18 \phi_{ \pm} 0.28 \Phi\right)$ 
4701 one 14001410 c:

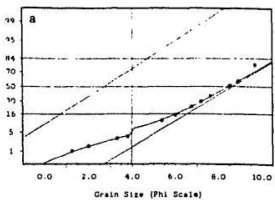

$07003-00255-60 \mathrm{cs}$

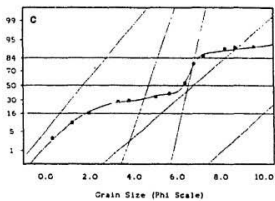

17001.004 $650.660 \mathrm{ce}$

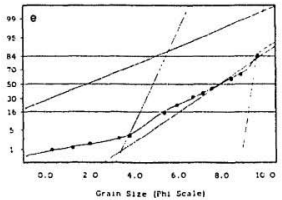

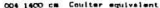

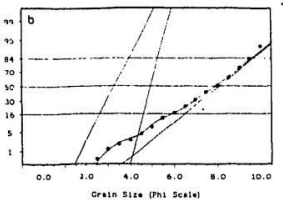

A1003.004:ibto-1023 ca"

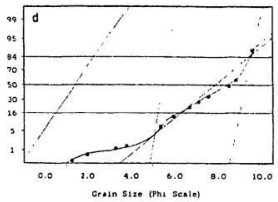

$67003-\infty 02333-336<$

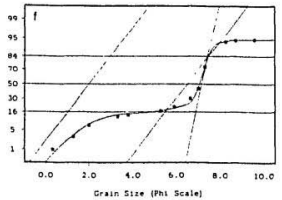


Figure 4.12. CM texture plots (afler Passega, 1957) of dissected log-normal components and total populations of grain-size samples (rom a) core 002, b) core 004, and c) core 006. 

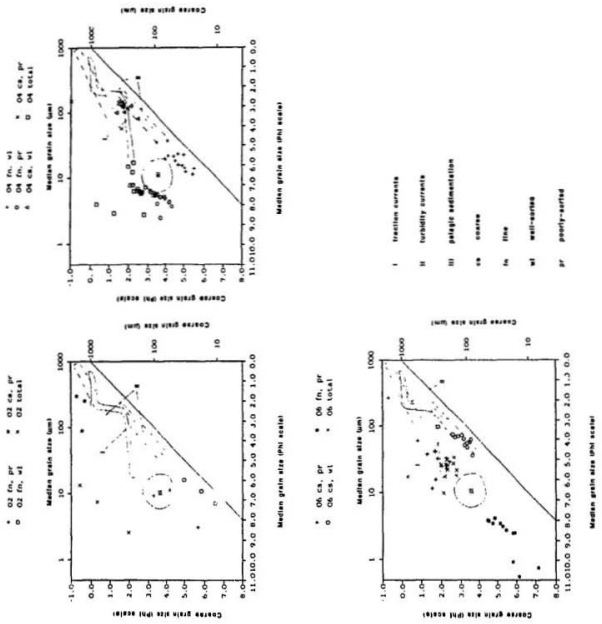
core 004 samples plot in the fine end of the turbidite field, and the coarse, poorly sorted log-normal components of cores 004 and 006 , which plot near to the field of pelagic sedimentation, probably represent ice rafted sediment. The coarse, poorly sorted components from core 002 plot in the turbidite field, as do the fine and coarse, well sorted components.

The data from core 004 suggests that $\mathbf{9 0 - 9 9 \%}$ of sediment from lithofacies 3 , 4 , and 5 is deposited from rain-out processes, with $<10 \%$ due to ice rafting or turbidites (ice rafting generally being of greater importance than turbidites). In core 006 , ice rafting is responsible for $35-80 \%$ of the sediment of lithofacies 2 and 3 , with underflows being nearly as important as rain-out from sediment plumes. The samples from core 002, particularly those from lithofacies 1 , indicate that underflow or storm-wave/tidal current reworking dominate sedimentation, although there is a strong component of suspension rain-out.

\subsection{Sedimentary structures}

\section{Pyritized tubes and bioturbation}

Bioturbation occurs as thin vermicular tubes black with organic material (referred to as "black" bioturbation), and as faintly visible tunnels and chambers filled with light grey or brown soft mud (referred to as "white" bioturbation). Only one type is usually present at any -one place in the cores, but in between 1100 and $1170 \mathrm{~cm}$ in core 004 , both types are present. "White" bioturbation is usually found in lithofacies 1, in the upper part of lithofacies 3, and, rarely, in lithofacies 4 . "Black" bioturbation is abundant in lithofacies 4, the lower part of lithofacies 3, but is very rare in lithofacies 5 . 
Large numbers of vermicular tubes are visible in $x$-radiographs (figure 4.2b). Where recoverable, they are found to be flattened tubes of pyrite and clay minerals. Pyrite forms a microcrystalline aggregate that coats the inner surface of these tubes. These tubes can be straight or sinuous, branching or non-branching. The presence of these tubes corresponds to the absence of the black burrows observed on the split core surface (figure 4.13). Where the black burrows occur, no pyritized tubes are observed, but nodules of goethite and clay minerals are found, which do not appear on x-radiographs (iigure 4.14). The pyritized tubes and goethite nodules comprise the authigenic component of the coarse sand and gravel samples from core 004 . Pyrite is known to oxidize to $\mathrm{Fe}(\mathrm{OH})_{3}$ via a reaction which is strongly $\mathrm{pH}$ dependent when $\mathrm{pH}>5.5$ (Fenchel and Blackburn, 1070) thus the goethite nodules are thought to represent pyrite tubes which have subsequently been oxidized. It is impossible to determine whether the black burrows are enhanced by the oxidation of pyrite or the organisms which form them were restricted to sediments of high $\mathrm{pH}$. Pyritized burrows an burrow fillings are produced by the reaction of iron with dissolved $\mathrm{K}_{2} \mathrm{~S}$ produced by bacterial consumption of organic matter under anserobic conditions (Berner, 1970), and are thought to represent periods of increased meltwater influx (Thomsen and Vorren, 1984).

Distinct alternating bands of bioturbated and unbioturbated muds are observed to grade into alternating bands of heavily bioturbated and sparsely bioturbated muds near the base of lithofacies 4 (figure 4.15). The bioturbated bands are $5-15 \mathrm{~cm}$ thick and characterised by black, vermicular burrows. The unbioturbated bands are $2-10 \mathrm{~cm}$ thick. This banding could be caused by periods of relatively slow and uniform deposition punctuated by episodes of rapid 


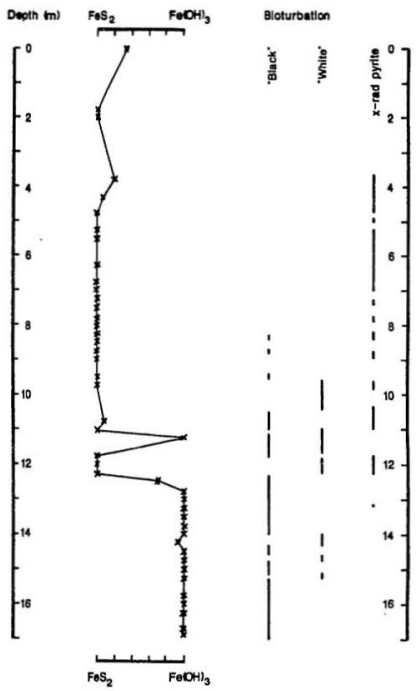

Figure 4.13. Type of authigenic mineral present plotted against depth in core 004, and intervals of "black" and "white" bioturbation, and intervals where pyrite is observed on X-radiographs. 


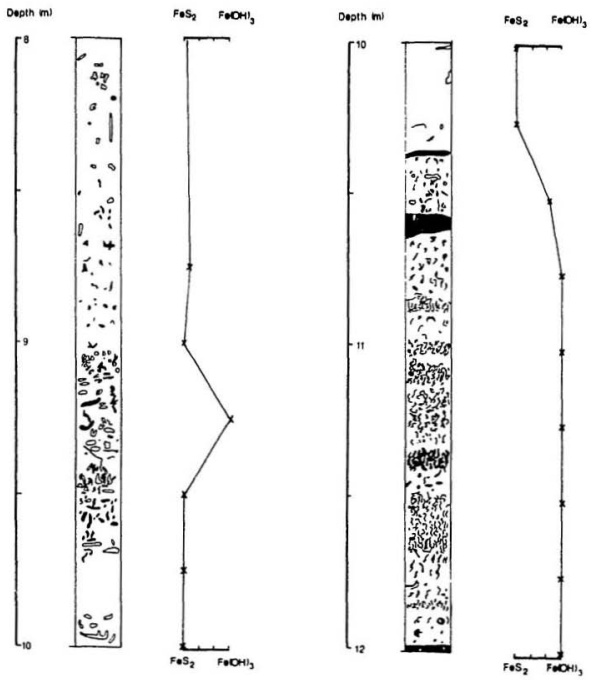

Figure 4.14. Interpreted bioturbation strurtures and type of authigenir mineral present in core 004 for depths of 8 to $12 \mathrm{~m}$. Black stipples reprement - black - bioturbation, unfilled rlened curves fepresent "white" buol urbation. 
Deplin $m)$

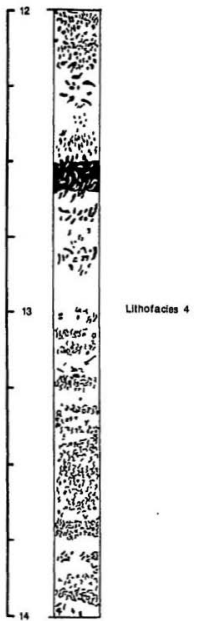

Death $(m)$
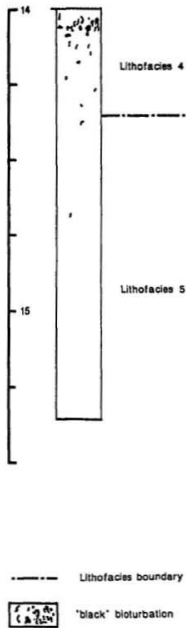

Figure 4.15. Alternating bands of bioturbated and unbioturbated muds at the base of litholacies 4 in core 006 . Bioturbation patterns were interpreted from core photographs between the 12 and $15 \mathrm{~m}$ intervals. 
sedimentation, as observed in front of McBride Glacier in Alaska, which caused sedimentation rates to increase by an order of magnitude (Cowan et al., 1088). Bands of black mud, which are occasionally burrowed, occur further upcore, but are restricted to lithofacies 4. These bands probably represent extreme reducing conditions.

\section{Laminations}

Unlike glacilacustrine sequences, glecimarine sequences are rarely rhythmically bedded because (i) the density of sea water is often greater than turbid meltwater, promoting rain-out from suspension rather than turbidites, (ii) nocculaticn of claysized particles causes them to behave as silt-sized particles, (iii) bioturbation may destroy sedimentary structures (Edwards, 1978; Domack, 11184). Glacimarine rhythmic sediments are probably formed close to the ice margin (Domack, 1084). In brackish waters, clay and silt do not separate thoroughly, and the resulting varves are described as symmict (Edwards, 1978).

Laminations are observed in $x$-radiographs from litholacies 2 in core 006, in lithofacies 3 in cores 023 and 025 , in lithofacies 4 in core 004 , and in litholacies 5 in cores 004 and 023 (figures 4.2c, d). The laminations in the Emerald Silt were chosen for study, and several small grain size samples were chosen from alternating lamina near the base of core 004 . Several Coulter counter analyses were also performed on samples in the laminated section of core 006 , however these samples were not taken lamina by lamina. The grain size data is presented in the section above. At the interval $1600-1696 \mathrm{~cm}$ in core 004 , the laminations are associated with variations in the relative abundance of the coarse, well sorted component, and the occurrence of a coarse, poorly sorted component in the cosrsest lamination. 
Laminations in core $\mathbf{0 0 6}$ are associated with variations in the abundance of the three components determined above. Laminations may be the result of changes in iceberg flux, with coarse laminations resulting from an increased supply of coarse ice rafted material during periods of increased calving, or of changes in the meltwater flux, with fine lominations resulting from an increase in meltwater at the ice margin suspending more sediment in the water column. Such changes may be seasonal or storm-related.

\section{Gravelly and sandy horizons}

Horizons of gravelly and sandy mud $10-20 \mathrm{~cm}$ thick are found in lithofacies 4 (figure 4.2e). These are apparently ungraded, and matrix supported. As ice rafting is established as being the mechanism responsible for gravel (chapter 4.3), these bands either represent iñcreased influx of ice, or material dumped by the overturning of icebergs. As iceberg berm thicknesses are observed to be up to $2 \mathrm{~m}$ thick, these horizons probably do not represent berms. Overturning of icebergs, however, may result in coarse deposits (Drewry and Cooper, 1881). This material may form a deposit consisting of a lenticular body of gravel enclosed by muds if if the water is shallow and the iceberg releases the material sitting on its upper surface suddenly, by overturning or breaking (Ovenshine, 1070). 


\section{Biological Data}

\subsection{Macrobenthos}

On the basis of bivalve mollusc, gastropod, and scaphopod shells recovered in cores from Emerald Basin or identified in core $x$-rndiographs, four macrobenthic assemblages are defined. Because the number of valves recovered is small, and the sample sizes are inconsistent, no numerical or statistical methods are used to determine the signifieance of each assemblage. Key shells have been identified by F. E. Cole at Atlantic Geoscience Centre; subsequent specimens have been identifird by the author.

i) Assemblage Ml consists of small numbers of frngments, primnrily of Yoldia hyperborea Torrel, and is restricted to lithofacies 5 and the base of litholacies 4. There is a gradual transition upcore to overlying assemblage M2.

ii) Assemblage M2 is dominated by articulated Portlandia arctica (Cirny) valves, with minor occurrences of single valves and fragmenta of $\underline{Y}$. hypreborra, is restricted to lithofacies 4 and the base of lithofacies 3 , and is probably equivnlent to the 'pioneer Portlandia assemblage' of Syvitski et al. (in press).

iii) Assemblage $M 33$, a more diverse assemblnge than $M 2$, is dominnted by $\underline{\underline{L}}$. arctica with lesser numbers of Macoma calcarea (Gimclin), Nuculn tenuin (Montagu). Nucula delphinodonta Mighels and Adams, and Nuculnna pernula (Muller). This assemblage is generally found in sediments of lithofncies 2 and 3, and in protrably equivalent to the 'mature Portlandin assemblage' of Syvitaki at al. (in prens). 
iv) Assemblage M4 is dominated by scaphopods of the genus Siphonodentalium Sars, and is generally restricted to lithofacies 1. Also present are valves of $\underline{N}$. pernula, $\underline{N}$. tenuis, $\underline{N}$. delphinodonta, and Astarte subaequilatera (Sowerby).

The lack of well-preserved mollusc shells in the nssemblage M1 implies that conditions during the deposition of lithofacies 5 were unsuitable for molluses. In addition, the presence of worn bivalve shells suggests that there is a component of reworked marine sediment in lithofacies 5 .

The earliest in situ molluscs observed are individual $\underline{\mathbf{P}}$ arctica specimens of assemblage M2 in lithofacies 4. Spjeldnaes (1978) demonstrates that while $\underline{P}$.

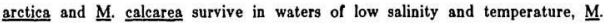
calcarea is a superior competitor, and tends to dominate under optimum conditions, while $\underline{P}$ arctica dominates when salinities fluctuate and waters are very turbid, because of the reduced predator load under such conditions. The $\underline{\mathbf{P}}$ arctica valves recovered from Emerald Basin are much larger than those recovered from the present day Beaufort Sea (Wagner, 1977), and are approximately the same size as fossil valves recovered near Oslo Fjord (Spjeidnaes, 1978). Other examples of molluses reaching unusual sizes due to a low predation load include the largest known specimens of Crassostrea virginica (Gmelin) recovered from the shell middens

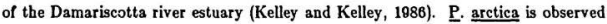
to colonize sediments within 25 years of glacial retreat (Gilbert, 1082). The Portlandia assemblage like the 'pioneer Portlandia assemblage' (Syvitski et al., in press), probably represents colonization near an ice margin, possibly within decades 
of glacial retreat, when considerable suspended material from sediment plumes and ice rafting would be expected.

Assemblage M3 demonstrates higher faunal diversity than assemblage M2. Small $\underline{P}$.arctica valves are better represented. There are occasional colonies located in the cores; one in core $\mathbf{0 0 6}$, dominated by $\mathrm{P}$. aretica and sampled extensively, and another in core 004, apparently dominated by $\underline{\mathrm{P}}$ arctica and $\underline{N}$ delphinodonta (figures $5.1 \mathrm{a}, \mathrm{b}$ ). As the ice margin retreats, the supply of meltwater decrenses, lowering the suspended sediment load, stabilizing salinity, increasing faunal diversity, and ending the dominance of $\underline{\underline{P}}$ arctica (Syvitski et $\underline{\text { nl. }}$, in press).

Syvitski et al. (in press) prediet an assemblage dominated by filter-ferding molluses during the last stage of deglaciation of Arctic fjords, while sediment lond is minimized. Assemblage M4 of Emerald Basin is probably analogous to the 'Ophiurid assemblage' of Syvitski et al. (in press). Scaphopods (figure 5.Ic) live on the seafloor, partially embedded in mud or sand, and feed on benthic for aminifera and other sinhilài uıḡnisms, Mushing wastes through an apical aperature protruding above the seafloor (Pojeta, 1987). As the flushing of products is probnbly mont efficient when the water is low in suspended sediment, this assemblage indienten a further decrease in sediment meltwater plumes and ice rafted debris.

\subsection{Mierofosoils}

Five cores in Emerald Basin have been studied by previous workers. Foraminiferal studies have been carried out in cores 008 and 000 (Vilks and $\mathbf{R}$ anhid. 1075; 1878), 020 (Mudie, 1880; Scott et al., 1084), 012 (King and Fader, 19k8), and core 004 (Lewis et al., 1988; Miller, pers. comm., 1088). Vilks and Rashid (1078) 

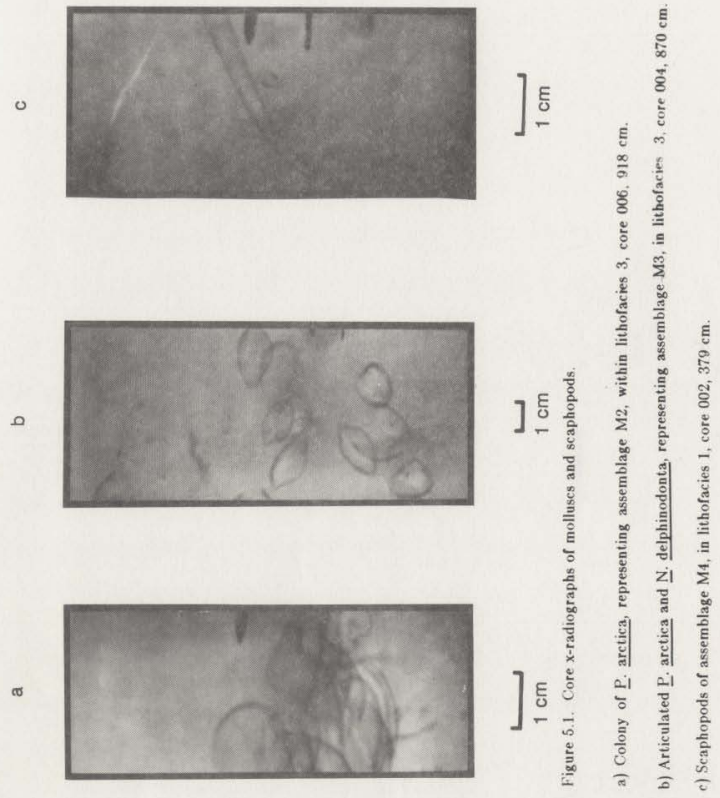
calculated faunal diversity index values using the information function $H(s)=-\sum_{i=1}^{n} p_{j} \ln p_{i}$ (Buzso, 1972). $H(s)$ is the diversity index value, and $p_{i}$ is the relative amount of the $i^{\text {th }}$ species $\left(0 \leq p_{i} \leq 1\right)$. From the table in Scott et al. (1984), foraminiferal diversity index values have been calculated. As of this writing, full identification tables are not available for either of cores 012 or 00.1. Palynological work has been carried out in cores 008 (Mudic, 1980), and on 020 (Mudie, 1980; Scott et al., 1984).

\subsubsection{Benthle foraminifera}

On the basis of samples from the composite of cores -008 and -009 , and cores 87-003-004 and 77-002-020, thece benthic foraminiferal assemblages are reengnized.

(i) Assemblage $\mathbf{F} 1$ is moderately diverse, and consists of $\underline{\mathbf{E}}$. excavntum. (:.

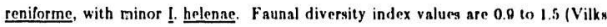
and Rashid, 1976).

(ii) Assemblage F2 is characterized by low taunal diversity index valuen 1 0.1) with E excavatum comprising Ra-ag": of benthonic foraminifural teste (Vilks and Rashid, 1978; Lewis 느 al.. 1988).

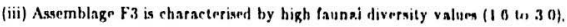

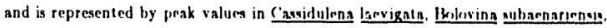
Bulumina sculeata, and Buluming marginata. Faunal divernity indrx ralura increase upward (bilks and Rashid, 1070), and the number of benthe epeeries

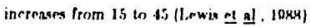




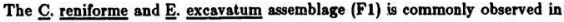
sediments from the Labrador Shelf to the Gulf of Maine, and is characteristic of glacimarine sediments in northern Europe (Scott et al., 1984). This fauna represents a "warm" ice margin-one where the ice margin is melting (Scott and Medioli, 1980). No modern analogue for this assemblage is known (Scott et al., 1984). This assemblage is noted at the base of cores 004 , and 009 , as well as at a depth of about $5 \mathrm{~m}$ in core 004, where it is thought to indicate an influx of Laurentide meltwater discharged through the St. Lawrence Valley (Lewis et al., 1988). It can be correlated roughly to molluse assemblage M1 (figure 5.2).

The E. excavatum assemblage (F2) is observed in all of the cores from Emerald Basin. It is also observed in cores from Country Harbour moraine and the Gulf of Maine (King and Fader, 1986), and the Labrador Shelf (Josenhans et al., 1986). This assemblage represents estuarine conditions, with salinities probably lower than 25 per mil (Vilks and Rashid, 1976). Schnitker (1976) suggests that such a fauna may be indicative of turbid waters, where sediment rates would be high and salinities would fluctuate. The exclusion of other foraminiferal species in assemblage F2 may be a function of fluctuating salinity as opposed to low salinity. Assemblage F2 corresponds roughly to mollusc assemblage M2 and the lower part of assemblage M3 in core 004 (figure 5.2), both of which contain $\underline{P}$. arctica valves in large number.

Increasing species diversity in assemblage F3 represents a change from estuarine conditions with fluctuating salinities toward a normal marine environment (Vilks and Rashid, 1976). The peak in E. excavatum tests noted in core 020 is 
Figure 5.2. Correlations betwern lithofacies, and faunal awomblaxes in limerald Hasin The pollen assemblage boundaries do not reftelate with the dinuflaxellate and foraminiferal assemblage beundaries between eores 020 and $00 x$. 

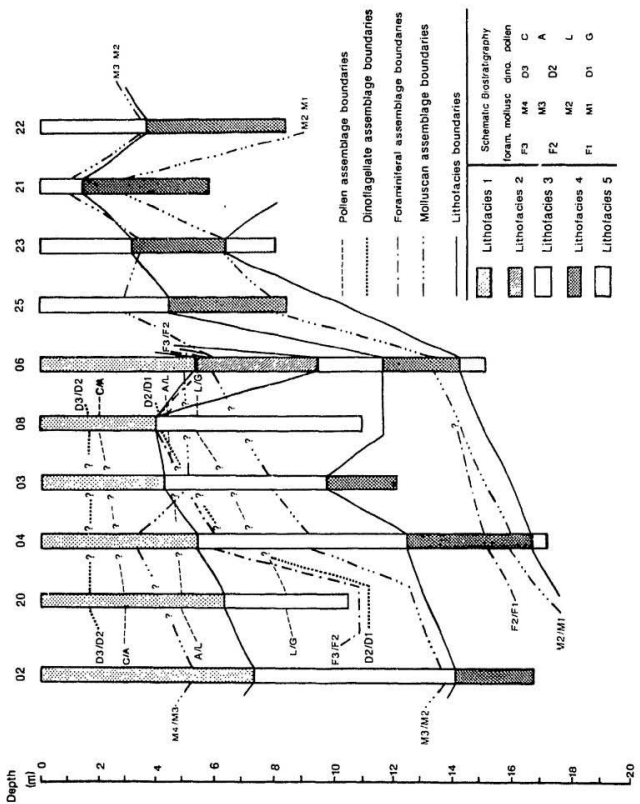
probably due to reworking of sediments rich in this species (Scott et al., 1084). Modern sediments in the southern half of Emerald Basin, as well as in the seaward approaches to the Basin are rich in E. excavatum tests; however their worn appearance and the complete lack of living specimens indicates that they are reworked (Williamson et al., 1984). This assemblage roughly correlates with macrobenthic assemblage M4 (figure 5.2).

\subsubsection{Dinoflagellates}

On the basis of dinollagellates from cores 020 and 008, Mudie (1080) recognized three dinocyst assemblages. (i) Assemblage D1 is defined by low dinocyst concentrations, low diversity, the absence of cysts common in modern sediments, and the presence of freshwater taxa. (ii) Assemblage D2 is defined by a large increase in the number of cysts, including Peridinium species, an increase in $\underline{\mathrm{O}}$. centrocarpum, and the presence of Spiniferites species (iii) Assemblage D3 is defined by large numbers of Quaternary dinoflagellates, and dominated by Peridinium conicoides with decreased numbers of Operculodinium centrocarpum and minor amounts of Spiniferites species.

Dinocyst assemblage D1 is similar to that found in turbid water basins of upper Bay of Fundy. The presence of freshwater taxa indicates low salinities or a supply of freshwater into Emerald Basin (Mudie, 1880). This assemblage can be correlated to foraminiferal assemblage F2 and mollusc assemblage M2 (figure 5.2).

Assemblage D2 represents water temperatures similar to those of today (Mudie, 1980). The number of cysts in assemblage D2 declines downward in core 020 (Mudie, 1980), corresponding to the increasing importance of E. excavatum. 
Assemblage D2 corresponds with the lower part of foraminiferal assemblage F3 and mollusc assemblage M3 (figure 5.2).

Assemblage D3 is similar to present-day surficial assemblages, but also includes continental slope fauna (Mudie, 1980). This assemblage is correlatable to foraminiferal assemblage F3 and mollusc assemblage M4 (figure 5.2).

\subsubsection{Pollen and spores}

On the basis of pollen samples from cores 020 and 008, Mudie (1080) defined four pollen assemblages: (i) zone G, defined by the presence of Arctic herb pollen taxa, (ii) zone $\mathrm{L}$, a spruce-birch-shrub tundra assemblage, (iii) zone A, a spruce-pinefir pollen assemblage, with decreased representation of shrub tundra pollen, (iv) zone $\mathrm{C}$, a spruce-hemlock-oak-birch assemblage, including temperate deciduous tree pollen taxa, indicating a mixed deciduous-boreal forest vegetation,

Pollen and spore zone $\mathrm{C}$ represents conditions similar to the present day, zone A represents the post-glacial to early Holocene interval, and pollen zones $\mathbf{L}$ and $\mathrm{G}$ represent late-glacial palynofacies (Mudie, 1980). The presence of herb pollen taxa in pollen and spore zone G, which are not adapted for long-distance transport, implies that even during glaciation, there remained ice-free refuges near Emerald Basin (Mudie, 1980).

Correlation of the pollen assemblages to the foraminiferal assemblages of cores 008 and 020 is not as straightforward as the correlation of the dinoflagellate and foraminiferal assemblages (figure 5.2). The polien stratigraphy for core 008 appears to be consistent with the implied environment of the dinoflagellate and foraminiferal 
assemblages of the same core, with glacial vegetation corresponding to turbid waters of low salinity, whereas in core 020 , pollen zones $\mathrm{L}$ and $\mathrm{G}$ correspond with warmer water dinoflagellates, and less turbid water foraminifera. As the two core sites are so close together, the pollen zones would be expected to be time-synchronous, indicating that the foraminiferal and dinoflagellate assemblages are timetransgressive (Mudie, 1980). However, it is unreasonable for the surface water conditions to have been time-transgressive over the distance between the two cores, and there appears to be some inconsistency in the dinoflagellate and pollen stratigraphies of cores 008 and 020 . 


\section{Chronology and core correlation}

\subsection{Correlation of cores to seismic records}

Positioning the core within the acoustic stratigraphy is done by correlating changes in geotechaical properties or lithological parameters of the core to reflection events. All cores are positioned in the scoustic stratigraphy assuming a constant velocity of $1470 \mathrm{~m} / \mathrm{s}$, which is typical of velocities measured in cores from $\mathbf{8 7 - 0 0 3}$ (Mayer, pers. comm.) (figure 6.1).

\subsection{Radiocarbon dates}

A total of 23 radiocarbon dates are available from Emerald Basin, of which 13 are accelerator mass-spectrometer (AMS) dates from shell material (table 6.1), and 10 are obtained from total organic matter (TOM) (table 6.2). All dates are less than $20 \mathrm{ka}$, with the exception of two of the TOM dates from core 012 (King and Fader, 1986). Contamination by reworked organic material increases the radiocarbon derived age of organic matter (Nambudiri et al., 1980; Fillon et al., 1981). Although techniques have been suggested to correct for contamination (Nambudiri et al., 1880), TOM dates must be interpreted with caution.

All AMS shell dates from Gipp and Piper (1989) were taken from fresh-looking valves which were either articulated, or for which matching valves could be found. As the valves of these shells tend to separate easily, it is unlikely that they have been transported. 


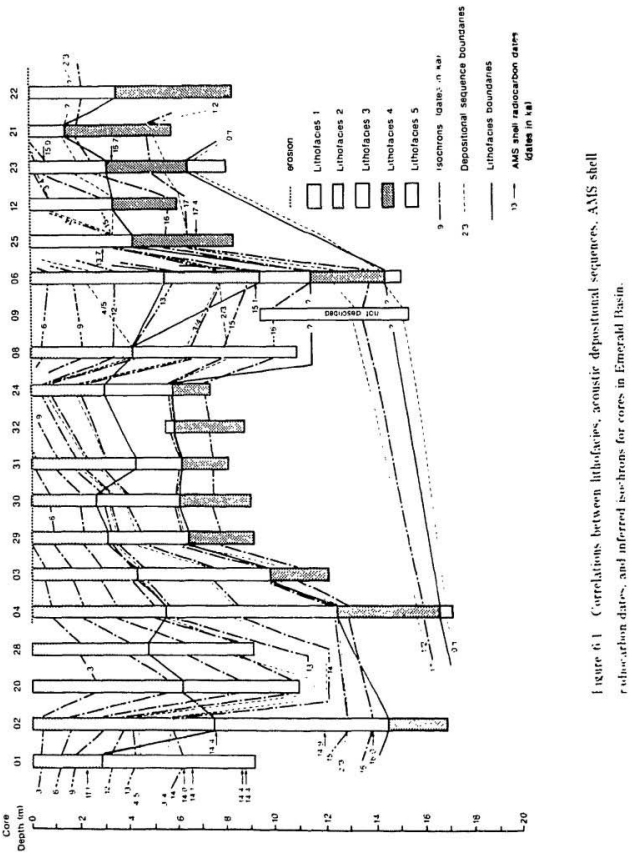


Table 6.1: Shell AMS Radiocarbon dates

\begin{tabular}{|c|c|c|c|c|}
\hline Core & $\begin{array}{l}\text { Interval } \\
\text { (cm) }\end{array}$ & $\begin{array}{c}\text { Depositional } \\
\text { sequence }\end{array}$ & Lab number & Age ( $\mathrm{g} B \mathrm{BP})$ \\
\hline 001 & $221-223$ & 5 & TO-93 & $11140 \pm 120^{1}$ \\
\hline 001 & 608 & 3 & $\mathrm{TO}-91$ & $14050 \pm 140^{1}$ \\
\hline 001 & $659-662$ & 3 & TO-90 & $14130 \pm 90^{1}$ \\
\hline 001 & $868-870$ & 3 & TO-89 & $14440 \pm 180^{1}$ \\
\hline 001 & $874-876$ & 3 & T0-88 & $14360 \pm 170^{1}$ \\
\hline 002 & 754 & 3 & Beta 22229 & $14430 \pm 300^{2}$ \\
\hline 002 & 1190 & 3 & Beta 22235 & $14870 \pm 280^{2}$ \\
\hline 002 & 1380 & 2 & Beta 22231 & $16000 \pm 320^{2}$ \\
\hline 006 & 922 & 2 & Beta 22236 & $15060 \pm 310^{2}$ \\
\hline 023 & 60 & 3 & Beta 20737 & $14960 \pm 240^{2}$ \\
\hline 023 & 339 & 2 & Beta 20735 & $16690 \pm 310^{2}$ \\
\hline 025 & 292 & 4 & Beta 20736 & $13740+220^{2}$ \\
\hline 025 & 681 & 1 & Beta 20738 & $17380 \pm 300^{2}$ \\
\hline
\end{tabular}

Table 6.1. Shell AMS radiocarbon dates from Emerald Basin cores.

${ }^{1}$ D. Scott, pers. comm., 1989

${ }^{2}$ Gipp and Piper (1989) 
Table 6.2: TOM radiocarbon dates

\begin{tabular}{|c|c|c|c|c|}
\hline Core & $\begin{array}{l}\text { Interval } \\
\text { (cm) }\end{array}$ & $\begin{array}{c}\text { Depositional } \\
\text { oequence }\end{array}$ & Lab number & $A_{g} \in(\mathrm{g} B P)$ \\
\hline 008 & $150-192$ & 6 & $*$ & $7180+120^{1}$ \\
\hline 008 & $350-392$ & 5 & $*$ & $7730 \pm 100^{1}$ \\
\hline 008 & $1050-1092$ & 2 & * & $16290+280^{1}$ \\
\hline 012 & $30-60$ & 4 & $6 X-8547$ & $\begin{array}{c}20750+1200^{2} \\
-1050\end{array}$ \\
\hline 012 & $190-220$ & 3 & $G X-8548$ & $\begin{array}{c}17715+800^{2} \\
-600\end{array}$ \\
\hline 012 & $425-455$ & 2 & Csc-3251 & $35000 \pm 1600^{2}$ \\
\hline 012 & $570-600$ & 2 & GSC-3244 & $27300 \pm 600^{2}$ \\
\hline 020 & $200-225$ & 5 & RL-1110 & $10100 \pm 300^{3}$ \\
\hline 020 & $400-425$ & 5 & $R L-1111$ & $11500 \pm 300^{3}$ \\
\hline 020 & $675-695$ & 5 & $\mathrm{RL}-1112$ & $12100+380^{3}$ \\
\hline
\end{tabular}

Table 6.2. TOM radiocarbon dates from Emerald Basin.

*radiocarbon dating provided by Teledyne Isotopes

${ }^{\perp}$ Vilks and Rashid (1976)

${ }^{2}$ King and Fader (1086)

${ }^{3}$ Mudie (1980) 


\subsection{Dating the acoustic stratigraphy}

In defining depositional sequences, it is usually assumed that if the unconformable reflection is time-transgressive, the difference in age along the reflection is small compared to the length of the depositional hiatus represented by the reflection. Radiocarbon dates, as summarized in table 6.3, provide dates for the acoustic stratigraphy.

On the basis of the first occurrence of European pollen at a depth of $20 \mathrm{~cm}$ in the trigger weight core of core 020 (Mudie, 1980) and the entimated age of the base of d.s. 5 (table 6.3), a sedimentation rate of $1 \mathrm{~m} / \mathrm{ka}$ is estimated for d.s. 5 . The sedimentation rate cannot be calculated for d.s 4 as there is only one date in this sequence. On the basis of (i) two dates from core 002, $4.4 \mathrm{~m}$ apart and differing by 440 years and (ii) four dates from core 001 , a sedimentation rate of $10 \mathrm{~m} / \mathrm{ka}$ is estimated for d.s. 3. On the basis of the estimated ages of depositional sequence boundaries and the observed thicknesses, a sedimentation rate of $5-15 \mathrm{~m} / \mathrm{ka}$ is inferred for d.s. $2,2-10 \mathrm{~m} / \mathrm{ka}$ for d.s. 1 , and $>20 \mathrm{~m} / \mathrm{ka}$ for d.s. 0 . 
Table 6.3: Chronology of the acoustic stratigraphy

\begin{tabular}{ccc}
$\begin{array}{c}\text { Depositional } \\
\text { Sequence }\end{array}$ & $\begin{array}{c}\text { Age range of bounding reflections (ka) } \\
\text { Lorer boundary }\end{array}$ & $\begin{array}{c}\text { Upper boundary } \\
\text { Und }\end{array}$ \\
\hline 5 & 13 & 13 \\
4 & 14 & $14-14.2$ \\
3 & $14.4-15$ & $14.8-16$ \\
1 & 17 & 17 \\
0 & 17.4 & 17.4 \\
\hline
\end{tabular}

Table 6.3. Age of depositional sequence boundaries as determined from AMS radiocarbon dates. 


\section{Seismic Features}

Small-scale seismic features are found restricted to specific areas or to specific Gepositional sequences. Erosion fealures are recognized at three stratigraphic levels: at the seafloor, within depositional sequences 4 and 5 , and within depositional sequences 1 and 2. Depositional features are observed at two levels: at the base of depositional sequence $\mathbf{0}$, and within depositional sequences $\mathbf{0 , 1}$, and 2 .

\subsection{Erosion features at the seafloor}

Seafloor depressions varying from 15 to $400 \mathrm{~m}$ in diameter and 1 to $20 \mathrm{~m}$ in depth are identified from seismic records obtained in Emerald Basin (figure 7.1). These features, referred to as pockmarks, appear on sidescan sonograms as sharply defined cone shaped depressions without raised edges, often elliptical, with irregular perimeters (King and MacLean, 1970; Josenhans et al., 1978; Hovland et al., 1984). Their size and distribution are primarily controlled by the sediment type in which they occur (Josenhans et al., 1978). For instance, in Emerald Silt, pockmarks average $55 \mathrm{~m}$ in diameter and $4 \mathrm{~m}$ in depth, with a maximum depth of about $6 \mathrm{~m}$, whereas those in LaHave Clay are $150 \mathrm{~m}$ in diameter and $10 \mathrm{~m}$ deep (Josenhans et al., 1978). They are interpreted as the escape structures of gas leaking upwards from underlying hydrocarbon generating bedrock, slowly growing by the accumulation of large numbers of "unit pockmarks" (Hovland et al., 1984). Because gas can escape around coarse grains without disturbing the sediment, pockmarks are generally not recorded in coarse sediment (Josenhans et al., 1978).

The distribution of pockmarks in Emerald Basin is found to be independent of water depth (figure 7.2). As no systematic variation in pockmark occurrence with 


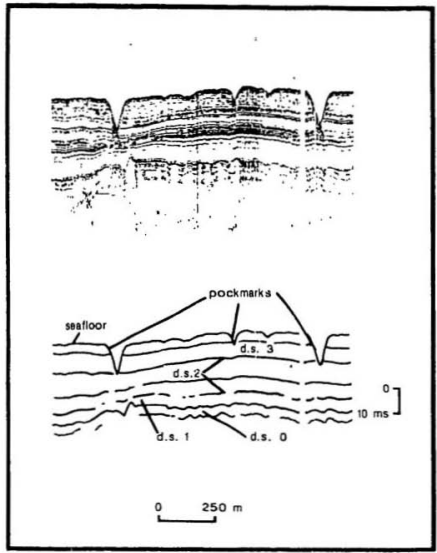

Figure 7.1. Intetpreted NSRFC: V-fin eparket profile aeat the easkern nant of Finetald Basin. Illustrating ourfirial perk mark. Recerd appearn by permuseno of NSlifC 


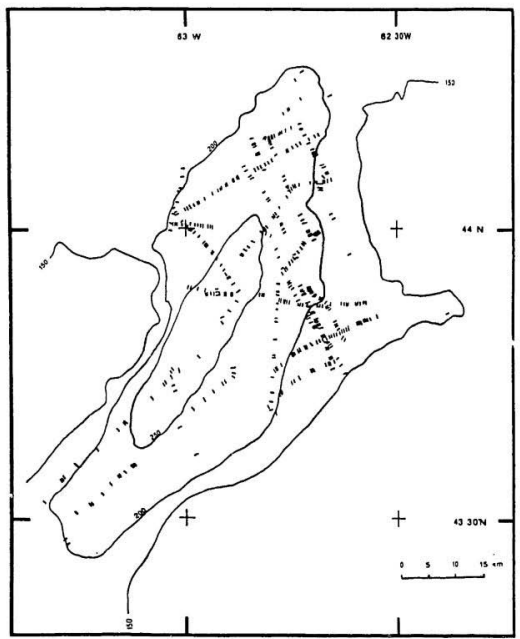

Figure 7.2. Map showing the distribution of surficial pockmarks, as observed on acoustic profiles, plotted on a map of the present-day bathymetry. Contours in $\mathrm{m}$ b.s.l. 
seismic line orientation is observed, the pockmarks are not distributed along lines of preference.

\subsection{Erosion features in depositional sequences 4 and 5}

Subsurface erosion features 1-2 $\mathrm{m}$ deep and up to $40 \mathrm{~m}$ wide, restricted to d.s. 4 and 5, are observed in high resolution acoustic profiles from Emerald Basin (figure 7.3). Apart from their small size range, they are morphologically similar to surficial pockmarks, and are interpreted as buried relict pockmarks (Josenhans et al., 1978).

Buried pockmarks appear to be restricted to water depths greater than $220 \mathrm{~m}$, probably due to the restricted occurrence of depositional sequences 4 and 5 rather than some depth control mechanism (figure 7.4). Because the number of these features encountered per unit distance (referred to as "linear density" hereafter) does not systematically vary with seismic line orientation, it is concluded that they are not preferentially oriented linear features. The distribution of the features has the form of a collection of either randomly distributed point features, or randomly oriented linear features.

There are very few possible mechanisms that will form linear features with apparently random orientation. Ice scour direction is teontrolled by bathymetry (Todd et al., in press). No evidence of faulting has been observed in the Quaternary sediments of Emerald Basin, so the features would not be expected to lie nlong faults. The feeding scours of grey whales that have been detected on the Alaskan Shelf are only up to 2 metres wide and a few $\mathrm{cm}$ deep (Nelson at al., 1987), which are much smaller than the observed features in Emerald Basin. 


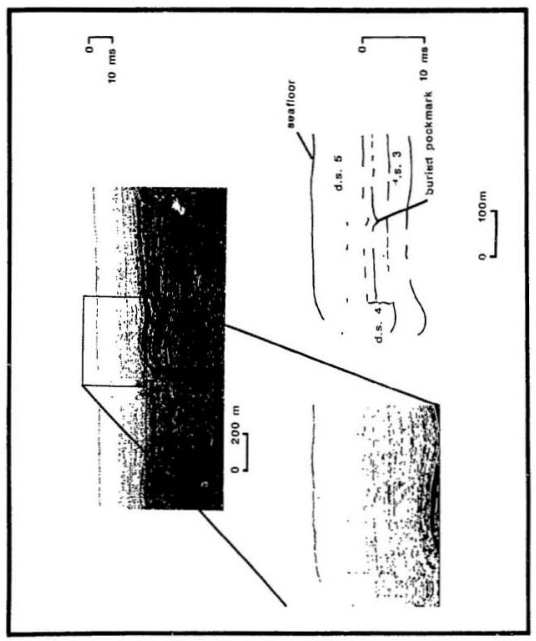

Figure 7.3. Interpreted Huatec DTS profile showing a buried pockmark at the base of depositional sequence 5 . 


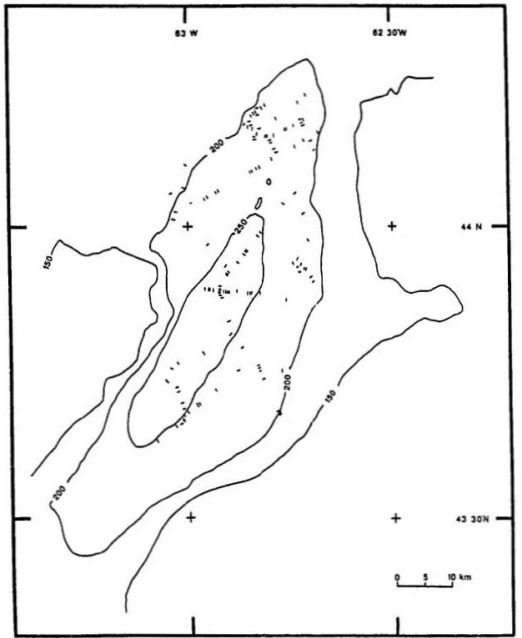

Figure 7.4. Map showing the distribution of buried pockmarks, as observed on acoustic profiles, plotted on a map of the present-day bathymetry of Emerald Basin. Contours in m b.s.l. 
The fact that buried pockmarks are smaller in size than those at the surface, and that they grew through the gradual accumulation of "unit pockmarks", it follows that they formed in a shorter time than those at the surface. Paleosurfaces containing buried pockmarks may represent a depositional hiatus during which many such features accumulated (Hovland et al., 1984) or a paleoseismic event. But if pockmarks grow steadily during sedimentation, then periodic increases in sedimentation rate might fill them in unless their supply of gas is sufficient to prevent it. They would pessibly erode slowly downwards into older sediment, so that the deepest reflection event cut by a pockmark represents its maximum possible age. The large surficial pockmarks, then, have been accumulating over 14 ka. If this model is correct, then the buried pockmarked horizons may represent increased influx of sediment rather than depositional hiatuses, and can only occur when the sedimentation rate is sufficiently low to allow pockmarks to grow. In support of this interpretation, inferred sedimentation rates in depositional sequences 4 and 5 , the pockmarked sequences, are 5-10 times lower than those in depositional sequence 3 , in which there are no buried pockmarks (figure 7.5).

\subsection{Buried features in depositional sequences 1 and 2}

Buried erosion features which cut into underlying reflections are observed between the base of depositional sequence 1 and the upper half of depositional sequence 2 (figure 7.6). They are typically 2 to 5 metres deep (crest to trough), and 30 to 120 metres wide. Although the characteristics of these features appear to be generally similar to those of the surficial pockmarks, there are important differences: 


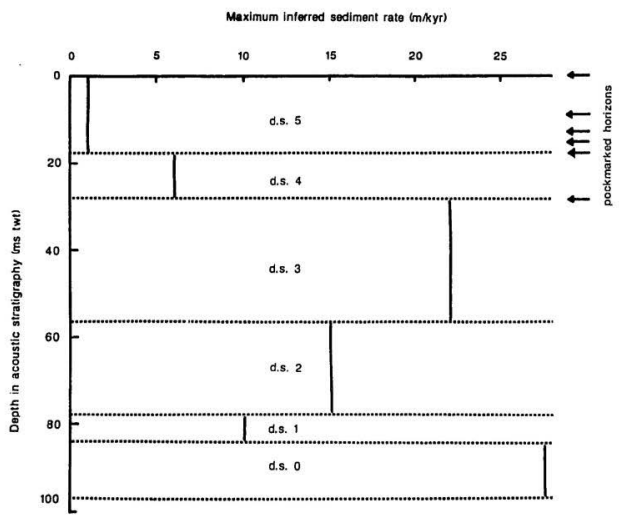

Figure 7.5. Generalized figure comparing sedimentation rates to the occurrence of buried pockmarks. Buried pockmarks are observed at the base of depositional sequence 4 , at the base of depositional sequence 5 , within depositional sequence 5 , and at the sealloor. 


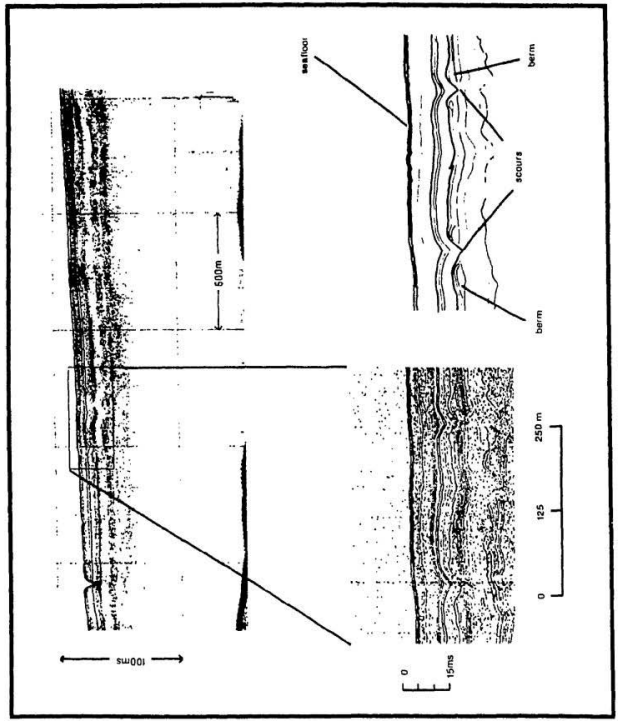

Figure 7.6. Interpreted NSRFC V.fin sparker profile ofar the eastern naak of Emerald Basin, showing features interpreted as buried iceberg scours. Note the presence of berms on either side of the scours, and the lack of noticeable indentation at the present-day seafloor, 
(i) Some of these erosion features exhibit raised edges and asymmetrical deposits at their peripheries, which are not observed in pockmarks (figure 7.6).

(ii) The plot of buried features and paleobathymetry shows that the erosion features are restricted to the basin flanks and are absent in the basin deeps (figure 7.7). There is no depth limitation for surficial pockmarks (figure 7.2).

(iii) On the eastern and southwestern flanks of the basin, the frequency of buried erosion features detected in north-south running seismic lines is greater than that in sast-west running seismic lines (figure 7.8). This implies that they are orien'ed linear features, trending E-W, because the frequency of detection of orifnted linear features increases with increasing angle to the transverse line. Pockmarks, however, are point erosional features. Elongation of pockmarks has been observed by Josenhans et al. (1978), but for point features to have an apparent linear distribution, they would have to occur along nearly parallel lines. Such a distribution has not been observed in Emerald Basin.

iv) $\mathrm{X}$-radiographs of cores $021,023,025,004$, and 000 indicate the presence of disseminated gravel in depositional sequences 0,1 , and 2. Pockmarks are observed in fine-grained sediment, and are absent in gravelly muds (Josenhans et al., 1978).

The differences outlined above suggest that the erosion features of depositional sequences 1 and 2 are linear scours exhibiting depth iimitations and a preferred orientation. The available seismic lines crossing the linear scours allow the direction of the preferred scour orientation to be calculated. Figure 7.9 illustrates a deterministic solution for the average orientation of a linear scour population. For 


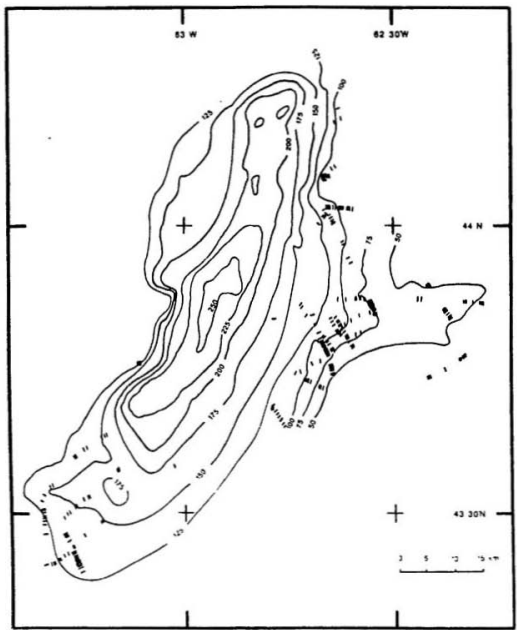

Figu, 7.7. Paleobathymetric map of the top of deposttional sequence 1 sbowing the distribution of buried scours, as observed on acoustic profiles from Emerald Basin. Scours are concentrated in the southern ead, along the eastern fank, and within the eastern channel. Contours in $\mathrm{ms}$ twt below a datum plase $110 \mathrm{~m}$ b.s.l. 


\section{9}

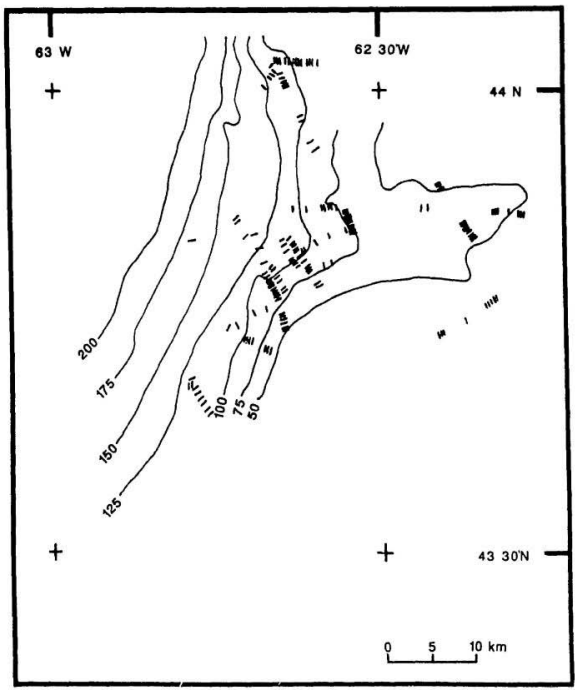

Figure 7.8. Falargement of figure 7.7 on the eastern flank near the eastern channel Scours near the chanoel are concentrated an ansamir lines eunding agperiximately N.S, and are less cornmon on lises running $\mathrm{E}-\mathrm{W}$. 


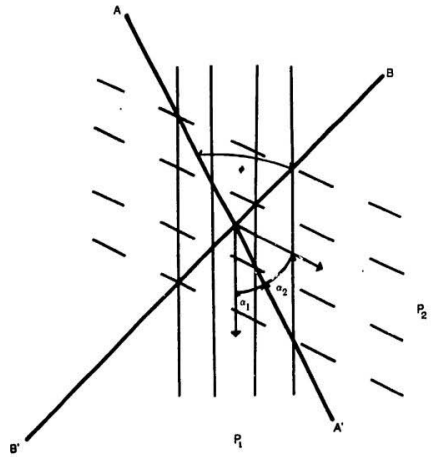

Figure 7.9. Explanation of terms used in calculation of scour orientations from seismic data. Both population 1 and population 2 will cause the same pattern of scours on seismic lines $\mathrm{AA}^{\prime}$ and $\mathrm{BB}^{\prime}$, resulting in two possible solutions, oriented from line $\mathrm{AA}^{\prime}$ by angles $\psi_{1}$ and $\alpha_{2}$. For a pattern of scours on two intersecting seismic lines, there are two possible solutions, which together are referred to as a solution-pair. 
any combination of linesr densities messured on two intersecting seismic lines, two scour populations are possible-hence two solutions arise from each seismic intersection. The two solutions from a single seismic intersection will be referred to as a solution-pair. Linear densities are determined by calculating the average number of scours that are detected per line kilometre. For each solution of a solution-pair, an average direction and a corresponding optimum scour density are calculated. The optimum scour density is related to the average scour length per unit area. To use the following equations, one of the seismic lines is arbitrarily dubbed BB', and the other, $\mathrm{AA}^{\prime}$. The scour orientations relative to seismic line $\mathrm{AA}^{\prime}$ (figure 7.9) and the optimum scour densities for each solution-pair are determined in the equations below.

$$
\begin{aligned}
& \alpha_{1}=\tan ^{-1} \frac{\sin \phi}{\rho+\cos \phi} \\
& \rho_{1}=\frac{\rho_{a}}{\sin \alpha_{1}} \\
& \alpha_{2}=\tan ^{-1} \frac{\sin \phi}{\rho-\cos \phi} \\
& \rho_{2}=\frac{\rho_{a}}{\sin \alpha_{2}}
\end{aligned}
$$

where:

$$
p=\frac{p_{b}}{\rho_{a}}
$$

$P_{b}$ is the linear density on line BB'

$$
\rho_{\mathrm{a}} \text { is the linear density on line } \mathrm{AA}^{\prime}
$$


\$ is the acute angle between $\mathrm{BB}^{\prime}$ and $\mathrm{AA}^{\prime}$

$a_{1}$ is the angle between line $\mathrm{AA}^{\prime}$ and the orientation of the first solution (in the direction of the obtuse angle)

$\rho_{1}$ is the optimum scour density of the first solution

$\alpha_{2}$ is the angle between line $\mathrm{AA}^{\prime}$ and the orientation of the second solution (in the direction of the acute angle)

$\rho_{2}$ is the optimum scour density of the second solution

The solution-pairs generated at each of sixteen intersection points in scoured areas are calculated in table $\mathbf{7 . 1}$ and are plotted on a paleobathymetric map of Emerald Basin (figure 7.10). Three solution-pairs on the eastern flank of the basin (in figure 7.10) are expanded in figure 7.11, to illustrate how several solution-pairs in close proximity permit the significant solution to be determined.

Two of the three solution-pairs drawn in the south-western end of the basin (in figure 7.10) were not derived from the intersection of two lines, but rather from the two lines leading away from a turning point in the ship track. The linear densities were calculated over a length of $1.5 \mathrm{~km}$ of seismic lines, not $3 \mathrm{~km}$ as is the other data. The significant solutions of these solution-pairs are oriented ENE to wsw.

Nine solution-pairs are generated on the eastern flank of the basin. In seven of these, the two solutions of each solution-pair are nearly paralle! to E-W trending 
Table 7.1: Seismic intersections and solution-psirs

\begin{tabular}{|c|c|c|c|c|c|c|}
\hline \multirow[t]{2}{*}{ Cruise } & \multirow{2}{*}{$\begin{array}{l}\text { time/day/jr } \\
\text { BB' }^{\prime}\end{array}$} & \multirow{2}{*}{$x^{\text {Cruise }}$} & \multirow{2}{*}{$\begin{array}{l}\mathrm{time}^{\prime} \\
\mathrm{d} \text { day/yr }\end{array}$} & \multirow{2}{*}{$\begin{array}{l}\text { Acute Angle } \\
\Phi \text { (degrees) }\end{array}$} & \multicolumn{2}{|c|}{ Solution-pair } \\
\hline & & & & & $\alpha_{1}$ & $\alpha_{2}$ \\
\hline K'75 & $0120 / 103 / 75$ & × 79-011 & $0715 / 158 / 79$ & 57 & 33 & 19 \\
\hline $86-034$ & $0940 / 315 / 86$ & $\times 79-011$ & $0710 / 158 / 79$ & 68 & 44 & 28 \\
\hline $\mathrm{K} \cdot 75$ & $0110 / 103 / 76$ & x $86-034$ & $0945 / 315 / 86$ & 56 & 28 & 17 \\
\hline $79-011$ & $0528 / 158 / 79$ & $x$ S -24 & $1612 / 239 / 78$ & 75 & 34 & 27 \\
\hline 79-011 & $0515 / 158 / 79$ & x s-24 & $2155 / 238 / 78$ & 80 & 37 & 31 \\
\hline$x \cdot 75$ & $0857 / 103 / 75$ & × 79-011 & $0435 / 158 / 79$ & 75 & 10 & 9 \\
\hline 79-011 & $0410 / 158 / 79$ & $x$ s -24 & $2103 / 238 / 78$ & 86 & 5 & 5 \\
\hline $\mathrm{Br}=73$ & $1712 / 040 / 73$ & $x$ s -24 & $2047 / 238 / 78$ & 87 & 9 & 9 \\
\hline $74-M 18$ & $2250 / 093 / 74$ & x S-24 & $2047 / 238 / 78$ & 78 & 16 & 13 \\
\hline $\mathrm{Br} \cdot 73$ & $1745 / 040 / 73$ & $\times 79-011$ & $1739 / 158 / 79$ & 85 & 24 & 23 \\
\hline $77-005$ & $0620 / 105 / 77$ & $\times 79-011$ & $1747 / 158 / 79$ & 87 & 14 & 14 \\
\hline $9-68$ & $1740 / 041 / 78$ & $\times 79-011$ & $1819 / 158 / 79$ & 59 & 41 & 23 \\
\hline K'75 & $0951 / 109 / 75$ & $x 86-034$ & $0519 / 315 / 88$ & 62 & 41 & 24 \\
\hline K'75 & $0833 / 103 / 75$ & $x$ s-24 & $2110 / 238 / 78$ & 83 & 8 & B \\
\hline $86-034$ & $0408 / 317 / 88$ & x 79-011 & $2218 / 158 / 79$ & 68 & 37 & 25 \\
\hline $86-034$ & $0332 / 317 / 86$ & x $86-034$ & $0330 / 317 / 86^{*}$ & 76 & 42 & 32 \\
\hline $79-011$ & $2359 / 158 / 79$ & x 79-011 & $0001 / 159 / 79^{*}$ & 46 & 25 & 14 \\
\hline
\end{tabular}

Table 7.1. Seismic cruise intersection points, intersection angles, and $\alpha$ angles for solution-pairs generated in Emerald Basin. Huntec data was collected on cruises Q-68 (CFAV Quest), S-24 (CNAV Sackville), 77-005 (CSS Hudson), 79-011 (CSS Hudson), and 86-034 (CSS Hudson). NSRFC data was collected on cruises $\mathrm{Br}$ '73 (M/V Brandal), 74M18 (CNAV Sackville), and K '75 (CNAV Kapuskasing).

- Solution-pair calculated at course change rather than intersection. 


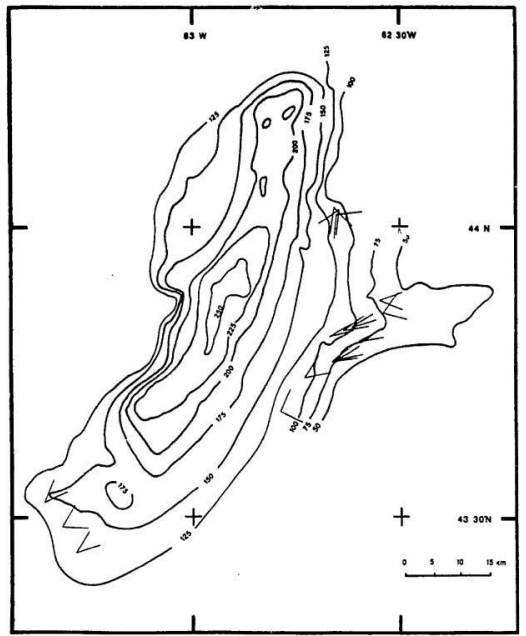

Figure 7.10. Solution-pairs from table 7.1 plotted on a paleobathymetric map of the top of depositional sequence 1 . Contours in $\mathrm{ms}$ twt below a datum plane at $110 \mathrm{~m}$ b.s.l. 


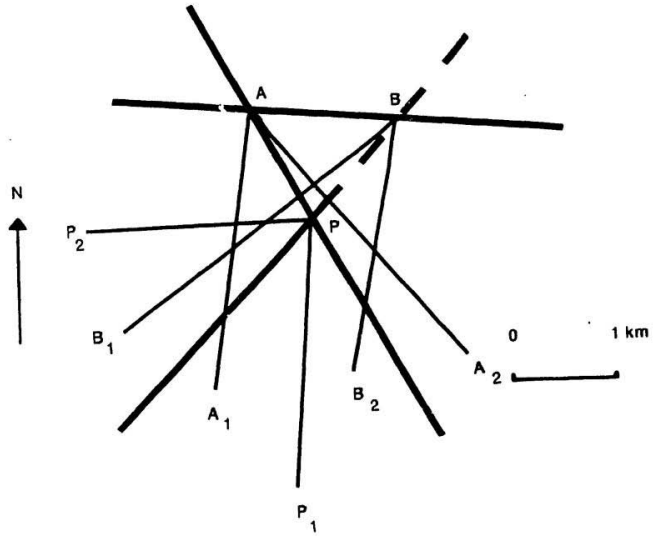

Figure 7.11. A demonstration of how the significant solutions of three closely-spaced solution-pairs can be determit ".. The actual scour orientations mest be parallei to one of $A_{1}$ or $A_{2}$, one of $B_{1}$ or $B_{2}$ and one of $P_{1}$ and $P_{2}$. Only a population of scours oriented $\mathrm{N}-\mathrm{S}$ ean satisfy the requirements of all three solution-pairs. 
seismic lines. The significant solutions of each of these seven solution-pairs is WSW to ENE.

Mapping the significant solutions against paleobathymetry demonstrates that the features are generally oriented parallel to paleobathymetric contours (figure 7.12). Exceptions occur near the mouth of the channel on the eastern fank, and at the southwest flank of the basin (figure 7.12).

Optimum scour densities for the significant solutions show a strong negative correlation with depth (figure 7.13), as was qualitatively demonstrated in figure 7.7. An $\mathrm{F}$ test, which is a statistical test to determine the significance of the relationship between two variables, indicates a $\mathbf{8 9 . 9 \%}$ chance of a significant relationship between depth and scour density.

Meltwater and turbidite channels would be expected to be oriented normal to bathymetric contours, thus eliminating them from consideration as a potential source of the linear scours. Scours oriented parallel to bathymetric contours are probably current-influenced, rather than gravity-influenced. The upper boundary of d.s. 1 is marked by "moats" around some topographical highs (chapter 3.2) and depositional sequence 2 shows evidence of currents (chapter 3.3), implying that currents are strongest during depositional sequence 2. Beçause there was no simultaneous increase in the size or number of scours at this time, they probsbly do not form by the direct action of currents. Ice scouring mechanisms are the most probable cause of these features. Fast ice and multi-year ice scour to a maximum of $47 \mathrm{~m}$ below sea level (Hibler et al., 1972; Lewis, 1077). The paleobathymetric range 


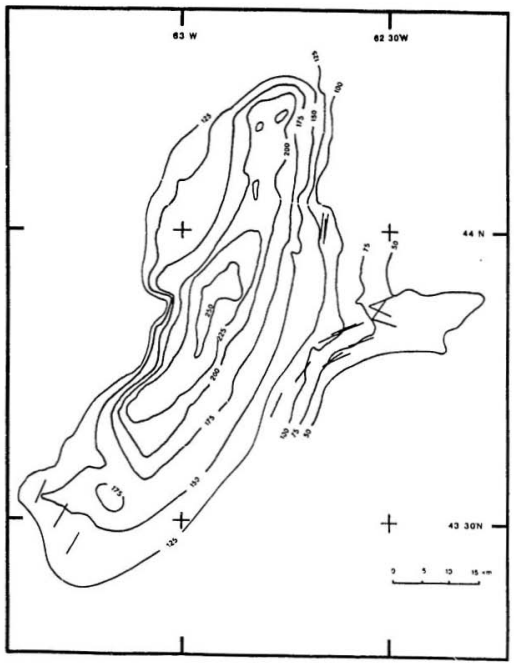

Figure 7.12. Significant solutions of scour orientations plotted on a paleobathymetric: map of the top of depositional sequence 1. Where significant solutions could not be determined, the origibal solution-pairs from table 7.1 are plotted. Contours in mis twt below a datum plane at $110 \mathrm{~m}$ b.s.t. 


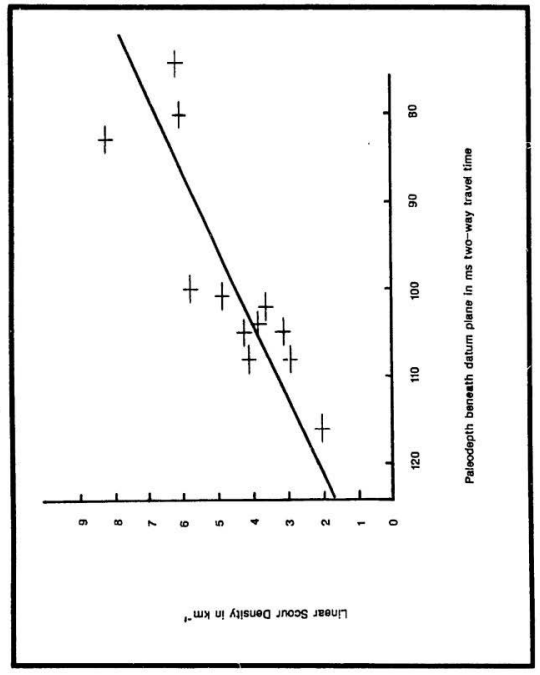

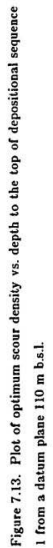


of scours is in excess of $130 \mathrm{~ms}$ twt $(100 \mathrm{~m})$. Thus, fast-ice and multi-year ice are insufficient by themselves to cause all of the scours observed. The paleobathymetric range is too great for the scours to have been caused by a floating ice shelf, as the undersurface of such a shelf becomes smooth rapidly (Paterson, 1981), whereas the paleobathymetric range of scours observed at the top of d.s. 0 , at the top of d.s. 1 , and within d.s. 2 and 3 is large. Ieebergs and ice islands are the most probable mechanism, although some of the scouring may have been due to multi-year ice. King (1876) demonstrates that iceberg scours may be detected on high-resolution seismic records even after burial. Todd et al. (in press) note that icebergs do not show preferential orientation except in the presence of strong translatory currents.

Frequencies of iceberg impact decrease exponentinlly with depth (Barrie, 1980). The paleobathymetric range of the data plotted in figure 7.13 is insufficient to determine whether the relationship between scour depth and scour density is exponential or linear, although there is clearly a decline in scouring with incresing water depth. The optimum scour density decreases by a factor of about three over a paleobathymetric range of $30 \mathrm{~m}$, implying a decrease in the average scour length per unit area. Modern scour densities on Saglek Bank are observed to decrense by a factor of three over a bathymetric range of $30 \mathrm{~m}$ (King and Gillespie, 1986).

Iceberg and ice island movements are controlled by currents, winds, sraflowr morphology, storms, wind and water drag forces, and the Corio'is force (Barrie, 1980; Sodhi and El-Tahan, 1980; Drewry and Cooper, 1981; Weodworth-lyn:s mt al., 1085). Currents and seafloor morphology are dorninant (Todd 르 느., in press), whereas the other forces cause only small-scale chang's in icrberg motions (van der 
Linden, et al., 1976). Because the movement of scouring icebergs is similar to that of free-floating icebergs (Woodworth-Lynas et al., 1985), scours reflect psleocurrent directions (Todd et al., in press). The number of impact marks on the west side of a sill across the eastern channel is larger than that observed on the east side of the sill (figure 7.14) implying a paleocurrent now direction from west to east. This inferred flow direction suggests that icebergs exited the basin via the east channel, drifting through Western Gully to the sea. Although no orientations could be determined for the scours in the southern end of the basin, their numbers imply that there was a conduit for icebergs through the saddle west of Emerald Bank. The intercalation between Emerald Silt and the till in the southern end of the basin (chapter 3.3) implies the presence of a ridge of grounded ice. The presence of iceberg scours on both sides of the ridge further implies that ice was calving on two fronts. The orientations of the scours west of the ridge indicate drift along a southwest-northeast track, thus icebergs were probably calved off the ice margin and drifted to the southwest, before turning to the south and exiting the basin through the saddle west of Emerald Bank. The icebergs east of the ridge calved off the ice margin, drifted along the southeast nank to the northeast, some drifting out the east channel to the sea, the rest drifting northward along the eastern flank (figure 7.15).

\section{4 "Lift-off" moraines}

-Lift-off" moraines are described as subparallel ridges of till that have complex relationships with overlying (Emerald Silt) reflections, which terminate against their edges (King and Fader, 1988). "Lift-off" moraines have been interpreted to be synchronous with the Emerald Silt. (King and Fader, 1986). 


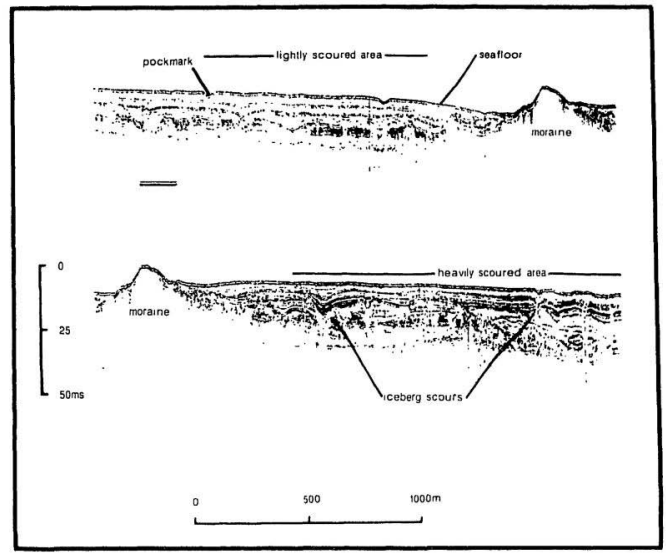

Figure 7.14. SSLFC: V.fin sparket profile from the easern rhanul shesuing

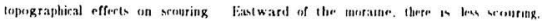

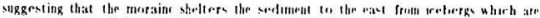

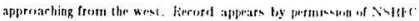




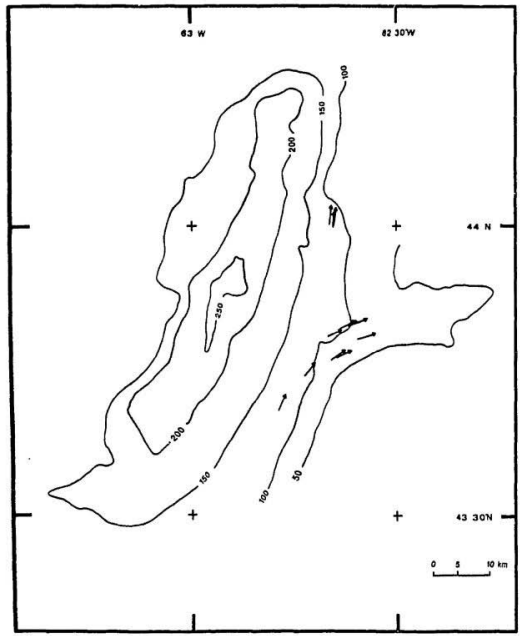

Figure 7.15. Inferred iceberg movement directions from profiles plotted on a paleobathymetric map of the top of depositional sequence 1 . Contours in ms twt below a datum plane at $110 \mathrm{~m}$ b.s.1. 
"Lift-off" moraines in Emerald Basin are usually less than $3 \mathrm{~m}$ high and $80 \mathrm{~m}$ wide, and usually occur in fields (figure 7.16). The average spacing between them ranges from $100 \mathrm{~m}$ to $400 \mathrm{~m}$. The upper boundary of d.s. 0 is the upper limit of most of the moraines, and the internal reflections of d.s. 0 terminate against the edges of the "lift-off" moraines (figure 7.16). Their distribution does not appear to be depthcontrolled (figure 7.17). King and Fader (1986) proposed that "lift-off" moraines form when a grounded marine ice sheet becomes buoyant, depositing till where the ice remains in contact with the seanoor, and depositing stratified material beneath the floating ice. In the NSRFC record (figure 7.18), the reflections of d.s. 0 overlie the "lift-off" moraines. Emerald Silt was not, therefore, deposited simultaneously with the "lift-off" moraines, as King and Fader (1986) have suggested. The "liftoff" morsines also appear to be only about $25 \mathrm{~m}$ wide as opposed to $50-80 \mathrm{~m}$ wide as they do on Huntec records (figure 7.16). The terminating reflections shown in figure 7.16 are probably a result of high ship speed $(>14 \mathrm{~km} / \mathrm{hr})$, the large distance between the fish and the seafloor $(>150 \mathrm{~m})$, and the large vertical exaggeration of the figure $(>30 \mathrm{X})$. NSRFC data is typically collected at low speed $(<6 \mathrm{~km} / \mathrm{hr})$, with a small distance between the towed lish and the seafloor $(<50 \mathrm{~m})$, and with a low vertical exaggeration $(8 \mathrm{X})$.

The attenuation of the reflection events over the "lift-off" moraines (figures 7.16 and 7.18 ) may indicate that their slopes are greates than they appear. Subbottom features with very steep slopes may not be recorded accurately on high resolution seismic records (Van Overeem, 1878). A sharp peak usually generates a hyperbolic reflection. The abundance of backscattered energy from reflections from Scotian Shelf Drift (Maclsaac and Dunsiger, 1977) would generate incoherent 

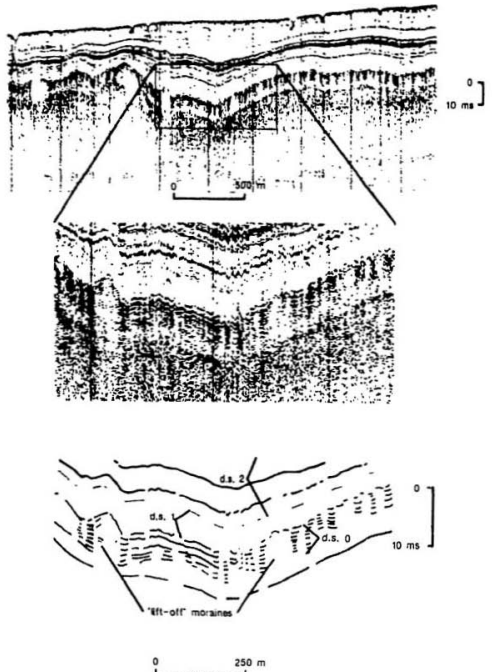

Figure 7.16. Interpreted Huntec DTS profile from the eastern flank. Eimerald Basin. showing internal reflections of depositional sequence 0 terminating againt the flanks of 'lift-off' moraines. 


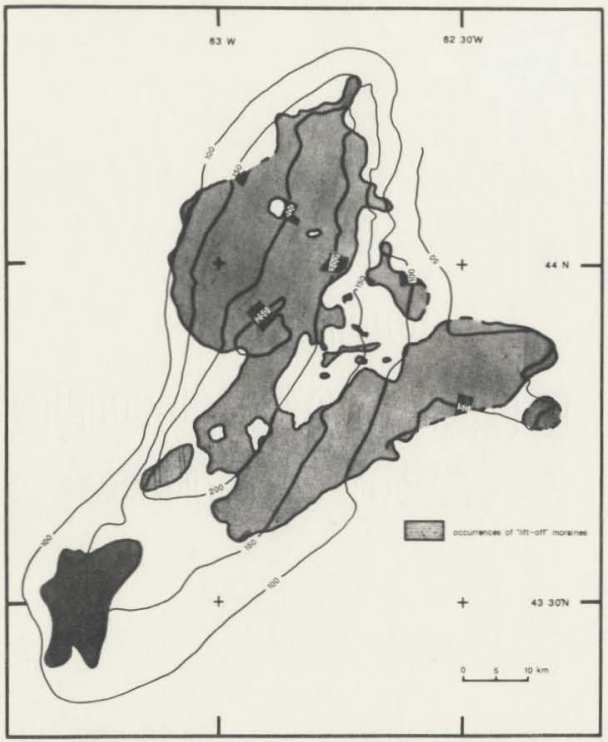

Figure 7.17. Distribution of "lift-off" moraines plotted on a paleobathymetric map of the top of depositional sequence 1. Contours in $\mathrm{ms}$ twt below a datum plane at $110 \mathrm{~m}$ b.s.l. 


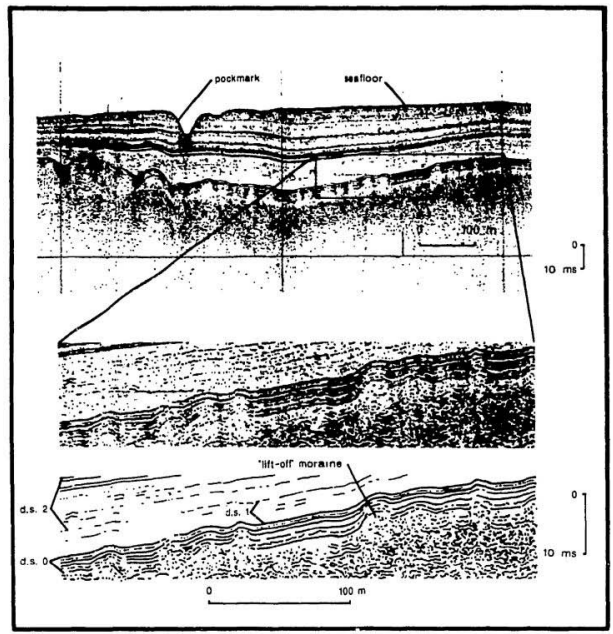

Figure 7.18. Interpreted NSRFC V-fin sparker profile over the same area as ligure $\mathbf{7} .16$, showing that the internal reflections of depositional sequence 0 are draped over top of "lift-off" moraines. 
reflection events benesth such a hyperbolic reflection, resulting in what would appear to be a broad "moraine" (figure 7.18). The apparent form of such a "moraine" would be 3 function of the height of the feature and the distance between it and the seismic source/receiver (figure 7.19). The height and width of the apparent feature can be used to determine the apparent beight of the towed fish above the feature.

$$
\mathrm{Ap}=\frac{\frac{w_{\mathrm{app}}{ }^{2}}{4}-h_{\mathrm{app}}{ }^{2}}{2 \cdot h_{\text {app }}}
$$

where $A p$ is the apparent height of the fish above the moraine

$w_{\text {app }}$ and $h_{\text {app }}$ are the apparent width and height of the moraine

Approximately $50 \%$ of the features sampled generated apparent fish heights (Ap) less than or equal to the actual lish height (Ac) (figure 7.20), indicating that the morphology of $50 \%$ of the sample depends on the height of the towed fish. Such a result indicates that most of the features are not recorded accurately. Only $35 \%$ of the features sampled plot far enough away from the $(A p=A c$ line on figure 7.20) to be considered accurately recorded. These data suggest that while the slopes of some "lift-off" moraines are $1.3^{\circ}$, the slopes of others are $>10^{\circ}$. To accurately record the shapes of the steeply sloping moraines, the fish must be towed closer to the seafloor.

King and Fader's(1086) interpretation of "lift-ofl" moraines were based on Huntec data which showed Enerald Silt rreflections terminating against the nanks of "lift-off" moraines, and in which the apparent width was probably exaggerated. 

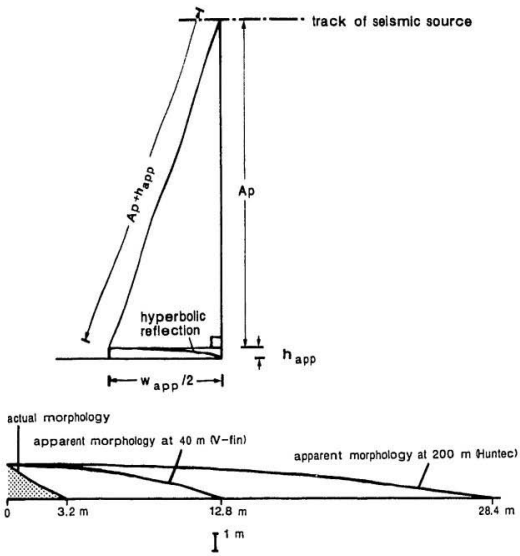

Figure 7.19. Cartoon showing the effects of seabed-receiver distance on the apparent morphology of small till ridges. While the hyperbolic reflections of point reflectors are easily recognizable, byperbolic reflections caused by narrow till ridges may not be so casily recognized, because energy is returned not only from the crest of the ridge, but is also scattered from the side of the ridge, senerating incoheseat reflection evento which apparently "fill" the atea beneatb the byperbolic reflection. The byperbolic reflection intersects the till surface when the beight of the scismic source above the till surface aquals the separation between the source and the srest of the ridge so that $w_{\text {spp }} / 2=\sqrt{2 h_{\text {ipp }} A p+h_{\text {app }}^{2}}$. 


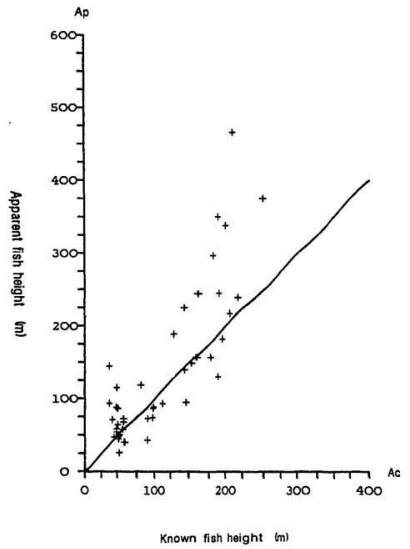

Figure 7.20. Appareat fish height (calculated from morphology of "lift-off" moraines) plotted against knowa fish height. Where apparent fish beight equals real fish height (aloag the diagonal line), the morphology of the "lift-off" moraine is hyperbolic. Most of the points plot near the diagonal line, implying that the morphology of most "lift-off" moraines may not be accurately recorded. In general, as the height of the fish above the seafloor increased, so did the apparent width of "lift-off" muraines of a given height. 
NSRFC data, which suggest that "lift-off" moraines may have steeply dipping flanks and were formed entirely before deposition of Emerald Silt, imply a different origin. The inferred morphology of a typical "lift-off" moraine (up to $3 \mathrm{~m}$ in height, apparently $<20 \mathrm{~m}$ in width) is similar to that of deGeer moraines in central Finland, reported by Zilliacus (1987), and of moraines which form transverse to icefow directions (Prest, 1968). Because they are subparallel linear ridges (King and Fader, 1986; King et al., 1987), their average orientation, and thus ice-flow directions may be estimated using the method described in chapter 7.3. On the basis of the significant solutions, the basin is divided into four areas: the western area, where orientations are N-S, (ii) the northern area, where orientations are NWSE, (iii) the southern area, where orientations are E-W, and (iv) the central area, where significant solutions were not determined (figure 7.21). There is a single solution-pair in the eastern channel, oriented differently from the soiution-pairs in the basin, which probably represents features similar to cross-valley moraines (Andrews and Simpson, 1866). If the orientation of the "lift-off" moraines is normal to ice flow directions, then the data imply at least two lobes of ice flowed into Emerald Basin, one from the north end of the basin, flowing down the centre of the basin, and one from Sambro Bank, probably flowing through LaHave Basin.

\subsection{Till Tongues}

Till tongues are described as wedge-shaped bodies of till, which are acoustically continuous with constructional mounds of basal till, with the thin edge interbedded with Emerald Silt (King and Fader, 1986). They were, therefore, formed simultaneously with the iill mounds. Emerald Silt reflections diverge upon encountering the thin edge, or "feather edge", of the till tongue. Reflections 


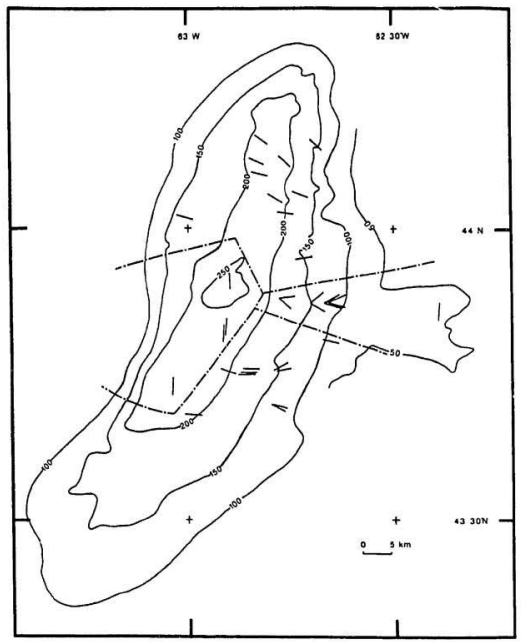

Figure 7.21. Significant solutions for the orientation of "lift-off muraines on a paleobathymetric map of the top of depositional sequence 0 (contours in ms twt below a datum plane $110 \mathrm{~m}$ b.s.l.). On the basis of orientation, the basin is divided into four areas: (i) the northern ares, where moraines are oriented approximately F-W, (ii) the western arca, where they are oriented N-S, (iii) the southern area, whre thry are oriented roughly E-W, and the central ares, where the significant solutions could not be determined. 
seismostratigraphically higher than the till iongue feather edge continue over top of the feature, while those reflections lower than the feather edge of the till tongue continue underneath (King and Fader, 1986). Some reflections gently onlap onto the till tongue's upper surface, implying that the feature is deposited simultaneously with Emerald Silt, though at a much higher rate (King and Fader, 1986). King et 3l. (1987) deseribe such features as linear buoyancy line moraines and include them as a subclass of till tongues. The basal layer of till in the Norwegian Sea is considered to be an agglomeration of stacked till tongues (King et al., 1887). In longitudinal section, a till tongue appears as a characteristic wedge-shaped outline, progressively thinning from root to feather edge (figure 7.22), while in transverse section, it appears as a series of lenticular bodies with no apparent internal structure, pinching out along the same reflector (figure 7.23).

Each till tongue in Emerald Basin is designated a number from 2 to 6 , in order of occurrence, as in King and Fader (1986) and King et al. (1987). A till tongue number refers to the seismostratigraphic level at which the till tongue occurs. Till tongue 2, therefore, refers to all till tongues occurring at the same seismostratigraphic level irrespective of whether it is a single till tongue of regional extent, or a series of small till tongues.

The interfingering relationship between till tongues and Emerald Silt implies that they accrete gradually rather than forming instantaneously. X-radiographs from core 87003-008 show bands of alternating silt and clay within about $1 \mathrm{~m}$ of the inferred horizon corresponding to the feather edge of a till tongue. 


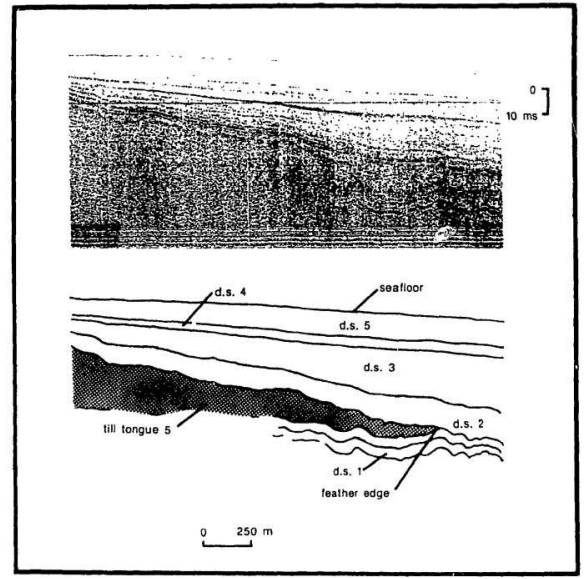

Figure 7.22. Interpreted Hunter DTS profile terim the arothern end of temerald buan. showing a longutudinal sertuin of $\mathbf{a}$ till tringue 

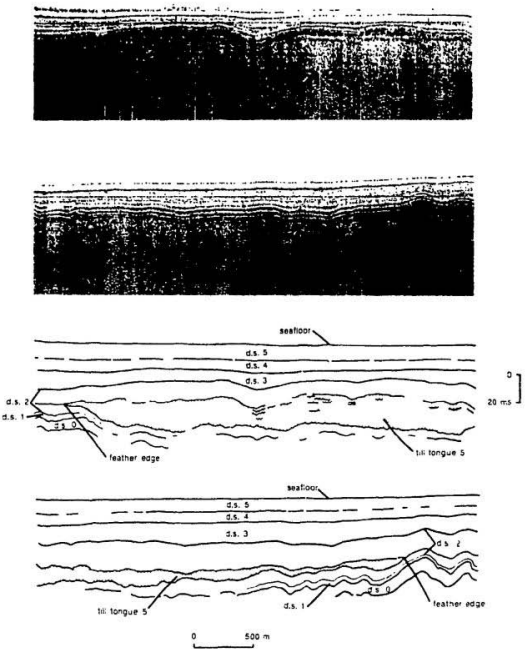

Figure 7.23. Interpreted lluntec DTS profile from the northern end of Emerald Basin. depicting a transverse section of the same till tongue as in figure 7.22 . 
On the basis of geometrical relationships between till tongues and constructional ridges of till, King and $\mathrm{F}$ ader (1988) proposed that till tongues are deposited at the fluctuating buoyancy line of a floating ice shelf. Unstratified diamict is deposited where the ice remains in contact with the seafloor, while stratified sediments are deposited beneath the adjacent floating ice shelf.

Longitudinal and transverse seismic lines were run over till tongue 5. The longitudinal line (figure 7.22) shows a single feature which satisfies the criteria proposed by King and Fader (1986) for the definition of a till tongue. Some overlying reflections gently onlap the till tongue's upper surface, and there is a similar relationship observed between the underlying relections and the lower surface. The transverse line (figure 7.23) shows that the feature has the form of an irregular lenticular body. The limits of the till tongue are apparently defined by small crests, while the main body of the tongue occupies the trough in between. As the underlying Emerald Silt facies reflections do not appear to be disturbed, the trough is probably not caused by the till tongue. The till tongue has, therefore, formed in the trough.

Under the mechanism proposed by King and Fader (1988), till tongues would occur along topographic highs. Till tongues 2,3 , and 5 appear to be occurring in topographic lows, suggesting a different mechanism. The depositional style of till tongues is similar to the irregular style of Syvitski (in press), which often indicates slumping. The acoustic signature of these till tongues is not consistint with material that has been deposited through a water column. The relationship with the adjacent Emerald Silt reflections implies that the features built up by a process 
of gradual accretion, in such a manner as to prevent the development of internal structure. Because they are acoustically continuous with constructional ridges of basal till, they are ice marginal. A till tongue stratigraphy, as in King et al. (1887), can, therefore, be used to estimate the position of the ice margin at stratigraphic intervals where till tongues occur (figures 7.24 to 7.26 ).

Till tongue 2 (figure 7.24) occurs in depositional sequence 0 and is the most extensive till tongue in the basin. It is observed along the northern and eastern flank of the basin. This data implies that grounded ice surrounded the northern half of Emerald Basin during much of depositional sequence 0. Till tongue 3 (figure 7.25) occurs at the top of d.s. 0 , but is only observed in the eastern channel. This data need not mean that there was no grounded ice around the basin at the base of depositional sequence 1 , but rather that conditions were unfavourable to till tongue formation within Emerald Basin. Till tongue 4, which occurs at the top of d.s. 1, is limited to the northern flank of the basin, near the termination of the old Sackville River Channel (figure 7.25). There was ice along at least part of the northern margin of Emerald Basin at the end of depositional sequence 1. Till tongue 5, which occurs within depositional sequence 2 , is also restricted to the northern flank of the basin (figure 7.26). Its occurrence is more widespread than that of till tongue 4. Till tongue 6 , which occurs at the top of d.s. 2 , is restricted to the southern part of the basin (figure 7.26), probably indicating grounded ice in the southern portion of the basin. Iceberg scours occur in the upper part of depositional sequence 2 southwest of this hypothesized ice margin (chapter 7.3). If grounded ice in the south of the basin formed this tongue, then it must have had the form of a slender bridge of ice, grounded where depositional sequences 0,1 , and 2 intercalate with till. 


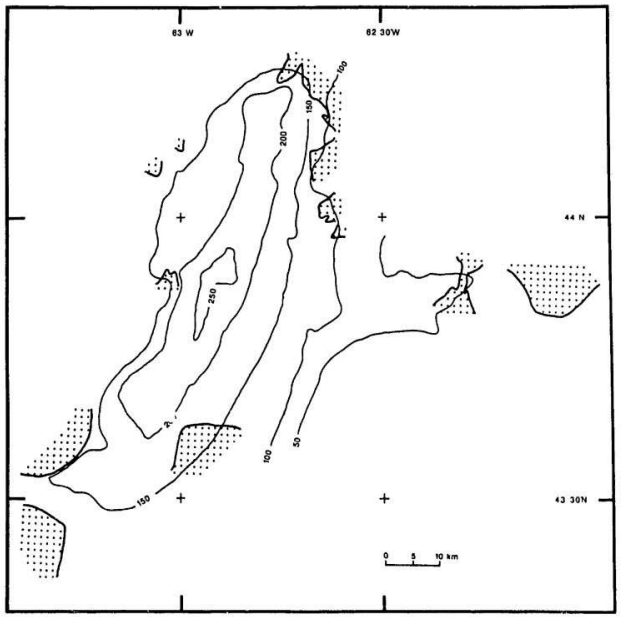

Figure 7.24. Lateral extent of till tongue 2, as mapped from scismic profiles: Paleobathymetric contours are depth to top of depositional sequence 1 in ms twt from a datum plane at $110 \mathrm{~m}$ b.s.l. 


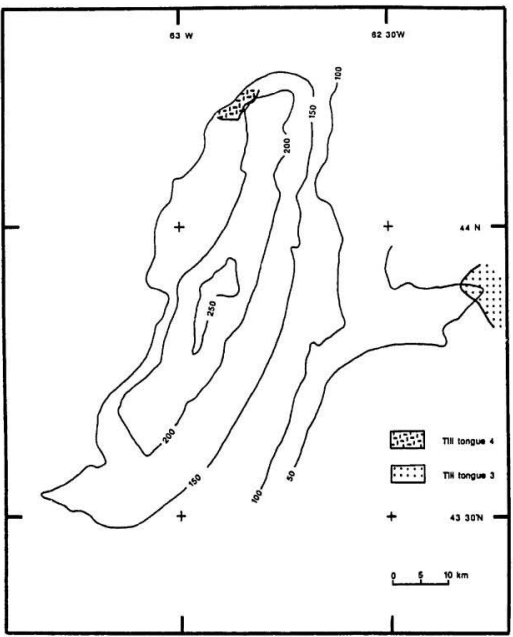

Figure 7.25. Lateral extent of till tongue 3 and 4, as mapped from seismic profiles. Paleobathymetric contours are depth to top of depositional sequence 1 in ms twt from a datum plane at $110 \mathrm{~m}$ b.s.l. 


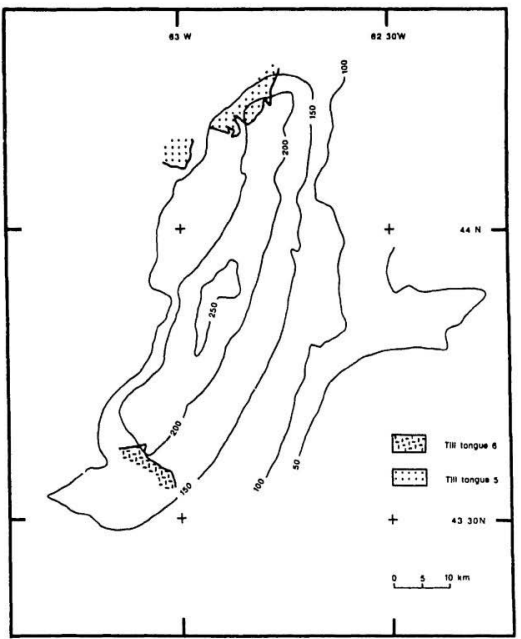

Figure 7.26. Lateral extent of till tongues s and 6, as mapped from seismic profilms. Paleobathymetric contours are depth to top of depositional sequence 1 in ms twt from a datum plane at $110 \mathrm{~m}$ b.s.l. 
Till tongues probably form at an ice margin when the amount of sediment supplied by subglacial meltwater increases over a period of time, possibly due to a widespread melting event behind the grounding line. In grain-size samples from core 006, near the level of till tongue 6, turbidites comprise up to $30 \%$ of the sediment. In the same core, at the level of till tongue 6 , there is a well sorted sand layer which may also be deposited from a turbidity current. In grain-size samples from stratified Emerald Silt taken from core 004, far from any till tongue, turbidites only comprise up to $10 \%$ of the samples, and no well sorted sand bodies are found (chapter 4.3). Sediment-laden meltwater may result in turbidites and slumping at the grounding line, which could be responsible for the acoustic character of till tongues. Till tongues would not, then, be expected to form all around the basin simultaneously, but should form simultaneously along all parts of the ice margin supplied by the same source of meltwater. The fact that a till tongue 3 , at the top of d.s. 0, occurs along the eastern Ilank of Emerald Basin, but not along the northern flank (figure 7.25) aeed not imply that ice was grounded only along the eastern flank, but could imply a sudden influx of meltwater from the direction of western Sable island Bank. Likewise, the restriction of till tongues 4 and 5 to the northern flank would imply an increase in the supply of meltwater from the north, possibly transported along the old Sackville River channel, wbile till tongue 6 (figure 7.26) suggests melting of ice in the southern extreme of Emerald Basin. Till tongue 2, which surrounds the basin, would imply a melting event that affected ice all around Emerald Basin. When till tongue 2 was forming, the ice surrounding Emerald Basia acted in mncert, but when subsequent till tongues formed, different lobes or rises of ice were acting independently. 


\section{Reconstruction of the late Wisconsinan environment in Emerald Basin}

\subsection{Ice flow directions}

The extent of the ground till sheet, combined with the wedge-shaped festures observed in Verrill Canyon (Mosher, 1987), indicates that glacial ice reached as far as the shelf break in the late Wisconsinan. Ice flow directions during the advance of the ice are usually estimated on the basis of the limits of the basal till sheet (eg. Josenhans et al., 1986), taking advantage of the fact that the now direction of a fluid is perpendicular to its margin. As the dates obtained in this thesis (chapter 6) cannot be extended to the base of the till sheet, the age of the ice advance is only speculative. The wedge-shaped feature of Mosher (1987), which may represent the period of maximum ice advance, is estimated to be about $24.5 \mathrm{ka}$. Amos and Knoll (1987) estimate an ice advance on Banquereau at 20-28 ka. The ice probably advanced directly across the basin (figure 8.1).

Ice surges, which are thought to be the most important process acting during the breakup of ice sheets (Denton and Hughes, 1084), are known to cause basal crevasses in ice (Zilliacus, 1987). Zilliacus (1987) proposes that a retreat of the buoyancy line brought on by a sea level rise causes DeGeer moraines to form by the squeezing of wet-based till into the basal crevasses of the ice, which are mainly transverse to ice-nlow directions. Such a mechanism would produce positive topographic features which show no intercalation with the subsequently deposited muds. 


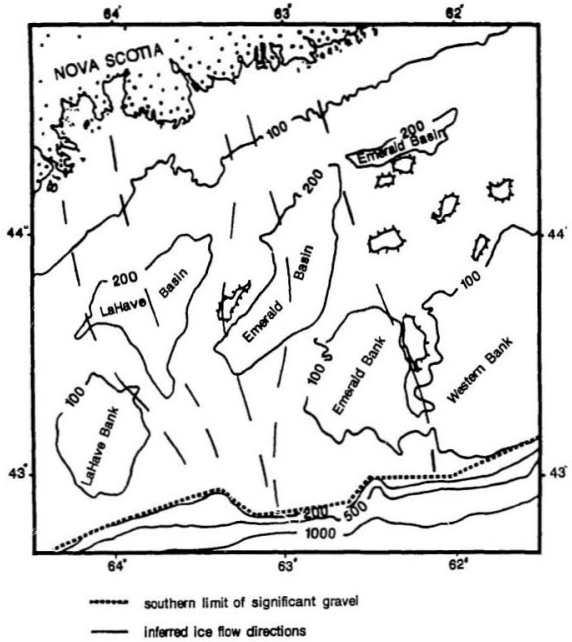

Figure 8.1. Map of the Scotian Shelf showing estimated ice now directions during the advance of a iate Wisconsinan ice sheet. Limit of significant gravel is derived from King and Fader (1986). Ice now directions inferred to be normal to the maximum extent of ice, and to be slightly influeneed by shelf topography. Verrill Canyos is at the shelf edge just east of the figure. 
The ice flow directions during retreat (chapter 7.4) imply that there was an ice rise on Sambro Bank, and ice flowing along the eastern channel, either westward from Sable Island Bank or eastward from Emerald Basin. There are two possibie implications for flow directions in the centre of the basin: i) ice flowed from the northern margin of the basin, through the central trough, and southeastward out of the basin, (figure 8.2) or ii) ice flowed from both the northern and southern margins into the centre of the basin (figure 8.3). While ice is grounded, it nows outwards from spreading centres. If it loses contact with the seafloor at any point, the remaining grounded areas form ice rises, in which ice flow directions are independent of the regional flow directions (Thomas, 1970). Sambro Bank and the other banks on the Scotian Shelf are observed to have erosional terraces on them which are presumed to represent the low stand in sea level. If the banks were exposed, or at least under very shallow water, they could serve as grounding points for glacial ice. For the pattern of ice flow depicted in figure 8.3 , there must have been ice rises on Sambro Bank and Emerald Bank, and ice grounded north of Emerald Basin. The large sediment wedge on the southeast nank of Emerald Basin (chapter 3.3) which thickens towards the southeast implies a large sediment source on Emerald Bank.

Because Quinlan and Beaumont's $(1981 ; 1982)$ model of isostatic rebound implies only minor ice on the Scotian Shelf, the ice advancing to the shelf edge must have been thin. For it to persist for several thousands of years, the outer banks must bave been accumulating areas. This is not unreasonable, considering that the ice would not likely be in contact with the Gulf Stream, there is an inexhaustible supply of moist air, and the thermal gradient at the ice front would probably have formed an intense storm track. 


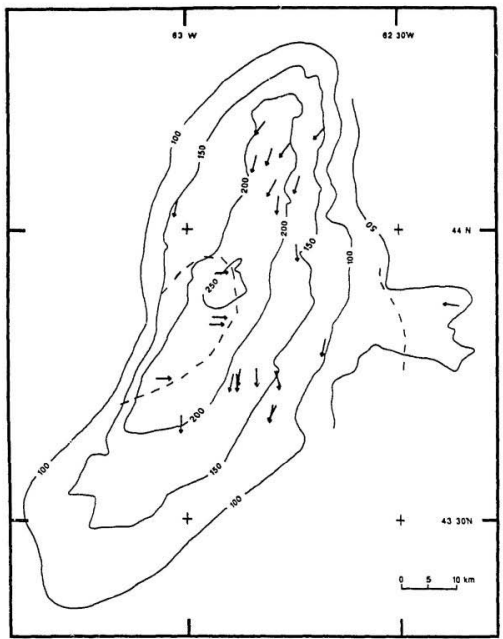

Figure 8.2. Possible ice flow directions during retreat of ice from Emer, determined from the orientation of "lift-off" moraines. This model implies an ice rise grounded on Sambro Bank, ice nlowing westward along the eastern channel, and southwards through the basin. 


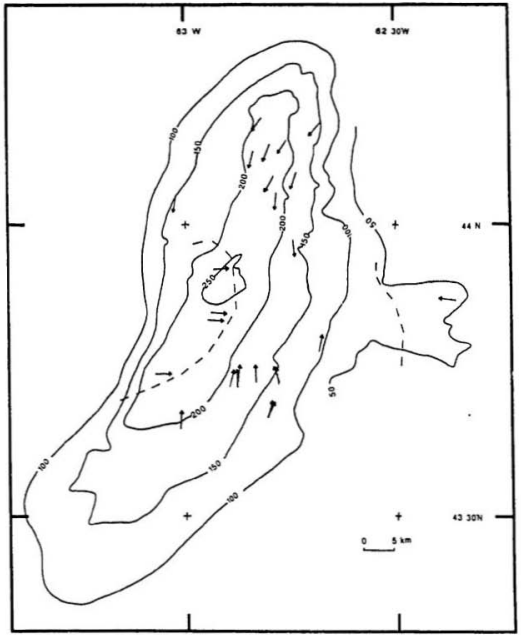

Figure 8.3. Possible ice now directions during retreat of ice from Emerald Basin, determined from the orientation of "lift-off" moraines. This model differs from that of figure 8.2 in that it implies ice flowing northwards into the basin from an ice rise on Emerald Bank. 


\subsection{Lithofacies interpretation}

Lithofacies 5 is a sandy mud, the coarse sand of which is dominated by metamorphic rock fragments (chapter 4.1). As this lithofacies correlates with d.s. $\mathbf{0}$, the rate of sedimentation is inferred to be at least $20 \mathrm{~m} / \mathrm{kyr}$ (chapter 6.3 ). There are no in situ molluses, the numbers of benthonic foraminifers is very low, being about 25 tests/g (Lewis et al., 1088), and there is very little bioturbation, which implies that conditions were unfarourable for marine organisms. Foraminiferal zone F1, which has been interpreted as a warm ice margin fauna (Scott et al., 1984) is related to this lithofacies. These data suggest very high sediment loads and the proximity of melting ice. Such conditions could suggest the calving of ice in and around Emerald Basin, or the existence of an ice shelf.

Lithofacies 4 is a slightly gravelly mud, the coarse sand of which is generally dominated by metamorphic rock fragments, but includes considerable quartz and authigenic goethite. Sedimentation rates are implied to be $10-15 \mathrm{~m} / \mathrm{kyr}$, and grainsize curve dissection suggests that plume sediments dominate, whereas ice rafting contributes $<10 \%$ of the total sediment in the central part of the basin. The benthonic foraminifera present are of assemblage F2, molluses are of assemblage M2, both of which suggest turbid waters with a high sediment load (chapter 5.2). These data suggest a large supply of meltwater and debris, with most of the sediment being supplied by meltwater. Ice rafted debris may be supplied by icebergs calving from a tidewater margin. This lithofacies represents deposition while the ice margin is proximal to the basin.

Lithofacies 3 is a mud, the coarse sand of which is dominated by authigenic 
pyrite and composite metaquartzite grains, with minor amounts of metamorphic rock fragments. Dissection of the grain-size curves suggests that $\mathrm{pl}^{-1}$ me sedimentation dominates in the centre of the basin, with ice rafting and underflows being of less importance. In the southern end of the basin, however, the one sample from this lithofacies suggests that half of the sediment is ice rafted, with suspension rain-out and underflows contributing the rest. Lithofacies 3 is characterised by foraminiferal assemblage $\mathrm{F} 2$, molluscan assemblage $\mathrm{M}$, dinoflagellate assemblage D2, and pollen zones $\mathrm{L}$ and $\mathrm{G}$, implying turbid waters and high sedimentation rates, and glacial to late glacial conditions on land (Mudie, 1980). The increasing diversity of the molluscs suggests a decline in the turbidity of the water. Whereas the coarse sand of lithofacies $\mathbf{4}$ had been dominated by metamorphic rock fragments, with minor quartz and quartzite, the coarse sand of lithofacies 3 contains much quartz and quartzite, but only minor metamorphic rock fragments. The decrease in the sand-sized metamorphic rock fragments cculd be caused by an increase in the transport distance of the sediment, which would cause metamorphic rock fragments to break down into clays and silt-sized qrartz grains, implying either a retreat of the ice front, or melting and sediment supply from more distant areas in the ice sheet. Lithofacies 3 probably represents deposition from meltwater plumes, ice rafting, and turbidites from distal tidewater ice sheets.

Lithofacies 2, a sandy mud, is only observed in core 006, collected near the feather edge of till tongue $B$. In terms of grain-size distribution and coarse sand content, it is similar to lithofacies 5. Dissection of the grain-size curves suggest that ice rafted debris comprises up to $35-70 \%$ of the sediment, with the rest being divided up evenly between underflows and suspension rain-out. Few molluscs are 
present, representing assemblage M2. The importance of ice rafted debris and underflows, plus the low numbers of shells present, and the proximity of a till tongue, suggest that this is an ice marginal facies.

Lithofacies 1 is quite distinctive fiom the other four lithofacies in terms of grain-size distribution and coarse sand composition. It is a sandy silt, the coarse sand of which is dominated by organic debris (ehapter 4.1). Dissection of the grainsize curves suggest that the sediment is dominated by components that plot in the turbidite field (chapter 4.3). As the sedimentation rate is inferred to be on the order of $1 \mathrm{~m} / 2000 \mathrm{y}$, which is $<10 \%$ that of underlying lithofacies, the dominance of organic debris could be a function of lowered sedimentation rates, or increased production. This lithofacies is characterised by foraminiferal assemblage F3 (Vilks and Rashid, 1976; Scott et al., 1984; Lewis et al., 1988), molluscan assemblage M4, dinoflagellate zone D3, and pollen assemblages C and A (Chapter 5.2; Mudie, 1080). Lithofacies 1 probably represents deposition in an ice-free environment. Ice was likely not present on the Scotian Shelf or near the coast. Sediment was supplied from reworking of material on the inner shelf, and later, by reworking of Emerald Silt from within Emerald Basin (Williamson et al., 1984).

The differences in sedimentology between core 004 and core 006 may be explained in terms of the difference in distance from an ice margin. Core 006 was take? very close to till tongue 6 , at a point $<2 \mathrm{~km}$ from the estimated position of the ice margin, whereas core 004 was taken $>20 \mathrm{~km}$ from the estimated position of the ice margin of the eastern Mank. The formation of till tongue 6 implies an ice margin in the southern end of Emerald Basin at approximately $15 \mathrm{ka}$. It is known 
that the rate of deposition of ice rafted debris decreases rapidly away from an ice margin (Drewry and Cooper, 1981). The importance of underflows will also decrease rapidly from an ice margin. Thus, a core taken near an ice margin will have greater relative amounts of ice rafted debris and debris flow sediments than will a distal core.

\subsection{Depositional sequence interpretation}

\section{Depositional sequence 0}

The base of d.s. 0 represents the onset of deposition of sediment through a water column, and thus, the retreat of grounded ice from Emerald Basin. There are two possible mechanisms by which the ice may retreat from the centre of the basin:

i) lift-off, to form a floating ice shelf or ii) retreat of a tidewater margin (Powell, 1084).

Depositional sequence 0 is characterised by lithofacies 5 , which is interpreted to have been deposited from either a noating ice shelf, or from a rapidly calving marine ice sheet. Because no buried iceberg scours occur in d.s. $\mathbf{0}$ (chapter 7.3), it is unlikely that there were many icebergs in the basin. Depositional sequence 0 is suggested to have been deposited beneath a loating ice shelf of short duration because (i) it is draped, covering most topographic features uniformly, unlike overlying depositional sequences (ii) it does not show influence of storm-wave resuspension, implying either a lack of storms, or that the seafloor was somehow protected from their influence (iii) till tongue 2 is observed to extend around the basin, with the exception of the southeastern flank (iv) there are no buried iceberg scours (v) there are no in situ molluses (vi) the numbers of benthic foraminifers is 
very low-8 tests/g in core 000 (Vilks and Rashid, 1076), and about 25 tests/g in core 004 (Miller, pers. comm.) (vii) there is very little bioturbation. (viii) $50 \%$ of all buried scours in Emerald Basin occur on the top of d.s 0.

The data suggest a short-lived floating ice shelf over Emerald Basin, which suddenly calved at the top of d.s. 0 , with a buoyancy line as depicted in figure 8.4 at about $17.5 \mathrm{ka}$. Ice would bave remained grounded on the banks, forming ice rises. Because $\underline{P}$ arctica valves are found in d.s. 1 , the duration of the ice shelf is probably no more than about 100 years. The sedimentation rate is implied to be at least $1 \mathrm{~m} / 50 \mathrm{yr}$, which, although bigh, is less than the rates measured in Muir Inlet, Alaska (Mackiewicz et al., 1984), and in fjords in Spitzbergen (Elverhoi, 1984). This amount of sediment would be supplied to the ice margin by subglacial or englacial meltwater (Gustavson and Boothroyd, 1987), rather than by basal meltout (King and Fader, 1986). The isopach map of d.s. 0 (figure 3.17) suggests a sediment source to the southeast of Emerald Basin, as well as one to the north.

\section{Depositional sequence 1}

The upper boundary of d.s. 0 is marked by a large number of iceberg scours. This reflection, therefore, represents the sudden calving of the ice shelf responsible for d.s. 0. No further scouring is observed until the top of d.s. 1. Non-deposition is observed around positive topographic features with very steep sides, probably due to a sudden increase in current strength. The effects of currents do not persist, and the upper half of d.s. 1 is only slightly affected by currents. When an ice shelf calves, current strength may increase due to the reduction in friction at the icewater interface. The subsequent decrease in current strength could be due to the beginning of ses level rise at about $17 \mathrm{ka}$ (Dillon and Oldale, 1978), which increases 


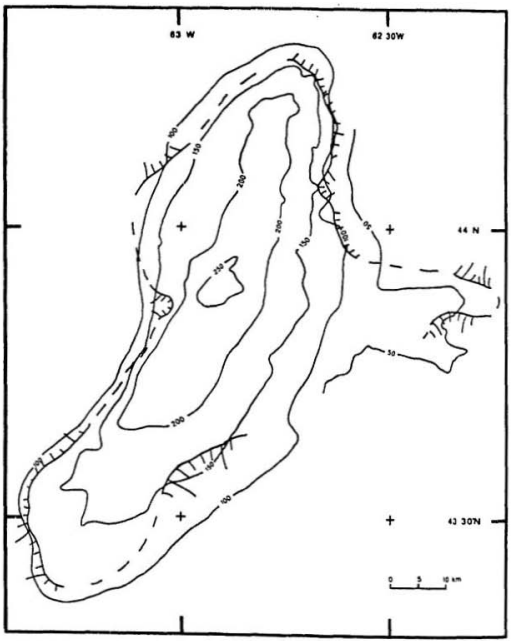

Figure 8.4. Estimated position of ice margin ca. $17.5 \mathrm{ka}$ on the basis of the lateral extent of till tongue 2 . 
the crose-sectionsl area through which the currents must now, decreasing their velocity. Till tongue 3 , which occurs at the upper boundary of d.s. 1, indicates grounded ice on the eastern flank of the basin, and an increase in meltwater from the direction of western Sable Island Bank (chapter 7.5). The location of the buoyancy line is not known elsewhere.

The acoustic architecture of d.s. 1 is consistent with a unit deposited by rain out of either sediment plumes or ice rafted debris, influenced by storm-wave reworking of sediments (Barrie and Piper, 1982). Yet the non-deposition observed at the base of the unit around topographical features indicates that currents are also a factor.

The sediment in d.s. 1 is usually of lithofacies 4 , representing ice proximal deposition, either beneath an ice shelf or near a tidewater margin. The presence of noating ice is reflected in the numbers of dropstones and the occasional sandy and gravelly layers thought to represent material dropped from overturning icebergs (chapter 4.4). Laminations observed in core 004 at this horizon represent alternation between layers dominated by rain-out of suspended sediment, and ice rafted debris (chapter 4.3).

The upper boundary of d.s. 1 is also heavily scoured. The scours on this horizon account for $30 \%$ of the total scours observed in Emerald Basin. There is non-deposition around positive topographic features, but on a larger scale than at the base of d.s. 1. This may be explained by either the formation of a new ice shelf during deposition of d.s. 1, slowing down currents and preventing further scouring 
until the ice shelf calves again, releasing more icebergs and increasing current velocities, or by raising ses level, causing rapid retrest and calving of ice, opening a conduit from the eastern channel through the Western Gully to the sea, accelerating currents near the mouth of the eastern channel, where most of the non-deposition at the top of d.s. 1 is found. The second explanation is to be preferred, because there is no decline in abundance of molluses near the top of d.s. 1, as would be expected if an ice shelf re-established itself, and current effects were concentrated around the mouth of the eastern channel.

The series of events during depositional sequence 1 is thought to have been as follows: (i) at the top of d.s. 0 , the floating ice shelf calves, creating numerous icebergs in the basin, which move counter-clockwise, with the current (ii) till tongue 3 forms in the eastern channel, possibly signalling the retreat of ice west of the channel (iii) sea level begins to rise ca. $17 \mathrm{ka}$, causing rapid calving of ice on the Manks of the basin, initiating a new phase of scouring (iv) ice completely clears the eastern channel, opening a conduit between Emerald Basin and the sea through the eastern channel and the Western Gully.

\section{Depositional sequence 2}

Depositional sequence 2 exhibits the conformable cover style of deposition (chapter 3.3), with slight infilling of the basin deeps, suggesting slight influence by storm waves or by turbidity currents. The isopach map suggests a major source of sediment to the southeast (probably from Emerald Bank), another source to the north (retreating ice margin), and another to the east (possibly from the unnamed banks east of Emerald Basin, or Western Bank). Depositional sequence 2 is characterised primarily by acoustic facies 4, but acoustic facies 5 is present in two 
areas (chapter 3.1). This acoustic facies corresponds to Emerald Silt facies C of King and Fader (1986), which they interpreted as representing deposition beneath a floating ice shelf near the buoyancy line. The limits of a.f. 5 are marked by a number of iceberg scours, which could represent the calving margin of small ice shelves, one grounded on Emerald Bank, and the other on the unnamed banks on the northeastern flank of Emerald Basin. Alternatively, acoustic facies 5 may represent an ice-keel turbate.

The feather edge of till tongue 4 corresponds to the upper boundary of d.s. 2 , confirming the presence of grounded ice on the northern flank of the basin. Till tongue 5 also occurs during d.s. 2, and signifies the presence of ice across the northern flank of Emerald Basin at about $16.7 \mathrm{ka}$. As till tongue 5 is the last till tongue across the northern flank, it may be related to the retreat of the grounding line north of Emerald Basin. The presence of till tongue $b$ on the upper reflection event of d.s. 2, as well as the intercalation of till and Emerald Silt in the southern end of the basin probably indicates a rapid advance of ice into the southern end of Emerald Basin from either Emerald Bank or Sambro Bank.

The derived orientations of iceberg scours in d.s. 2 indicate current directions are counter-clockwise, which is the expected direction of storm-driven currents in the basin. Iceberg scours southwest of the "ncck" of ice between Sambro and Emerald Banks are oriented towards the southwest. These icebergs either flow into LaHave Basin or out to sea between Emerald Bank and LaHave Bank.

The sediment corresponding to d.s. 2 is lithofacies 4 , an ice proximal deposit, 
in the middle of the basin, and lithofacies 2 , an ice marginal facies, in the southern end of the basin. There are a few of the gravelly sandy mud horizons in cores which are thought to represent material dumped from overturning icebergs (chapter 4.4).

Thus, during d.s. 2, flosting ice did not entirely cover Emerald Basin, although there were numerous icebergs. The ice margin around the basin is interpreted to have been a tidewater margin. Emerald Basin was surrounded by ice

rises on the banks, but there were open conduits to the sea through the eastern channel, leading out to the Western Gully, and through the trough between Emerald and LaHave Banks.

\section{Depositional sequence 3}

On the basis of the dates from chapter 6 , a period of non-deposition at the upper boundary of d.s. 2 is inferred. Its duration and timing are variable. Depositional sequence 3 terminates erosionally on all flanks except the southeastern nank. The erosion is most pronounced around the mouth of the eastern channel, where current velocities are expected to be higher (chapter 3.3). The thickening of d.s. 3 towards Emerald Bank suggests the presence of ice on the bank. The thickening of d.s. 3 in the northern part of the basin indicates the ice margin north of the basin continued to provide sediment. The depositional style of this depositional sequence is controlled by storm-wave reworking of sediments, or by a mis sure of underflows and suspension fall-out (chapter 3.3).

The sediment is generally lithofacies 3 , which is interpreted to be an ice-distal glacimarine sediment. The declining number of dropstones upsection, and the 
increased ponding of the unit (especially in the basin deeps) indicates that the relative importance of ice rafted debris and suspension rain-out decreases upcore, while that of sediment gravity nows increases. The changing importance of depositional mechanisms is difficult to verily, as d.s. 3 cannot be sampled where it is ponded in the basin deeps because the overlying depositional sequences are too thick. Molluscan faunal diversity increases upsection, which is consistent with either a decrease in the sediment load of the water, or an increase in either temperature or salinity. However, because this sequence is characterised by assemblages F2 and D1 (chapter 5.2), meltwater continues to be an influence. The pollen in this sequence represents a terrestrial glacial assemblage (Mudie, 1080).

The differences in the effects of currents on this sequener and on lower sequences possibly reflects a rising in sea level. The non-depositional hiatus inferred between depositional sequences 2 and 3 may have been caused by currents. Depositional sequence 3 was deposited symmetrically about high points, especially in the basin deeps. Thus current strength was weak from $15 \mathrm{ka}$ to about $14 \mathrm{ka}$, but became suddenly much stronger after $14 \mathrm{ka}$, when the widespread erosion at the base of d.s. 4 occurred.

This sequence was deposited under the influence of meltwater, although some distance from the ice margin, signifying a retreat of ice northward. Ice was apparently still active on Emerald Bank.

\section{Depositional sequence 4}

Depositional sequence 4 mainly oceurs in the basin deeps, but is thickly deposited on the southeastern flank of Emerald Basin. The lower boundary of d.s. 4 
is erosional around the flanks of Emerald Basin, except for the north flank. Buried pockmarks are abundant, possibly indicating alternating periods of high and low sedimentation rates, as pockmarks form shen sedimentation rates are low, and are buried during times of rapid sedimentation (chapter 7.2).

Depositional sequence 4 is characterised by lithofacies 3 , which is interpreted to represent ice-distal glacimarine sedimentation. The pollen record probably indicates the ice retreating from the coastline, as refuges are large enough to grow trees. Ice is still close enough to the coast to provide substantial meltwater to the basin.

\section{Depositional sequence 5}

Depositional sequence 5 exhibits the onlapping basin-fill style of deposition, implying that storm-wave reworking, and possibly turbidites, are the major processes affecting sedimentation (Barrie and Piper, 1982). The isopach map suggests that the thickness variability of d.s. 5 can be explained in terms of basin topography, with no active sources to the south or east of Emerald Basin.

At the base of d.s. 5, the molluscan assemblage is $\mathrm{M} 3$, similar to the 'mature Portlandia' assemblage of Syvitski et al. (1988). The importance of $\underline{E}$. excavatum in the foraminiferal assemblage decreases dramatically, corresponding to an increase in $\underline{\mathrm{C}}$. reniforme and I. helenae. Faunal diversity increases upwards from there, as the foraminiferal assemblage changes from F2 to F3. At the same time, the number of dinonlagellate eysts increases sharply, and the assemblage changes from D1 to D2. Assemblage D2 has been interpreted as indicating surface water temperatures as warm as those presently in Emerald Basin (Mudie, 1980). The terrestrial pollen 
assemblage changes to zone $A$, interpreted as the transition from early postglacial Noral assemblages to the early Holocene assemblage (Mudie, 1980). A second change in biofacies occurs one-third of the way through the sequence. The molluscan assemblage changes to M4, while the dinoflagellates, and pollen change to present day assemblages. Variable numbers of $\underline{\mathrm{E}}$ excavatum tests are found in assemblage F1, but these have been found to have been reworked (Williamson et al, 1984), implying that reworked Pleistocene sediments are an important component of d.s. 5 .

Depositional sequence 5 represents the Holocene deposition in Emerald Basin. There is a decline in the sedimentation rate, to a maximum of $1.5 \mathrm{~m} / \mathrm{kyr}$, which is reflected by both the thickness of the unit and the number and size of pockmarks at the surface. The pollen record indicates the disappearance of ice from Nova Scotia, and the marine microfossil record indicates the disappearance of meltwater influences. The erosion occurring at the present day seafloor was probably initiated about the time that numbers of reworked E. excavatum tests increase in foraminiferal assemblage FI ( $\sim 2 \mathrm{ka})$. This last period of erosion may have been triggered by a changing circulation pattern brought upon by sea level rise rather than by a fall of sea level, as there is no evidence of sea level fall on Sable Island Bank at this time (Scott et al., 1988).

\subsection{Deglaciation and post-glacial history}

Deglaciation of Emerald Basin was likely induced by surging of grounded ice within the basin. This surging led to tho formation of crevasses in the ice (Zilliacus, 1987), which increased the rate of melti,; Basal crevasses squeezed material of the basal till sheet to form "lift-off" moraines oriented normal to ice flow directions 
when the ice sheet lifted off the seafloor at about $17.5 \mathrm{ka}$. An ice shelf of very limited duration $(<100$ y) covered Emerald Basin, during which d.s. 0 was deposited (figure 8.5). The ice shelf calved, producing numerous icebergs which heavily scoured the upper surface of d.s. 0. As eustatic sea level began to rise around $17 \mathrm{ka}$ (Dillon and Oldale, 1978), the ice margins around Emerald Basin retreated, calving rapidly, releasing another group of icebergs which heavily scoured the upper surface of d.s. 1 (figure 8.6). Molluses established themselves near the base of d.s. 1, and increased in numbers and diversity through d.s. 2 and 3 . The dominant process of sedimentation through d.s. 1 and 2 was rain-out from sediment plumes, and sources were primarily from ice grounded north of Emerald Basin, from ice grounded on either western Sable Island Bank or on the unnamed banks east of the basin, and from ice grounded on Emerald Bank. Ice on the outer banks was maintained by bigh rates of winter accumulation, which offset the high rates of summer ablation.

Ice retreated from the northern flank by about $16 \mathrm{ka}$, and by $15 \mathrm{ka}$, sedimentation through most of the basin was an ice-distal facies, with sediment plumes dominating the nanks of the basin, turbidites contributing to sedimentation in the basin deeps, and an ice marginal facies in the southern end of Emerald Basin related to a surge of ice fiom Emerald Bank (figure 8.7).

A rapid increase in current strength abnut $14 \mathrm{ka}$ led to a widespread erosive event of $<200$ yr duration (table 6.3 ). Ses level was rising, and this increase in current strength may have been due to an improvement in circulation resulting from the disappearance of ice in the southern end of Emerald Basin, opening the 


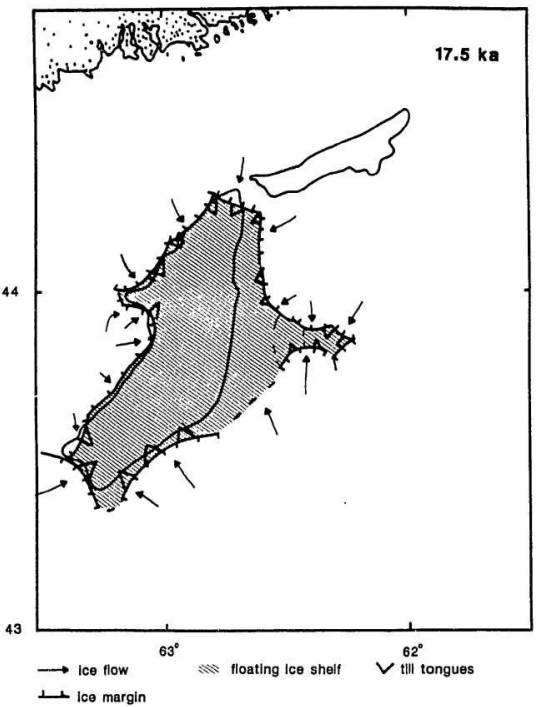

Figure 8.5. Cartoon showing goneralized position of grounded ice margin, till tongues, and ice flow directions around Emerald Basin at $17.5 \mathrm{ka}$. Ice southeast of Emerald Basin is grounded on Emerald Bank. Ice east of the basin is grounded on the small banks north and east of the basin. Ice west of the basin is grounded on Sambro Bank. The basin is defined in this figure and in the next three figures by the $200 \mathrm{~m}$ contour. 


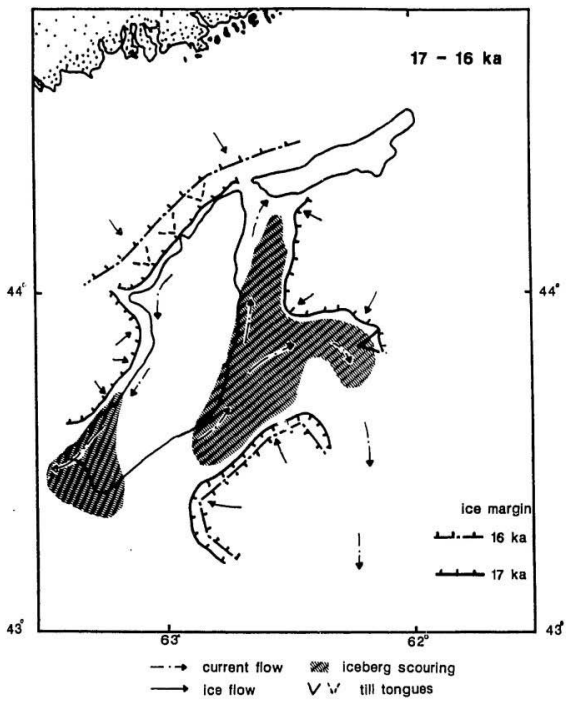

Figure 8.6. Cartoon showing generalized ice now directions, ice margin positions at $17 \mathrm{ka}$ and $16 \mathrm{ka}$, areas of iceberg scour, and directions of current nlow. Ice southeast of Emerald Basin was grounded on Euaerald Bank. Ice west of the basin was grounded on Sambro Bank. By $16 \mathrm{ka}$, ice was grounded only on Emerald Bank and to the north of the basin. 


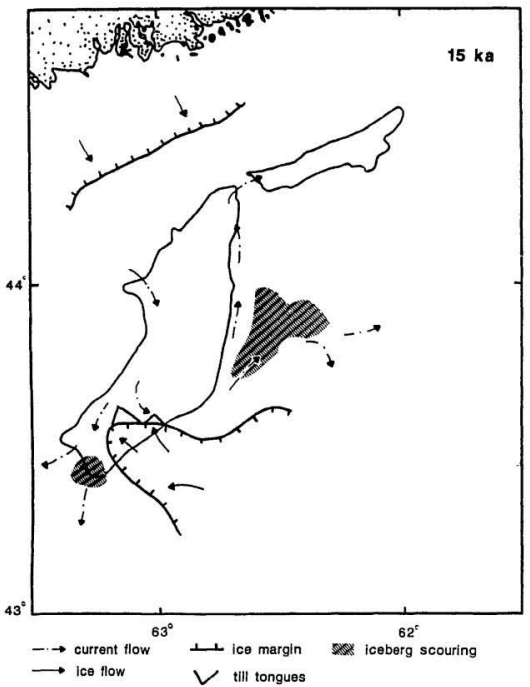

Figure 8,7. Cartoon showing generalized ice and current flow directions, and ice margin positions at $15 \mathrm{ka}$. Ice on Emerald Bank has surged into Emerald Basin, forming till tongue 6 , and probably hastening the subsequent disintegration of the ice rise on the bank. Ice north of the basin has retreatcd from the margin of the basin. 
conduit between Emerald and LaHsve Banks. Meltwater plumes supplied sediment to Emerald Basin throughout d.s. 4, but the sedimentation rate was much lower because the ice margin was distant (figure 8.8). Meltwater supply decreased dramatically at about $12.5 \mathrm{ka}$, whereupon d.s. 5 was deposited. Sediment rates slowed to $<1 \mathrm{~m} / \mathrm{kyr}$. Rising sea level caused reworking of inner shelf sediments, which were the dominant source of material in d.s. 5 . Starting at $\sim 2 \mathrm{ka}$, erosion at the seafloor began again, which apparently has continued to the present. 


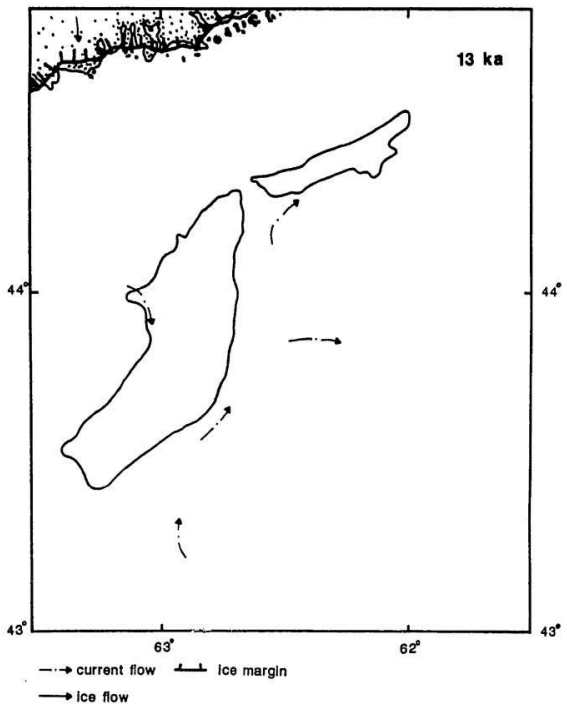

Figure 8.8. Cartoon showing the generalized position of the ice margin, ice flow directions, and current flow directions at $13 \mathrm{ka}$. The ice sheet has retreated to at least the constline and the ice rise on Emerald Bank bas disintegrated. 


\section{Conclusions}

\subsection{Summary}

Seven acoustic facies are recognized in high-resolution seismic records from Emerald Basin. Acoustic facies 1 is correlated to Paleozoic bedrock. Acoustic facies 2 is correlated to Tertiary bedrock. Acoustic facies 3 is correlated to Scotian Shelf Drift, and records the advance of glacial ice across Emerald Basin. Acoustic facies 4 correlates to acoustically stratified Emerald Silt. Acoustic facies 5 correlates to acoustically unstratified Emerald Silt. Acoustic facies 6 correlates to LaHave Clay. Acoustic facies 7 is diffused gas in the sediment.

Six acoustic depositional sequences are recognized in acoustic facies 4 and 6 , which record the retreat of the Late Wisconsinan ice sheet from the central Scotian Shelf. Depositional sequence 0 , the lowermost depositional sequence, i a draped sequence which is interpreted to have been deposited in a matter of decades beneath a floating ice shelf of very short duration. Depositional sequence 1 represents rapid deposition in front of a rapidly retreating ice margin, while icebergs scoured the basin flanks. Depositional sequence 2 represents rapid deposition from rain-out processes with current modification near the eastern channel and thickening in the centre of the basin due either to storm wave reworking or turbidites. Depositional sequence 3 represents deposition from distal ice margins. There is an erosional event of great extent atop d.s. 3, after which depositional sequence 4, which represents slow sedimentation from distal ice sheets, is deposited. Depositional sequence 5 represents deposition f:om inner shelf sediments reworked by rising sea level, hemipelagic processas, and, in the centre of the basin, deposition from early Holocene and late Pleistocene sediments reworked from the flanks of the basin. 
Like King and Fader (1986), the author argues that the Emerald Silt and LaHave Clay in Emerald Basin record the retreat of glacial ice from the Scotian Shelf, but that this deglaciation occurred from $18 \mathrm{ka}$ to $13 \mathrm{ka}$ instead of from $50 \mathrm{ka}$ to $15 \mathrm{ka}$.

Emerald Basin was most recently glaciated about $26 \mathrm{ka}$ by an ice sheet that reached the edge of the continental shelf. Deglaciation was probably caused by a glacial surge within Emerald Basin, causing rapid wasting of the ice, leading to liftoff of the ice in the basin deeps. The squeezing of till into basal crevasses caused the formation of "lift-off" moraines, over which depositional sequence 0 is draped. Depositional sequence $\mathbf{0}$ was deposited beneath a short-lived ice shelf, with sedimentation rates $>20 \mathrm{~m} / \mathrm{ka}$, and dominated by rain-out of sediment from subglacial meltwater plumes. Meltout from basal ice constitutes $10-30 \%$ of the sediment. Variability in the relative importance of ice rafted sediment is likely caused by the episodic nature of the meltwater plumes rather than by changes in the rates of basal melting.

The ice shelf calved about $17.4 \mathrm{ka}$, producing large numbers of icebergs, which heavily scoured the upper boundary of d.s. 0, leaving an ice rise on Emerald Bank. Rising sea level probably initiated rapid retreat of the ice margins accompanied by increased calving at the upper boundary of d.s. 1, at $17 \mathrm{ka}$. The ice margin east of Emerald Basin retreated by $17 \mathrm{ka}$, while north of the basin, the retreat was about $16.7 \mathrm{ka}$. The ice rise on Emerald Bank continued to supply sediment to the southeastern flank of Emerald Basin until $13 \mathrm{ka}$. Deposition from meltwater plumes dominates sedimentation until $13 \mathrm{ka}$, whereupon there is no further indication of ice 
on the continental shelf. Holocene deposition is dominated by hemipelagic processes and sediment reworked by rising sea level, and, in the centre of the basin, early Holocene and late Pleistocene sediments reworked from the basin flanks.

\subsection{Suggestions for future research}

Further research is required to resolve the problem of the morphology of the "lift-off" moraines, by towing seismic gear as close to the seafloor as possible, or by running the same line repeatedly at different depths. In particular, the Huntec DTS should be used at greater depths and lower survey speeds. Even in water depths $>250 \mathrm{~m}$, the tow depth of the Huntec rarely exceeded $00 \mathrm{~m}$.

More research is required to resolve the problem of till tongue formation. It is possible to core till tongue 6, at the southern end of Emerald Basin, and perhaps long cores could be collected so that continuous geotechnical, sedimentological and paleontological profiles through the till tongue can be constructed.

More detailed grain-size curve dissections would be possible if samples were obtained and analyzed on the Sedigraph.

A study of the pore water chemistry may help determine the relationships between occurrences of authigenic pyrite, goethite, "black" bioturbation, and "white" bioturbation. 


\section{References}

Acosta, J., 1984. Occurrence of acoustic masking in sediments of the continental shelf of Spain: Ria de Muros (NW) and Gulf of Cadiz (SW). Marine Geology $\underline{58}$, 427-434.

Amos, C. L., and Knoll, R. G., 1987. The Quaternary sediments of Banquereau, Scotian Shelf. Geological Society of America Bulletin 99, 244-260.

Andrews, J. T., and Smithson, B. B., 1066. Till fabrics of the cross-valley moraines of North-central Baffin Island, Northwest Territories, Canada. Geological Society of America Bulletin 77, 271-290.

Bagnold, R. A., 1937. The size-grading of sand by wind. Proceedings of the Royal Society of London A $163,250-264$.

Bagnold, R. A., and Barndorff-Nielsen, O., 1980. The pattern of natural size distributions. Sedimentology $\underline{27}, 189-207$.

Barrie, C. Q., and Piper, D. J. W., 1982. Late Quaternary marine geology of Makkovik Bay, Labrador. Geological Survey of Canada, paper 81-17, 37p.

Barrie, J. V., 1980. Iceberg-seabed interaction (North Labrador Sea). Annals of Glaciology 1, 71-76.

Belknap, D. F., Shipp, R. C., and Kelley, J. T., 1986. Depositional setting and Quaternary stratigraphy of the Sheepscot estuary, Maine: A preliminary report. Geographie physique et Quaternaire 10, 55-60.

Belknap, D. F., Shipp, R. C., Kelley, J. T., and Schnitker, D., in press. Depositional sequence modelling of late Quaternary geologic history: Sheepscot Bay, west-central Maine cosst. In: C. T. Jackson Memorial Volume, Maine Geological Survey Bulletin.

Bernard, F. R., 1979. Bivalve mollusks of the western Beaufort Sea. Contributions in Science, Natural History Museum of Los Angeles County, no. $313,80 \mathrm{p}$.

Berner, R. A., 1970. Sedimentary pyrite formation. American Journal of Science $\underline{268}, 1-23$.

Bidgood, D. E. T., 1974. A deep-towed sea bottom profiling system. In: Oceans

74: IEEE International Conference on Enginecring in the Occan Environment, Halifax, Nova Scotia, Aug. 21-23, 1974: v, 2, 96-107. 
Boulton, G. S., Chroston, P. N., and Jarvis, J., 1981. A marine seismic study of late Quaternary sedimentation and inferred glacier fuctuations slong western Inverness-shire, Scotland. Boreas $\underline{10}, 39-51$.

Boyd, R., Scott, D. B., and Douma, M., 1988. Glacial tunnel valleys and Quaternary history of the outet Scotian shelf. Nature $\underline{333}, 61-64$.

Bridge, J. S., 1981. Hydraulic interpretation of grain-size distributions using a physical model for bedload transport. Journal of Sedimentary Petrology $\underline{51}$, no. 4, 1109-1124.

Buzas, M. A., 1972. Patterns of species diversity and their explanation. Taxon 21, 275-286.

Christiansen, C., Blaesid, P., and Dalsgaard, K., 1084. Re-interpreting 'segmented' grain-size curves. Geological Magazine 121, 47-51.

Clark, J. A., 1976. Greenland's rapid postglacial emergence: a result of ice-water gravitation attraction. Geology 4, 310-312.

Coulter Electronics, Inc., 1978. Coulter counter model TA-II Operator's manual. Coulter Electronics, Hialeah, Florida. 89p.

Cowan, E. A., Powell, R. D., and Smith, N. D., 1988. Rainstorm-induced event sedimentation at the tidewater front of a temperate glacier. Geology $\underline{16}$, no. 5 , 400-412.

Denton, G. H., and Hughes, T. J., 1084. The Last Great lee Sheets. Wiley, New York. $484 \mathrm{p}$.

Dillon, W. P., and Oldale, R. N., 1978. Late Quaternary sea level curve: Reinterpretation based on glaciotectonic influence. Geology $\underline{\mathbf{B}}$, 58-60.

Domack, E. W., 1984. Rhythmically bedded glaciomarine sediments on Whidbey Island, Washington. Journal of Sedimentary Petrology $\underline{54}, 582-602$.

Drewry, D. J., and Cooper, A. P. R., 1981. Processes and models of Antarctic glaciomarine sedimentation. Annals of Glaciology $2,117-122$.

Dyke, A. S., 1979. Radiocarbon-dated Holocene emergence of Somerset Island, central Canadian Arctic. In Current Research, Part B, Geological Survey of Canada Paper 70-1B, 307-318. 
Edwerds, M. B., 1078. Glacial Environments. In: Sedimentary Environments and Facies, H. G. Reading (ed.). Elsevier, New York, 418-438.

Elverhoi, A., 1984. Glacigenic and associated marine sediments in the Weddel Sea, fjords of Spitzbergen, and the Barents Sea: a review. Marine Geology 57 , 53-88.

Fenchel, T., and Blackburn, T. H., 1979. Bacteria and Mineral Cycling. Academic Press, London. 225 p.

Fillon, R. H., Hardy, I. A., Wagner, F. J. E., Andrews, J. T., and Josenhans, H. W., 1981. Labrador shelf: shell and total organic matter- ${ }^{14} \mathrm{C}$ date discrepancies. In Current Research, Part B, Geological Survey of Canada, Paper 81-1B, 105-111.

Flint, R. F., 1971. Glacial and Quaternary Geology. John Wiley and Sons, New York. 892 p.

Folk, R. L., 1054. The distinution between grain size and mineral composition in sedimentary-rock nomenelature. Journsl of Geology $\underline{62}, \mathbf{3 4 4 - 3 5 9}$.

Folk, R. L., 1980. Petrology of Sedimentary Rocks. Hemphill Publishing Company, Austin. 184p.

Folk, R. L., and Ward, W. C., 1957. Brazos River Bar: A study in the significance of grain size parameters. Journal of Sedimentary Petrology 27, 3-28.

Fulton, R. J., Karrow, P. F., LaSalle, P., and Grant, D. R. Summary of Quaternary stratigraphy and history, Eastern Canada. In Quaternary Stratigraphy of Canada-A Canadian Contribution to IGCP Project 24. R. J. Fulton (ed.). Geological Survey of Canada, Paper 84-10, 193-210.

Gilbert, R., 1982. Contemporary sedimentary environments on Baffin Island, N. W. T., Canada: Glaciomarine processes in fjords of eastern Cumberland Peninsula. Arctic and Alpine Research 14, 1-12.

Gipp, M. R., and Piper, D. J. W., 1989. Chronology of Late Wisconsinan glaciation, Emerald Basin, Scotian Shelf. Canadian Journal of Earth Sciences 26, no. 2, 333-335.

Goudet, G., 1965. Les fonctions de Bessel et leurs applications en Physics, 2e Edition. Masson et $\mathrm{C}^{\text {ie }}$, Paris. 80p. 
Grant, D. R., 1977. Glacial style and ice limits, the Quaternary stratigraphic record, and changes of land and ocean level in the Atlantic provinces, Canads. Geographie physique et Quaternaire 31, 247-260.

Grant, D. R., and King, L. H., 1084. A stratigraphic framework for the Quaternary history of the Atlantic Provinces. In Quaternary Stratigraphy of Canada-A Canadian Contribution to IGCP Project 24. R. J. Fulton (ed.). Geological Survey of Canada, Paper 84-10, 173-191.

Gustavson, T. C., and Boothroyd, J. C., 1987. A depositional modei for outwash, sediment sources, and hydrologic characteristics, Malaspina Glacier, Alaskn: A modern analog of the southeastern margin of the Laurentide Ice Sheet. Geological Society of America Bulletin $\underline{99}$, 187-200.

Hald, A., 1952. Statistical Theory with Engineering Applications. John Wiley and Sons, Inc., New York. $783 \mathrm{p}$.

Harbison, R. N., 1969. Possible morainal deposits in the Gulf of Maine. Maritime Sediments $\underline{5}, 19-21$.

Harding, J. P., 1949. The use of probability paper for the graphical analysis of polymodal frequency distributions. Journal of the Marine Biological Association of the United Kingdom 28, 141-153.

Hibler, W. D., Weeks, W. F., and Mock, S. J., 1972. Statistical aspects of sea-ice ridge distributions. University of Washington f.iDJEX Bulletin 12, 117-162.

Hovland, M., Judd, A. G., and King, L. H., 1884. Characteristic features of pockmarks on the North Sea Floor and Scotian Shelf. Sedimentology $\underline{31}$, 471-480.

Hutchins, R. W., McKeown, D. L., and King, L. H., 1076. A deep tow high resolution seismic system for continental shelf mapping. Geoscience Canada $\underline{3}$, 95-100.

Inman, D. L., 1952. Measures for describing the size distribution of sediments. Journal of Sedimentary Petrology 22, 125-145.

Ives, J. D., 1978. The maximum extent of the Laurentide ice sheets along the east coast of North America during the last glaciation. Arctic 31, 24-53.

Josenhans, H. W., King, L. H., and Fader, G. B., 1978. A sidescan sonar mosaic of pockmarks on the Scotian Shelf. Canadian Journal of Earth Sciences 15, 331-840. 
Josenhans, H. W., Zevenhuizen, J., and Klassen, R. A., 1988. The Quaternary geology of the Labrador Shelf. Canadian Journal of Earth Sciences 23, 1180-1123.

Keen, M. J., and Piper, D. J. W., 1978. Kelp, methane, and an impenetrable reflector in a temperate bay. Canadian Journal of Earth Sciences $\underline{13}, 312-318$.

Kelley, J. T., and Kelley, A. R., (eds.), 1986. Coastal processes and Quaternary stratigraphy northern and central coastal Maine. Society of Economic Paleontologists and Mineralugists Eastern Section field trip guidebook. Dept. Geological Sciences, University of Maine, Orono. $116 \mathrm{p}$.

King, E. L., and Gillespie, R. T., 1986. Regional iceberg scour distribution and variability on the eastern Cansdian continental shelf. In: Lewis, C. F. M., D. R. Parrot, P. G. Simpkin, and J. T. Buckley (eds.) Ice Scour and Seabed Engineering. Environmental Studies Revolving Funds Report no. 048, Ottawa. pp. 172-181.

King, L. H., 1968. Submarine end moraines and associated deposits on the Scotian Shelf. Geological Society of America Bulletin 80, 83-86.

King, L. H., 1970. Surficial geology of the Halifax-Sable Island map area. Marine Sciences Branch Paper 1. Department of Energy, Mines, and Resources, Ottawa. $16 \mathrm{p}$.

King, L. H., 1976. Relict iceberg furrows on the Lal"entian Channel and western Grand Banks. Canadian Journal of Earth Sciences 13, 1082-1092.

King, L. H., and Fader, G. B., 1986. Wisconsin glaciation of the Atlantic continental sheif of southeast Canada. Geological Survey of Canada, Bulletin 363, 72p.

King, L. H., and MacLean, B., 1870. Pockmarks on the Scotian Shelf. Geological Society of America Bulletin 81 , 3141-3148.

King, L. H., and MacLean, B., 1076. Geology of the Scotian Shelf and adjacent areas. Geological Survey of Canada, Paper 74-31, 31p.

King, L. H., MacLean, B., Bartlett, G. A., Jeletzky, J. A., and Hopkins, W. S., 1970. Cretaceous strata on the Scotian Shelf. Canadian Journal of Farth Sciences $\underline{7}, 145-155$.

King, L. H., Rokoengen, K., and Gunleiksrud, T., 1987. Quaternary seismostratigraphy of the Mid Norwegian Shelf, $65^{\circ}-\underline{-87^{\circ} 30^{\prime}} \underline{N}-\underline{\Lambda}$ till tongue gtratigraphy. IKU publication no. 114, 58p. 
Kontopoulos, N., and Piper, D. J. W., 1982. Storm-graded sand at $200 \mathrm{~m}$ water depth. Geo-marine letters 2 , 77-81.

Lewis, C. F. M., 1977. Estimation of the frequency and magnitude of drift-ice groundings from ice scour tracks in the Canadian Beaufort Sea. Proceedings of the Fourth International Conference on Port and Ocean Engincering under Arctic Conditions, St. Johns, Newfoundland, Canada, 12 p.

Lewis, C. F. M., Anderson, T. W., and Miller, A. A. L., 1988. Lake, ocean, and climate response to meltwater discharge, Great Lakes and Western Atlantic Ocean. Programs and Abstracts of the tenth biennial meeting, American Quaternary Association, 81.

MacIsaac, R. R., and Dunsiger, A. D., 1977. Ocean sediment properties using acoustic sensing. Proceedings of the Fourth International Conference on Port and Ocean Engineering under Arctic Conditions, St. Johns, Newfoundland, Canada. $13 p$.

Mackiewicz, N. E., Powell, R. D., Carlson, P. R., and Molnia, B. F., 1984. Interlaminated ice-proximal glacimarine sediments in Muir Inlet, Alaska. Marine Geology $\underline{57}, 113-147$.

Manchester, K., 1988. C. S. S. Hudson Cruise report 87003. Atlantic Geoscience Centre unpub. internal report.

MeKay, A. G., and McKay, P. M., 1982. Compressional-wave velocity measurement in seabed materials by use of equipment deployed near, but above the bottom. Journal of the Acoustical Society of America 71 (4), 871-878.

McKeown, D. L., 1975. Report of cruise no. 75-007. Bedford Institute of Oceanography, unpublished report.

Milliman, J. D., and Emery, K.O., 1968. Sea levels during the past 35000 years. Science $\underline{162}, 1121-1123$.

Mitchum, R. M., Jr., Vail, P. R., and Thompson, S. III, 1977. Seismic Stratigraphy and global changes of sea level, part 2: The depositional sequence as a basic unit for stratigraphic analysis. In Payton, C. E. (ed.) Seismic Stratigraphy-Applications to Hydrocarbon Exploration. American Association of Petroleum Geologists Memoir 26, Tulsa, Oklahoma, 53-62.

Moore, R. C. (editor), 1060. Treatise on Invertebrate Paleontology, Part N: Mollusca 6 Bivalvia. University of Kansas Printing Service, Lawrence, Kansas. 489p. 
Mosher, D. C., 1987. Latn Quatsrnary sedimentology and sediment instability of a small area on the Scotion Slope. Unpub. M.Sc. thesis, Memorial University of Newfoundland, 247 p.

Mudie, P., 1980. Palynology of later Quaternary marine sediments, eastern Canada. unpub. Ph.D. thesis, Dalhousie University, Halifax, Nova Scolia; 464p.

Mudie, P. J., Piper, D. J. W., Rideout, K., Robertson, K. R., Schafer, C. T., Vilks, G., and Hardy, I., 1984. Standard methods for collecting, describing and sampling Quaternary sediments at the Atlantic Geoscience Centre. Geological Survey of Canada Open File \#1044.

Nambudiri, E. M. V., Teller, J. T., and Last, W. M., 1880. Pre-Quaternary microfossils-a guide to errors in radiocarbon dating. Geology $\underline{8}, 123-128$.

Nelson, C. H., Johnson, K. R., and Barber, J. H., Jr., 1987. Gray whale and walrus feeding excavation on the Bering Shelf, Alaska. Journal of Sedimentary Petrology 57, 419-430.

Olhovich, V. A., 1964. The causes of noise in seismic reflection and refraction work. Geophysics 29, 1015-1030.

Orange, A. S., Leonard, J. E., Sieck, H. C., and Walters, B. G., 1974. Harbour subbottom evaluation using high resolution seismic techniques. In: Oceans '74: IEEE International Conference on Engineering in the Occan Environment, Halifax, Nova Scotia, Aug. 21-23, 1974, v.2, 01-85.

Ovenshine, A. T., 1970. Observations of iceberg rafting in Glacier Bay, Alaska, and the identification of ancient ice-rafted deposits. Geological Society of America Bulletin 81, 801-894.

Parrot, D. R., Dodds, D. J., King, L. H., and Simpkin, P. G., 1980. Measurement and evaluation of the acoustic reflectivity of the sea floor. Canadian Journal of Earth Sciences 17, 722-737.

Passega, R., 1057. Texture as characteristic of clastic deposition. Amcrican Association of Petroleum Geologists Bulletin 41, 1952-1984.

Paterson, W. S. B., 1081. The Physics of Glaciers. 2nd ed. Pergamon Press, Oxford. 380p.

Piper, D. J. W., Letson, J. R. J., Delure, A. M., and Barrie, C. Q., 1983. Sediment accumulation in low sedimentation, wave dominated, glaciated inlets. Sedimentary Geology $\underline{36}$, 105-215. 
Pojeta, J. Jr., 1987. Class Scaphopoda. In Fossil Invertebrates. eds. R S. Boardman, A. H. Cheetham, and A. J. Rowell. Blackwell Scientific Publications, Oxford. 713p.

Powell, R. D., 1084. Glacimarine processes and inductive lithofacies modelling of ice shelf and tidewater glacier sediments based on Quaternary examples. Marine Geology 57, 1-52.

Prest, V. K., 1068. Nomenclature of moraines and ice-flow features as applied to the glacial map of Canada. Geological Survey of Canada Paper 67-57. 32p.

Prest, V. K., 1984. The Late Wisconsinan glacier complex. In: Quaternary stratigraphy of Canada-A Canadian contribution to IGCP Project 24. ed. R. J. Fulton. Geological Survey of Canada Paper 84-10.

Prest, V. K., and Grant, D. R., 1969. Retreat of the last ice sheet from the Maritime provinces--Gulf of St. Lawrence region. Geological Society of Canada Paper 60-33. 15p.

Quinlan, G., and Beaumont, C., 1981. A comparison of observed and theoretical postglacial relative sea level in Atlantic Canada. Canadian Journal of Earth Sciences $\underline{18}, 1146-1163$.

Quinlan, G., and Beaumont, C., 1982. The deglaciation of Atlantic Canada as reconstructed from the postglacial relative sea-level record. Canadian Journal of Earth Sciences 10, 2232-2246.

Rissik, H., 1941. Probability graph paper and its engineering applications. The Engineer, London 172, 276-278 and 296-298.

Robin, G. de Q., 1975. Formation, flow, and disintegration of ice shelves. Journal of Glaciology 24, no. 90, 259-271.

Ross, D. A., and Reidel, W. R., 1967. Comparison of upper parts of some piston cores with simultaneously collected open barrel cores. Deep Sea Research 14. 285-294.

Schiebe, F. R., Welch, N. H., and Cooper, L. R., 1883. Measurement of fine silt and clay size distributions. Transactions of the ASAE, $\underline{2}, 491-494,498$.

Schnitker, D., 1074. Postglacial emergence of the Gulf of Maine. Geological Society of America Bulletin $\underline{85}$, 491-494. 
Schnitker, D., 1976. Late glacial to Recent paleoceanography of the Gulf of Maine. In: 1st International Symposium on Continental Margin Benthonic Foraminifera, Part B: Paleoecology and Biostratigraphy. Maritime Sediments special publication no. $1,385-302$.

Schubel, J. R., and Schiemer, E. W., 1973. The cause of the acoustically impenetrable, or turbid, character of Chesnpeake Bay sediments. Marine Geophysical Researches 2 , 61-71.

Scott and Medioli, 1880. Post-glacial emergence curves in the Maritimes determined from marine sediments in raised basins. Canadian Coastnl Conference, 1980, Burlington, Ontario, Procedings, 428-446.

Scott, D. B., Mudie, P. J., Vilks, G., and Younger, D. C., 188-4. Latest Pleistocene-Holocene paleoceanographic trents on the continental margin of eastern Canada: foraminiferal, dinoflagellate and pollen evidence. Mnrine Micropaleontology 9 , no. 3, 181-218.

Scott, D. B., Boyd, R., Douma, M., Medioli, F. S., Yuill, S., Leavitt, E., and Lewis, C. F. M., 1988. Holocene relative sea-level changes and Quaternary glacial events on a continental shelf edge: Sable Island Bank. In: Late Quntornary Sia level Correlations and Applications: Walter S. Newman Memorial Volume. Eds. Scott, D. B., Pirazzoli, P. A., and Honig, C. A. Kluwere Academic P'ublishers, The Netherlands. NATO ASI series C; Mathematical and P'hysical Siciences 225iB, 105-120.

Sheriff, R. E., 1977. Limitations on resolution of seismic reflections and geolugical detail derivable from them. In Payton, C. E. (ed.) Srismic Stratigraphy.Applications to Hydrocarbon Exploration. American Associntion of P'etroleum Geologists Memoir 26, Tulsa, Oklahoma, 3-14.

Shiki, T., and Yamazaki, T., 1085. A lamina-by-lamina analysis of grain-size distribution in fine-grained turbidites. Sedimentary Geology 1ㅡ, 201-220.

Sodhi, D. S., and El-Tahan, M., 1880. Prediction of an iceberg drift trajectory during a storm. Annals of Glaciology 1, 77-82.

Spencer, D W., 1983. The interpretation of grain-size distribution curves of clastic sediments. Journal of Sedimentary Petrology $\underline{33}, 180-100$.

Spjeldnaes, N., 1978. Ecology of selected late and post-glacial marine launns in the Oslo fjord ares. Geologisks Forningens i Stockholm Forhandlingar $\underline{100}$. 189-202. 
Stow, D. A. V., and Aksu, A. E., 1978. Disturbances in soft sediments due to piston coring. Marine Geology 28, 135-144.

Swift, D. J. P., Schubel, J. R., and Sheldon, R. W., 1972. Size analysis of finegrained suspended sediments: a review. Journal of Sedimentary Petrology $\underline{42}$, 122-134.

Syyitski, J. P. M., in press. On the deposition of sediment within glacierinfluenced fjords: oceanographic controls. Marine Geology, in press.

Syvitski, J. P. M., Farrow, G. E., Atkinson, R. J. A., Moore, P. G., and Andrews, J. T., in press. Baffin Island fjord macrobenthos: Bottom communities and environmental significance. Arctic, in press.

Telford, W M., Geldart, L. P., Sheriff, R. E., and Keys, D. A., 1976. Applied Geophysics. Cambridge University Press, Cambridge, 860p.

Thomas, R. H., 1979. The dynamics of marine ice sheets. Journal of Glaciology 24, no. $90,167-177$.

Thomsen, E., and Vorren, T. O., 1984. Pyritization of tubes and burrows from late Pleistocene continental shelf sediments off North Norway. Sedimentology $\underline{31}$. 481-482.

Todd B. J., Lewis, C. F. M., and Ryall, P. J. C., in press. Comparison of trends of iceberg scour marks to iceberg trajectories and evidence of paleocurrent trends on Saglek Bank, northern Labrador Shelf. Canadian Journal of Earth Sciences, in press.

Vail, P. R., and Mitchum, R. M. Jr., 1977. Seismic stratigraphy and global changes of sea level, part 1: overview. In Seismic stratigraphy--Applications to Hydrocarbon Exploration. Ed. Payton, C. E. American Association of Petroleum Geologists Memoir 26, Tulsa, Oklahoma, 51-57.

Vail, P. R., Todd, R. G., and Sangree, J. B., 1977. Seismic stratigraphy and global changes of sea level, part 5: Chronostratigraphic significance of zeismic reflections. In: Seismic stratigraphy-Applications to Hydrocarbon Exploration. Ed. Payton, C. E. American Association of Petroleum Geologists Memoir 26, Tulsa, Oklahoma, 00-116.

van der Linden, W. J., Fillon, R. H., and Monahan, D., 1978. Hamilton Bank, Labrador margin: Origin and evolution of a glaciated shelf. Geological Survey of Canada Paper 75-40, 31p. 
van Overeem, A. J. A., 1978. Shallow-penetration, high-resolution subbottom profiling. Marine Geotechnology $\underline{3}, 61-84$.

van Weering, T., Jansen, J. H. F., and Eisma, D., 1973. Acoustic reflection profiles of the Norwegian Channel between Oslo and Bergen. Netherlands Journal of Sea Research 6, 2:11-263.

Vilks, G., and Rashid, M. A., 1075. Foraminifern and organic geochemistry if two sediment cores from a pockmarked basin of the Scetinn Shelf. Cienlogieal Society of Canada Paper 75- IC, 5-6.

Vilks, G. V., and Rashid, M. A., 1976. Postglacial palor-ocenatography of Emerald Basin, Sentian Shelf. C'anadian Journal of Earth Sirieners 136. 12563-1245

Visher, G. S., 1968. Grain size distributions and depemitional proresses. Journal of Sedimentary Petrology $39,107+1108$.

Wagner, F. J. C, 1077. Recent molluse distributien patterns nond paleobathymetry, southeastern Beaufort Sen. C'analian Journal of Earth Sirtucens 14, 2013-2028.

Wagner, F. J. E., 188.4. Illustrated catalogur of the molluses (Ciastroproda ant Bivalvia in the Atlantic Geoscience ('entre index colloction). (Geological Sinving of Canada, 76p.

Walcott, R. l., 1970. Isostatic response to loading of the crust in Canada Canadian Journal of Earth Sciences $\underset{7}{7}, \mathbf{7 1 6 - 7 2 7}$.

Walcott, R. I., 1972. Past sea levels, eustasy, and duformation of the Einth Quaternary Research 2, 1-14.

Williamson, M. A., Keen, C. E., and Mudir, P. J., 1984. Foraminifernl distribution on the continental margin off Neva Sestig. Marine Micropaleontology $\underline{9}$, no. 3,212239.

Woodworth-Lynas, C. M. T., Simms, A., and Rendell, C: M., 1945. Ireberk grounding and scouring on the Labrador continental ahelf. Cinld lirgionn Sicience and Technology $\underline{10}, 16.3-186$.

Zilliacus, H., 1987. De Geer moraines in Finland and the nnnunl moraine problem. Fennia 165: 2, 147-234. 


\section{Determining the average orientation of a subsurface population of linear features}

Given two seismic lines $\mathrm{AA}^{\prime}$ and $\mathrm{BB}^{\prime}$ (figure I.1), separated by a known acute angle $\phi$, from which linear density values of $\rho_{a}$ and $\rho_{b}$ bave been respectively determined, there are two possible populations of linear features with absolute density values of $\rho_{1}$ and $\rho_{2}$ respectively, separated from line $A^{\prime}$ by angles of $\alpha_{1}$ and $\alpha_{2}$ respectively. To find $\alpha_{1}$, we construct line $\mathrm{OP}_{1}$, normal to the trend of the first possible population of features, for which the apparent density will be $\rho_{1}$. As the angle between $\mathrm{OP}_{1}$ and $\mathrm{AA}^{\prime}$ is $\beta_{i 1}$, then the apparent density on line $\mathrm{AA}^{\prime}\left(\rho_{a}\right)$ will be:

$$
\rho_{a}=\rho_{1} \cdot \cos \beta_{1}
$$

Note that $a_{1}+\beta_{1}=90^{\circ}$. As the angle between $\mathrm{OP}_{1}$ and $\mathrm{BB}^{\prime}$ is $-\beta_{1}$, the apparent density on line BB' will be:

$$
\rho_{b}=\rho_{1} \cdot \cos \left(\phi-\beta_{1}\right)
$$

Both $\rho_{a}$ and $\rho_{b}$ are known apparent densities. Therefore

$$
\begin{aligned}
\frac{\rho_{b}}{\rho_{a}} & =\frac{\rho_{1} \cdot \cos \left(\phi-\beta_{1}\right)}{\rho_{1} \cdot \cos \beta_{1}} \\
& =\frac{\cos \phi \cdot \cos \beta_{1}+\sin \phi \cdot \sin \beta_{1}}{\cos \beta_{1}}
\end{aligned}
$$

$=\cos \phi+\sin \phi \cdot \tan \beta_{1}$

$$
\tan \beta_{1}=\frac{\frac{\rho_{b}}{\rho_{a}}-\cos \phi}{\sin \Phi}
$$

The ratio of the two apparent densities $\rho_{b} / \rho_{a}$ is referred to as the apparent 


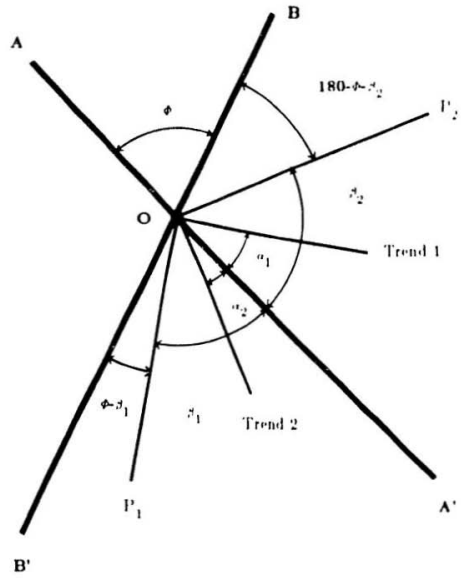

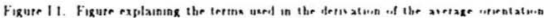

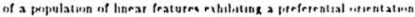


density ratio, and is replaced by the symbol $\rho$. Angle $\alpha_{1}$ will be measured from line $\mathrm{AA}^{\prime}$ in the direction of the obtuse angle. As $\beta_{1}=90^{\circ}-\alpha_{1}, \tan \beta_{1}=1 / \tan \alpha_{1}$, and

$$
\alpha_{1}=\tan ^{-1} \frac{\sin \varphi}{\rho-\cos \phi}
$$

The absolute density of the linear features, $\rho_{1}$, is found by rearranging [1]:

$$
\rho_{1}=\frac{\rho_{a}}{\sin \alpha_{1}}
$$

The second solution, $\alpha_{2}$, is found by a process similar to that used to find $\alpha_{1}$. The only difference is that $B_{2}$ is the angle between line $\mathrm{OP}_{2}$ and line $\mathrm{AA}^{\prime}$ and the angle between $\mathrm{OP}_{2}$ and $\mathrm{BB}^{\prime}$ will be $180^{\circ}-\phi-\beta_{2}$. Consequently,

$$
\begin{aligned}
\rho_{a} & =\rho_{2} \cdot \cos \beta_{2} \\
\rho_{b} & =\rho_{2} \cdot \cos \left(180^{\circ}-\left(\phi+\beta_{2}\right)\right) \\
& =-\rho_{2} \cdot \cos \left(\varphi+\beta_{2}\right)
\end{aligned}
$$

Calculating the apparent density ratio $\left(\rho_{r}=\rho_{b} / \rho_{a}\right)$, and bringing all of the known terms to the right side, we find

$$
\begin{aligned}
& \tan \beta_{2}=\frac{\rho_{r}+\cos \phi}{\sin \phi} \\
& \alpha_{2}=\tan ^{-1} \frac{\sin \phi}{\rho_{r}+\cos \phi}
\end{aligned}
$$




$$
\rho_{.2}=\frac{\rho_{0}}{\sin a_{22}}
$$

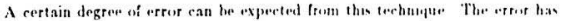

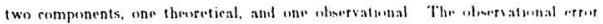

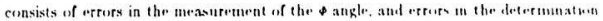

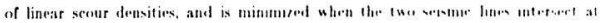

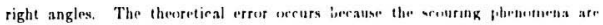

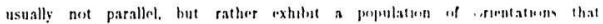

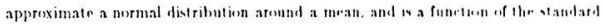

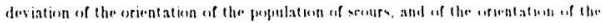
two seismie lines with respert to the mean crentatuon of the pupulation of wour

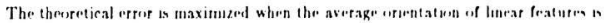
parallel to a seismic line. As the linear fentures nee net nfiolutely parallel ereral

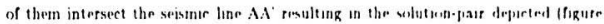

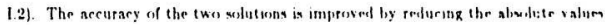

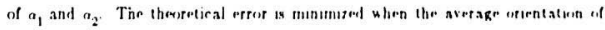

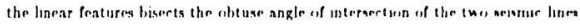

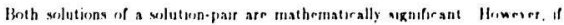
the erosional features have one dominant trend, only the of the coluturio to

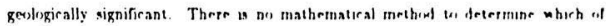

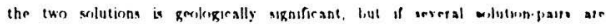

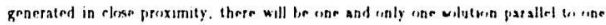
of the colutions of all of the vilutiots-pain in the group (figute I z) Sriamir lanre

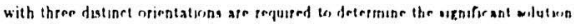




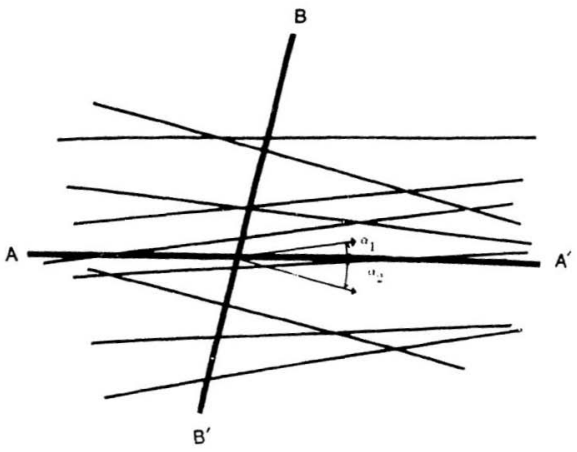

Figure 1.2. Figure showing the solution-pair derived oner a perpulation of preferentially oriented figure whe

average orientation. 


\section{Computer programs and subroutines}

A number of programs and subroutines were constructed during the writing of this thesis. All of the programs use FORTRAN 77 coute. Some of the programs are ton trivial to te listed, while others use a sperialized plotting packnge, atul it weuld be inappropriate to list them here. A number of the routiars may be usefully listrit here.

\section{A) Subroutines FRACTILE and INTEC;}

FRACTILE and INTEG; were used to eonvert normal ask values te probability axis valurs. Therefore, they were used tout enly to convert data peents to probability values, but to plot the computed curves on the firabalulity axis These routines were also called by the program which was used to find inferteen points in grain size data plotted on the probabulity axis

What these subroutine do is envert firesentage valum inter fractiles, if penbability units. Fractiles tmay be theought of in terms the nuintire of tandat.l

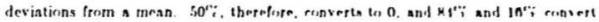

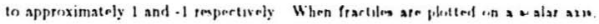

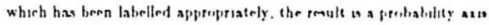

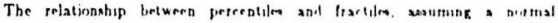
distribution as given as

$$
\mathrm{P}=\frac{1}{\sqrt{2}} \int_{-x}^{n}\left(x p\left(x-x^{2} / 2\right) d x\right.
$$

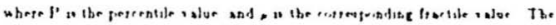


purpose of subroutine FRACTILE is, therefore, to estimate the value of $\mu$ for each input value of $\mathrm{P}$. The subroutine is designed to work for $0.06 \% \leq P \leq 89.94 \%$. Although $\mu$ cannot be directly calculated from $\mathrm{P}, \mathrm{P}$ can be calculated from $\mu$, so the subroutine successively estimates values of $\mu$ until the corresponding value of $\mathrm{P}$ is sufficiently close $(0.05 \%)$ to the input value of $\mathbf{P}$. The corresponding values of $\mathrm{P}$ are calculated by the subroutine INTEG.

\section{B) Subroutine POLHRES}

POLHRES calculates the grain-size curve on a probability axis which results from the mixing of NCOM log-normal components, where the value of NCOM is defined in the calling program. This subroutine therefore requires FRACTIE and INTEG. The points of the resultant grain-size curve are spaced at a distance of $1 / 10 \Phi$.

\section{C) Program INFLECT}

This program was used to find inflection points in cumulative grain-size data plotted on a probability axis. Finding the inflection points is necessary to dissect grain-size curves using Harding's (1049) graphical technique. Because the program is likely to pick inflection points along flat portions of the curve, it is helpful to estimate the location of the inflection points from the curve before running the program.

\section{D) Program PLOTPREP}

This program was used to prepare grain-size data for plotting on the 
probability axis. The program acts as a "geologist's assistant". The author did not have time to develop software that would dissect grain-size curves. Instead, curves were dissected using a graphical technique similar to that of Harding (1849), which was used as a first estimate. The resultant curve was compared numerically to the data, and the characteristics of the different log-normal components were modified manually to improve the fit.

The program is designed to accept up to five log-normal curves. If more are desired, some of the variable arrays will have to be increased in size. Those arrays affected are $\mathrm{P}(5), \operatorname{MEAN}(5)$, STAN(5), and PL(5,39). 


\section{SUBROUTINE FRACTILE(P)}

C SUBROUTINE TO CONVERT CUSULATIVE PROBABIIITIES TO FRACTILES

C READ GRAIH SIZE (PHI UNITS) AHD CUMULATIVE PERCEYTAGE

c

5 READ (2,1) PHI, P

1 FORMAT (1X, 2F9. 2)

$P=P / 100.0$

IF (P.GE. 0. 9994) GOTO 3000

IF (P.GE. 0. 998) GOTO 998

IF (P.GE. 0.99) GOTO 99

IF (P.GE. 0.985) GOTO 985

IF (P. GE. O. 97) GOTO 97

IF (P.GE. 0.93) GOTO 93

IF (P.GE. 0.88) GOTO 88

IF (P.GE. O.82) GOTO 82

IF (P.GE. 0.70) GOTO 70

IF (P. GE. 0. E9) GOTO 59

IF (P.GE.0. 53) GOTO 63

IF(P.GE.0.50) GOTO 50

IF (P.GE. 0.47) GOTO 47

IF (P.GE.0.41) GOTO 41

IF (P.GE.0.30) GOTO 30

IF (P.GE.0.18) GOTO 18

IF (P.GE.0.12) GOTO 12

IF (P. GE. 0.07) GOTO 7

IF (P.GE. 0.03) GOTO 3

IF (P.GE.0.015) GOTO 15

IF (P.GE. 0.002) GOTO 102

IF (P.GE. 0.0006) GOTO 108

GOTO 5

c

C INITIALIZE VALUES FOR EACH OF THE POTENTIAL RANGES TN

C PERCENT VALUES

C

998 UBASE $=2.912$

UTOP $=3.615$

PBASE $=0.998$

PTOP=0. 9994

GOTO 1000

99 UBASE $=2.3337$

UTOP=2.912

PEASE $=0.99$

PTOP $=0.998$

GOTO 100 n 
985 UBASE $=2.175$

UTOP=2.3337

$\mathrm{PBASE}=0.985$

PTOP=0.99

GOTO 1000

97 UBASE $=1.8835$

UTOP=2.176

$P B A S E=0.97$

PTOP $=0.985$

GOTO 1000

93 UBASE $=1.477$

UTOP $=1.8835$

$\mathrm{PBASE}=0.93$

$\mathrm{PTOP}=0.97$

GOTO 1000

88 UBASE $=1.1755$

UTOP $=1.477$

PBASE $=0.88$

PTOP $=0.93$

GOTO 1000

82 UBASE $=0.9155$

UTOP=1.1755

PBASE $=0.82$

PTOP $=0.88$

GOTO 1000

70 UBASE $=0.5245$

UTOP $=0.9165$

PBASE $=0.70$

PTOP $=0.82$

GOTO 1000

69 UBASE $=0.2275$

UTOP $=0.5245$

$\mathrm{PBASE}=0.69$

PTOP $=0.70$

GOTO 1000

63 UBASE $=0.0765$

UTOP $=0.2275$

$\mathrm{PBASE}=0.63$

PTOP $=0.69$

COTO 1000

50 UBASE $=0.0$

UTOP $=0.25$

PBASE $=0.6$

PTOP $=0.6$

GoT0 1000 
47 UBASE $=-0.0755$

$U T O P=0.00$

PBASE $=0.47$

$\mathrm{PTOP}=0.50$

GOTO 1000

41 UBASE $=-0.2275$

UTOP $=-0.0755$

PBASE $=0.41$

$P T O P=0.47$

GOTO 1000

30 UBASE $=-0.6245$

UTOP $=-0.2275$

PBASE $=0.30$

PTOP $=0.41$

GOTO 1000

18 UBASE $=-0.9156$

UTOP $=-0.5245$

PBASE $=0.18$

PTOP $=0.30$

GOTO 1000

12 UBASE $=-1.1765$

UTOP $=-0.9155$

PBASE $=0.12$

PTOP $=0.18$

COTO 1000

7 UBASE $=-1.477$

UTOP $=-1.1755$

PBASE $=0.07$

$P T O P=0.12$

GOTO 1000

3 UBASE $=-1.8835$

UTOP $=-1.477$

PBASE $=0.03$

$\mathrm{PTOP}=0.07$

GOTO 1000

15 UBASE $=-2.176$

UTOP $=-1.8835$

$\mathrm{PBASE}=0.015$

PTOP $=0.03$

GOTO 1000

102 UBASE $=-2.912$

UTOP $=-2.175$

PBASE $=0.002$

PTOP $=0.015$

GOTO 1000 


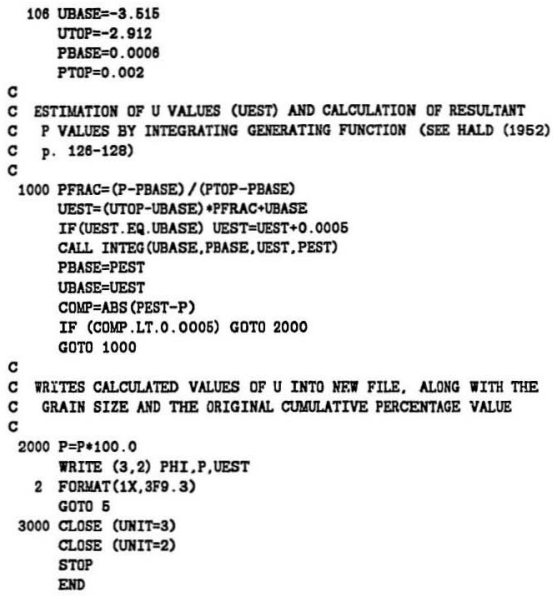


SUBROUTINE INTEG (UBASE, PBASE, UBST, PEST)

C

C INTEGRATION SUBROUTINE

C CALCULATES PEST VALUES USING ESTTUATED U VALUES

C BY SUI OF TRAPEZOIDS NETHOD

C

DIUTYSION H(6000)

SUN $=0.0$

COUNT $=($ UEST - UBASE $) * 2000.0$

$N=\operatorname{IFIX~(ABS~(COUNT))~}+1$

DO $5 \mathrm{I}=1, \mathrm{~N}$

FI=FLOAT(I)

IF (UBASE. GT. UEST) GOTO 20

$H(I)=\operatorname{EXP}(-0.5 *(U B A S E+0.0005 * F I) * * 2)$

GOTO 15

$20 \quad H(I)=\operatorname{EXP}(-0.5 *(U E S T+0.0005 * F I) * 2)$

$15 \mathrm{SUM}=\mathrm{SUM}+\mathrm{H}(\mathrm{I})$

5 CONTINUE

SUM $=$ SUM $-H(1) / 2.0-H(N) / 2.0$

SUMV $=\operatorname{SUM} * 0.0005 / \operatorname{SQRT}(8.0 * \operatorname{ATAN}(1.0))$

$L=1$

IF (UBASE. GT. UEST) $\mathrm{L}=-1$

PEST=PBASE+SUM $* 1$

RETURN

EYD 
SUBROUTINE POLHRES (NCOM,P.MEN, STAN)

CHARACTER*15 AMA

REAL VEAN (NCOM)

DIMENSION PHI (120), P(NCOM), STAN (NCOM), PL $(5,120)$

TRITE $(6,11)$

11 FORMAT (1X, 'NAME OF OUTPUT FILE?')

READ $(5, *)$ MAA

OPEH (UNIT =3, FILE $=A M A$, TYPE $=$ 'NEF')

DO $10 I=1, N C O N$

$10 \operatorname{VRITE}(3,61) P(I), \operatorname{MEAN}(I), \operatorname{STAN}(I)$

c

C USING TKE INPUT PARAMETERS OF THE COLAFONENT LOG-

C NORMAL CURVES, THE COMPONENT POPULATIONS AND

C THE RESULTING CURVES ARE PLOTTED.

c

130 DO $50 \quad I=1,120$

40 PHI (I) $=0.1 *$ FLOAT (I) -1.0

DO $45 \mathrm{~J}=1$, NCOM

$45 \mathrm{PL}(\mathrm{J}, \mathrm{I})=(\operatorname{PHI}(\mathrm{I})-\operatorname{MEAN}(\mathrm{J})) / \operatorname{STAH}(\mathrm{J})$

SO CONTINUE

c

C CALCULATION OF COMPOSITE LINE-TO BE PLOTTED BETWEEN

C -1.0 AND 11.0 PHI UNITS, DEFINED BY TEN POINTS PER

C PHI UNITS.

c

DO $100 \quad I=1,120$

COYP $=0.0$

DO $95 \mathrm{~J}=1$, KCOM

$C=A B S(P L(J, I))$

IF (G.GE. 3.6) THEN

$P R C=1.0$

GOTO 85

ENDIF

CALL INTEG $(0,0,0.6, C, P R C)$

$65 \operatorname{IF}(\mathrm{PL}(J, I), L T, 0.0) \quad P R C=1,0-P R C$

$95 \operatorname{COMP}=\operatorname{COMP}+\mathrm{P}(\mathrm{J}) * \mathrm{PRC}$

COM=COMP

CALL FRACTTLE (COLP)

COM $=$ COM $* 100.0$

WRITE (3,61) PHI (I), COY, COMP

61 FORMAT (1X, 3F9.3)

100 CONTINUE

RETURN

END 
$c$

c

c

c

C

c

c

CHARACTER*13 AMA

DIMENSION PHI (25), PER (25), FRAC (25), DF1 (25)

DIMENSION DF2(25), FLEC(25)

VRITE $(6,111)$

111 FORUAT(1X, 'FROM WHAT FILE IS DATA READ?')

C

C DATA IS TO BE READ FROM FILE FRACXExx. DAT

C ENTER THE NULBER OF DATA POINTS IN THE FILE WHEN PROMPTED.

c

READ (5,*) AMA

OPEN (UNIT $=2$, FILE = AAR, TYPE=' $O L . D^{\prime}$ )

WRITE $(6,112)$

112 FORMAT(1X, 'HOW MANY DATA POINTS?')

READ $(5, *)$ NPTS

DO 5 I $=1$, NPTS

$6 \operatorname{READ}(2,2)$ PHI (I) , $\operatorname{PER}(I), \operatorname{FRAC}(I)$

2 FORMAT (1X, 3F9.2)

$I=$ NPTS

C

C

C

10 DO $15 \mathrm{~L}=1, \mathrm{I}-1$

15 DF1 $(L)=F R A C(L+1)-F R A C(L)$

DO $20 \mathrm{~L}=2, \mathrm{I}-1$

20 DF2 $(L)=D F 1(L)-D F 1(L-1)$

DF2 (1) $=-1.0$

DF2 (I) $=1.0$

C

C THE FOLLONING PROCEDURE DETERMINES UHEN SUCCESSIVE VALUES

C OF DF2 HAVE OPPOSITE SIGN, OR WHEH ONE OF THE DF2

C VALUE IS EqUAL TO ZERO. EACH POTENTIAL INFLEGTION

C POINT IS RECORDED. BAD DATA POINTS MAY CAUSE

C APPARENT INFLECTION EVENTS, THUS EACH OF THE ' $N$ '

C INFLECTION POINTS SHOULD BE CHECKED

C

$N=0$

DO $25 L=2, I-2$ 


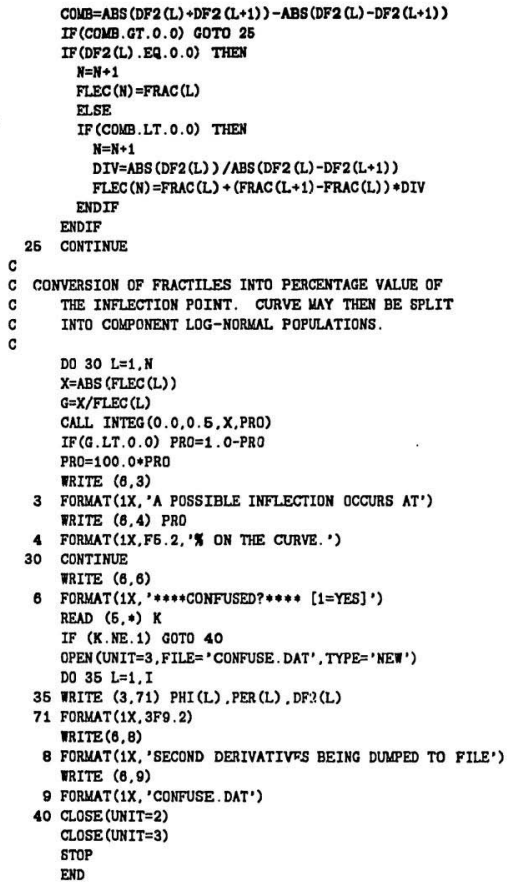




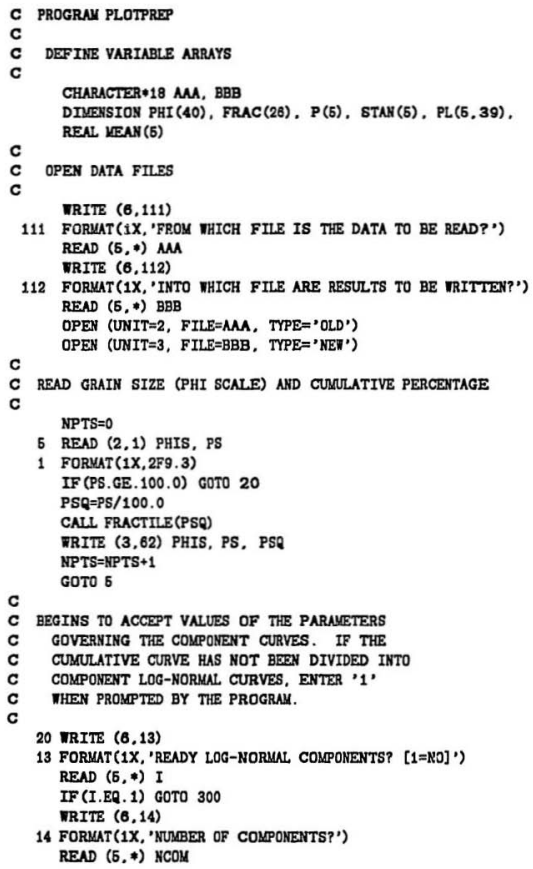




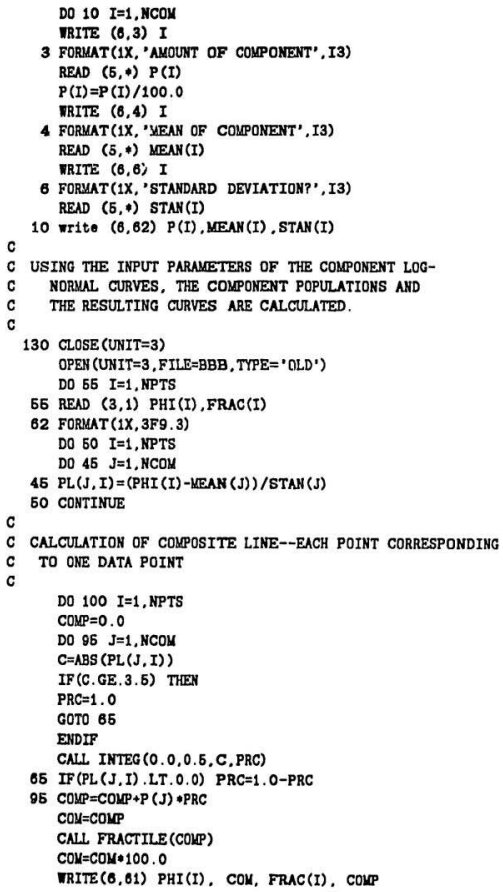




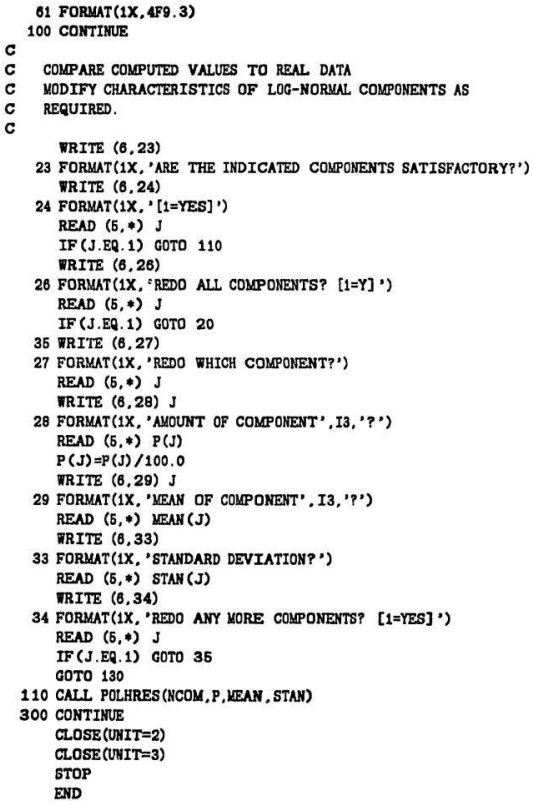




\section{Seismic lines over core sites}

Sixteen piston cores can be located on seismic lines. Three piston cores were not collected on seismic lines, but lines near these core sites are displayed (figure III.1). 

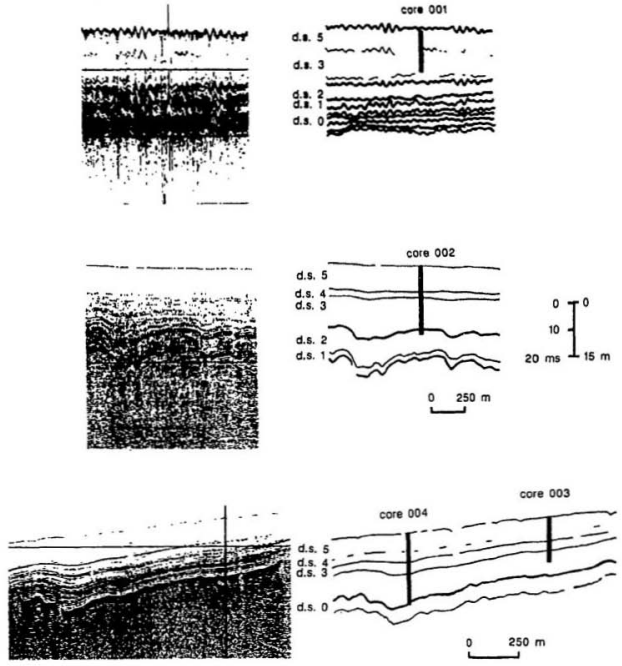

Figure IIl.1. Core-seismic correlations for cores (i) 83-012-001. (ii) 87-003-002, and (iii) 87-003-003 and 87-003-004. Vertical seale is constant for all cores. 

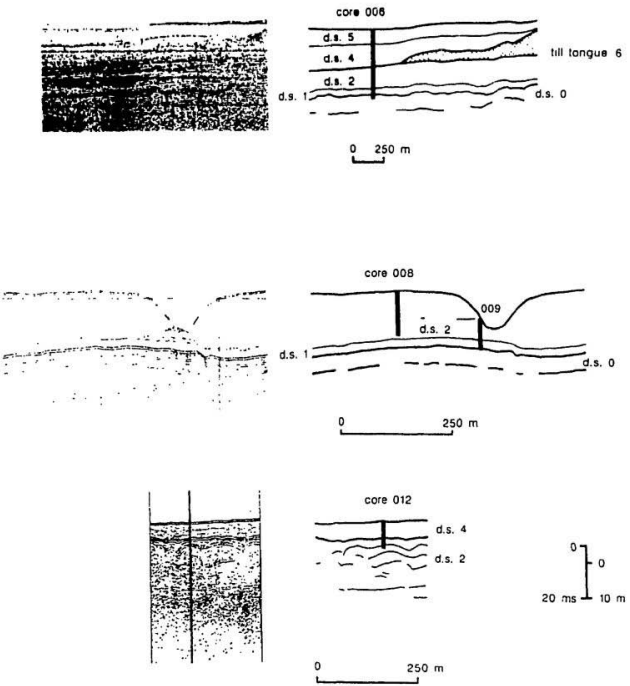

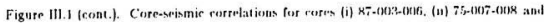

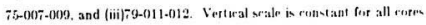



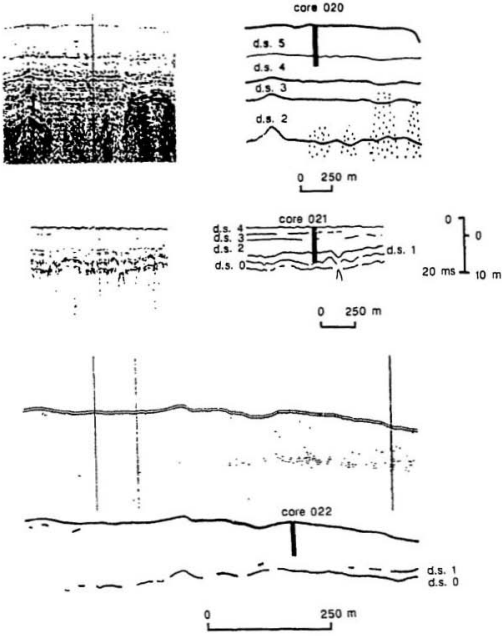

Figure III.1 (cont.). Core-seismic correlations for cores (i) $77-002-020$, (ii) 86-034-021, and (iii) 86-034-022. Vertical scale is constant for all cores. 

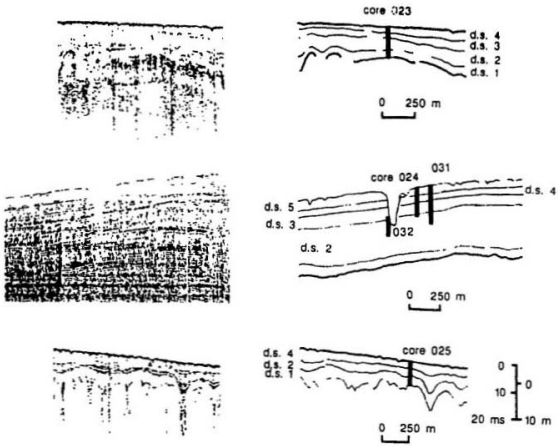

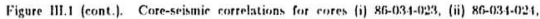
86-034-031, and 86-034-032, and (iii) 86-034-025, 

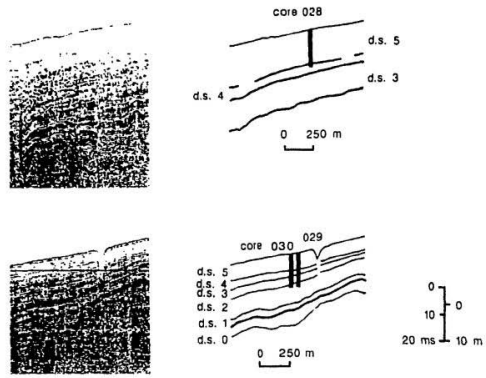

Figure III.1 (cont.). Core-seismic correlations for cores (i) 86-034-028, (ii) 86-034-029 and 86-034-030. 


\section{Dissected cumulative grain-size curves}

Additional dissected grain-size curves are presented (figure IV.1). 
Figure IV.1. Dissected cumulative grain-size curves.
a) $0.12 \times(2.96 \Phi \pm 0.57 \Phi)+0.02 \times\left(6.04 \Phi_{ \pm} 0.48 \Phi\right)+0.86 \times\left(7.50 \Phi_{ \pm} 1.70 \Phi\right)$
b) $0.38 \times\left(3.32 \Phi_{ \pm} 0.84 \Phi\right)+0.10 \times\left(6.00 \Phi_{ \pm} 0.55 \Phi\right)+0.52 \times\left(7.90 \Phi_{ \pm 1.58}\right)$
c) $0.12 \times\left(3.12 \Phi_{ \pm} 0.51 \Phi\right)+0.05 \times\left(6.36 \Phi_{ \pm} 0.55 \Phi\right)+0.84 \times\left(7.41 \Phi_{ \pm 1.76 \Phi)}\right.$
d) $0.10 \times(3.70 \phi \pm 0.54 \Phi)+0.07 \times(5.80 \Phi \pm 0.54 \phi)+0.83 \times\left(7.62 \Phi_{ \pm 1.69}\right)$
e) $0.09 \times(3.35 \Phi \pm 0.65 \Phi)+0.57 \times\left(4.59 \Phi_{ \pm} .24 \Phi\right)+0.34 \times\left(8.30 \Phi_{ \pm 1.30}\right)$
1) $0.09 \times\left(3.74 \Phi_{ \pm} 0.49 \phi\right)+0.50 \times(4.08 \phi \pm 1.39 \phi)+0.41 \times(7.90 \Phi \pm 1.30 \Phi)$ 

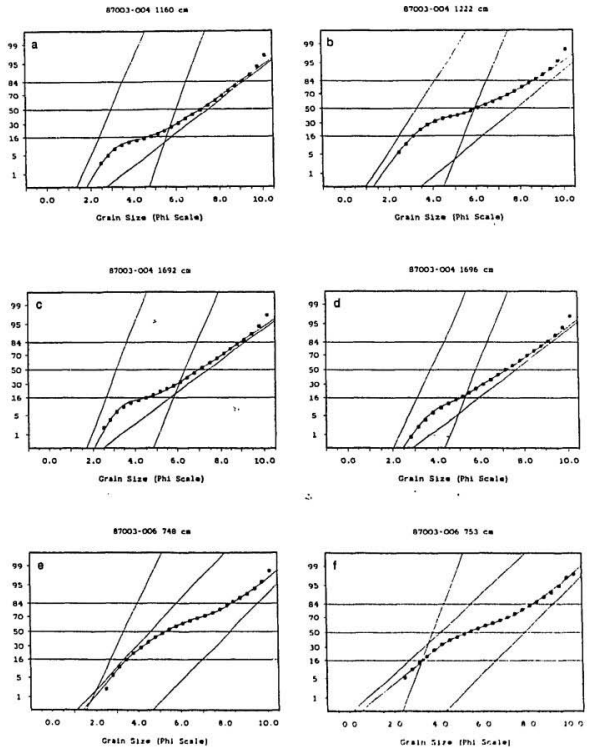
Figure IV.1 (cont.). Dissected cumulative grain-size curves.

a) $0.15 \times(3.85 \phi \pm 0.43 \phi)+0.44 \times(4.63 \phi \pm 1.26 \phi)+0.41 \times\left(8.15 \phi_{ \pm 1} .45 \phi\right)$

b) $0.30 \times(3.79 \phi \pm 0.32 \phi)+0.39 \times(4.94 \phi \pm 1.15 \phi)+0.31 \times(8.17 \phi \pm 1.30 \phi)$

c) $0.14 \times(3.88 \phi \pm 0.50 \phi)+0.54 \times(4.74 \phi \pm 1.48 \phi)+0.32 \times(8.04 \phi \pm 1.50 \phi)$

d) $0.11 \times(4.15 \phi \pm 0.28 \phi)+0.61 \times(5.44 \phi \pm 1.35 \phi)+0.28 \times(8.49 \phi \pm 1.30 \phi)$

e) $0.14 \times(4.02 \Phi \pm 0.20 \Phi)+0.71 \times(4.97 \Phi \pm 1.35 \Phi)+0.15 \times(8.63 \Phi \pm 1.17 \Phi)$

f) $0.27 \times(4.20 \phi \pm 0.37 \phi)+0.50 \times(5.32 \Phi \pm 1.41 \varphi)+0.23 \times\left(8.65 \Phi_{ \pm 1.22} \phi\right)$ 

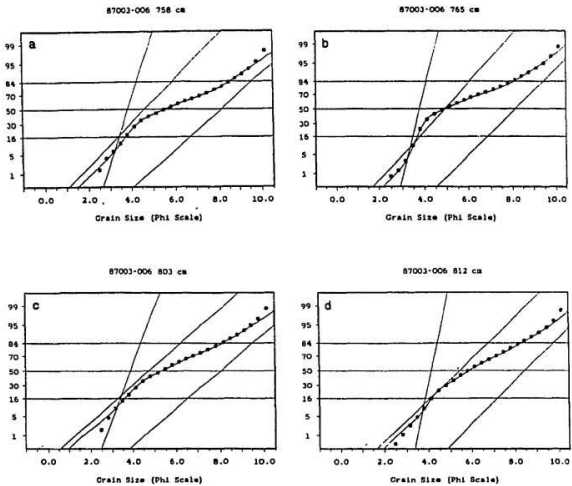

07003-006 910 c:
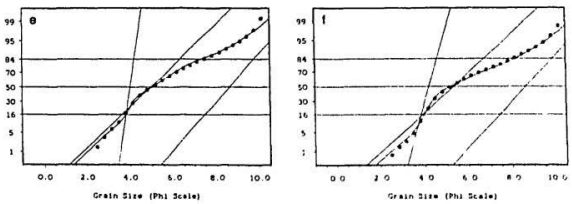


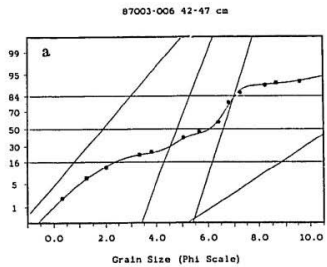

87003-006 820-830 ct

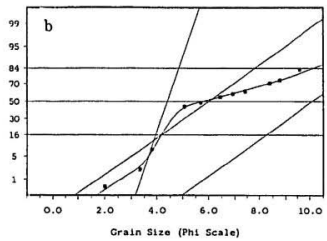

Figure IV.1 (cont.).

a) $0.24 \times(1.89 \Phi \pm 1.11 \phi)+0.21 \times(4.80 \Phi \pm 0.50 \phi)+0.45 \times(6.58 \Phi \pm 0.42 \Phi)+$ $0.10 \times\left(10.84 \Phi_{ \pm} .01 \Phi\right)$

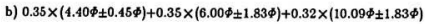




